\title{
Early Cretaceous
}

(Albian) Ammonites

From the Chitina

Valley and Talkeetna

Mountains, Alaska

GEOLOGICAL SURVEY PROFESSIONAL PAPER 354-D

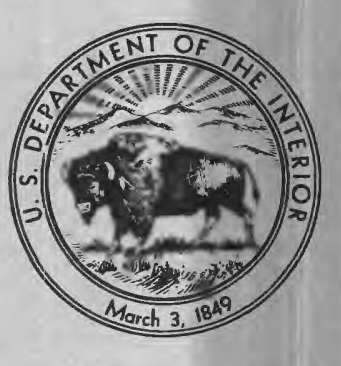




\section{Early Cretaceous}

(Albian) Ammonites

From the Chitina

Valley and Talkeetna

Mountains, Alaska

By RALPH W. IMLAY

SHORTER CONTRIBUTIONS TO GENERAL GEOLOGY

GEOLOGICAL SURVEY PROFESSIONAL PAPER 354-D

The Early Cretaceous (Albian) ammonites in southern Alaska have strong affinities with those in California and Oregon but are in part of Boreal and Eurasian origin

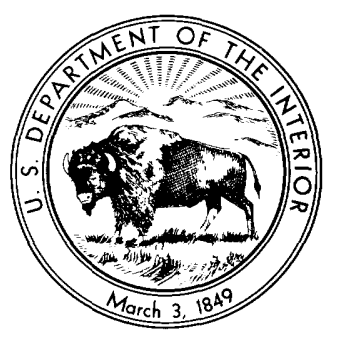




\section{UNITED STATES DEPARTMENT OF THE INTERIOR \\ FRED A. SEATON, Secretary \\ GEOLOGIGAL SURVEY}

Thomas B. Nolan, Director

For sale by the Superintendent of Documents, U.S. Government Printing Office Washington 25, D.C. - Price 50 cents (paper cover) 


\section{CONTENTS}

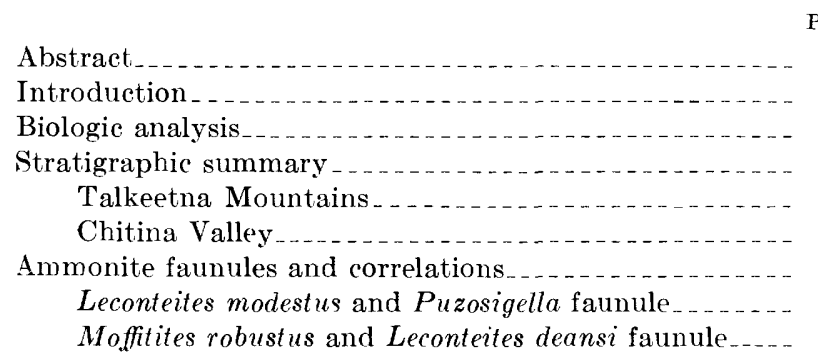

Page
87
87
87
88
88
88
89
89
91

Ammonite faunules and correlations-Continued

Bievericeras breweri and $B$. cf. B. hulenense faunule..

Freboldiceras singulare faunule.................

Other Albian faunules. ..............................

Comparisons with other faunas. . .

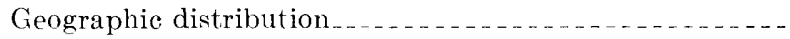

Summary of results

Systematic descriptions

References............................................

Index _ . . . . . . .

Page

\section{ILLUSTRATIONS}

[Plates follow index]

Plate 11. Phyllopachyceras, Calliphylloceras, Anagaudryceras, Valdedorsella?, and Hypophylloceras.

12. Callizoniceras, Kossmatella, Ptychoceras, and Tetragonites.

13. Moffitites.

14. Beudanticeras, Moffitites, and Freboldiceras.

15. Kennicottia.

16. Puzosia and Beudanticeras.

17. Desmoceras? and Brewericeras.

18. Parasilesites, Hulenites, Arcthoplites?, and Lemuroceras.

19. Leconteites, Aucellina, Puzosigella, and Cleoniceras.

Figure 21. Correlation of the Albian faunas of the Chitina Valley and Talkeetna Mountains

22. Index map of the principal areas $\ldots$

23. Index map showing Albian localities in the Chitina Valley $\ldots$

24. Index map showing Albian localities in the Talkeetna Mountains

Page 90 94 95

\section{TABLES}

TABLE 1. Ammonite genera in the Albian beds of the Chitina Valley, Talkeetna Mountains, Alaska, showing biological relationships and relative numbers available for study $\ldots$

2. Localities at which ammonites were collected from the Albian strata of the Chitina Valley and Talkeetna Mountains.

3. Geographic distribution of early and middle Albian ammonites from the Chitina Valley and Talkeetna Mountains, Alaska. 


\title{
EARLY GRETACEOUS (ALBIAN) AMMONITES FROM THE CHITINA VALLEY AND TALKEETNA MOUNTAINS, ALASKA
}

\author{
By RaLph W. TMLiY
}

\begin{abstract}
The Early Cretaceous (Albian) ammonites of the Chitina Valley and Talkeetna Mountains, Alaska, belong to four faunules ranging in age from early to early middle Albian.

The lowest faunule in the Chitina Valley is characterized by Leconteites modestus (Anderson) and by species of Puzosigella that pernit a close correlation with the Leconteites lerontei zone of California and Oregon and hence with the early Albian of Eurasia. Moffitites crassus Imlay, n. sp., also may be characteristic of this faunule.

The next higher faunule in the Chitina Valley is characterized by Moffitites robustus Imlay and Leconteites deansi (Whiteaves). It is probably only slightly younger than the Lcconteites lecontei zone of California and Oregon. The next higher Albian faunule in the Chitina Valley is characterized by a coarsely ribbed variant of Brevericeras breveri (Gabb) that suggests approximate correlation with the Brevericeras hulenense zone in California. An early Albian age for this faunule is indicated by the ammonites Taldedorsella, Parasilesites, and subgenus subarcthoplites.
\end{abstract}

In the Talkeetna Mountains the only Albian representative is the Freboldiceras singulare faunule, which is characterized by excellently preserved specimens of Beudanticeras glabrum (Whiteaves), Freboldiceras singulare Imlay, and Lemuroceras talkeetnanum Imlay, n. sp. These are either identical with or closely related to ammonites in the western interior of Canada beneath beds that contain Gastroplites. The faunule is probably younger than the Lemuroceras belli zone of Canada and the Brewericeras breweri faunule of the Chitina Valley, but the evidence is not conclusive. If it is younger, its age is probably early middle Albian.

The Albian ammonite faunules of the Chitina Valley have a provincial aspect owing to the presence of genera not yet found outside the Pacific coast of North America. These include Moffitites, Kennicottia, Brewericeras, Leconteites, Puzosigella. Hulenites, and Parasilesites. A marine connection with the boreal province through Canada or Alaska is indicated, however, by the presence of such ammonites as Lemuroceras ( $S u b$ arcthoplites) and Callizoniceras. In addition the faunules include many genera that are distributed nearly worldwide, or that do not characterize any particular province. The Albian ammonites of the Talkeetna Mountains likewise exhibit a provincial aspect, but in contrast to those from the Chitina Valley, the relationships are strong with the western interior of Canada and with northern Alaska.
These faunal relationships imply that the Albian sea that covered southern Alaska had broad connections with seas in the western interior of the continent, in California and Oregon, and in Asia.

\section{INTRODUCTION}

This study of the Early Cretaceous (Albian) ammonites of the Chitina Valley and Talkeetna Mountains in the southeastern part of the main body of Alaska is based on collections made by members of the Geological Survey since 1899. Thanks are due to Leo G. Hertlein and Dallas G. Hamna, of the California Academy of Sciences in San Francisco, for the privilege of examining the type specimens of certain Albian ammonites. Correlations with Albian beds in California were influenced by discussions with Michael Murphy of the University of California at Riverside. Some notes on the Cretaceous of the Chitina Valley prepared by Don .J. Miller, of the U.S. Geological Survey, were very useful in determining the stratigraphic distribution of the Albian faumules.

The Albian ammonites of the Chitina Valley and Talkeetna Mountains are of exceptional interest because they are highly raried, and well preserved and represent an association of ammonites that occur elsewhere in distinct faunal provinces and are associated with plants that paleobotanists maintain are of Jurassic age. Description of the ammonites is justified, therefore, as documentation of their Albian age and that of the associated plants, as an aid in geologic mapping, and as a means of interpreting local geologic history in terms of events elsewhere. The fact that the ammonite faunules are derived from various provinces should prove useful in making interregional and intercontinental correlations.

\section{BIOLOGIC ANALYSIS}

The Albian ammonites from the Chitina Valley and Talkeetna Mountains include 379 specimens, of which 308 are specifically identified and 61 are compared to 
described species. Among these the Phylloceratidae are represented by 28 , the Tetragonitidae by 40 , the Ptychoceratidae by 2, the Desmoceratidae by 205 , the Silesitidae by 5 , the Kossmaticeratidae by 4 , and the Hoplitidae by 95 . The distribution of these specimens by genera, subfamilies, and families is shown in table 1 .

The table shows that the Desmoceratidae is the dominant family as regards individuals, species, and genera. It is characterized by the presence of such genera as Moffitites, Freboldiceras, Kennicottia, and Brewericeras, which have not been recorded outside the $\mathrm{Pa}$ cific coast of North America. It includes, however, such Old World genera as Taldedorsella, Callizoniceras, Puzosia, and Desmoceras. The species of Beudanticeras present have certain peculiarities that distinguish them from European species, but are judged not to be of sufficient importance to warrant generic differentiation.

TABLE 1.-Ammonite genera in the Albian beds of the Chitina Talley and Talkeetna Mountains, Alaska, showing biological relationships and relative numbers a'ailable for study

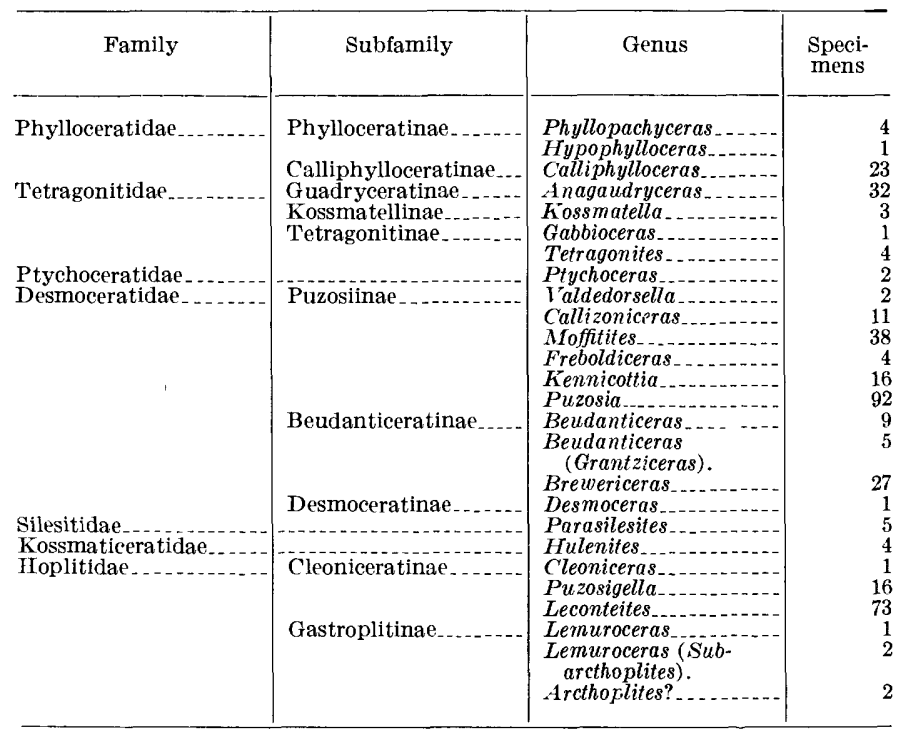

Next in importance is the family Hoplitidae in which the genera Puzosigella and Leconteites dominate in individuals and in species. These genera have not yet been reported elsewhere than the Pacific coast of North America. Of particular importance is the presence of typical representatives of the genera Cleoniceras and Lemuroceras. There are also, two specimens belonging to Subarcthoplites Casey $(1954$, p. 111) which is herein considered to be a subgenus of Lemuroceras.

The families Phylloceratidae and Tetragonitidae are of comparatively minor importance, and the other families in table 1 are represented only by single species and a few specimens. It is interesting, however, that
Parasilesites and Hulenites have not been recorded outside the Pacific coast of North America.

The absence of Pseudoleymeriella Casey (1957, p. 35 ; Whiteaves, 1893b, p. 444, pl. 7, figs. 2, 2a, b), which occurs in early Albian beds in the Queen Charlotte Islands, as well as the absence of Douvilleiceras, which is common in California, possibly reflects insufficient collecting.

\section{STRATIGRAPHIC SUMMARY}

\section{TALKEETNA MOUNTAINS}

Albian ammonites have been found in the Talkeetna Mountains at only two places, one near the head of Billy Creek and the other near the head of Flume Creek. They occur in concretions in the basal 125 feet of a shale and siltstone unit above 150 feet of sandstone that contains coaly beds of unknown age. This sandstone overlies 550 feet of sandstone of Valanginian age that overlies the Nelchina limestone of Valanginian age. From the siltstone 250 feet above the concretions, specimens of Inoceramus of Late Cretaceous age have been obtained. There is a possibility that the concretions have been reworked from older beds (Arthur Grantz, written communication, Dec. 29, 1958). Nevertheless, the presence of Albian ammonites, even locally, in the Talkeetna Mountains suggests that Albian beds once existed nearby and may now exist in the subsurface of the Copper River basin east of the mountains.

\section{CHITINA VALLEY}

Albian beds in the Chitina Valley have been identified only in the upper (eastern) 50 to 60 miles of the valley east of the Kuskulana River. The main areas of outcrop, from west to east, occur near Kuskulana Pass, along Fohlin and Bear Creeks west of Kennicott Glacier, near the head of McCarthy Creek, and near the foot of Nizina Glacier. Several other areas of outcrop occur from 25 to 35 miles south of the Nizina Glacier near the headwaters of Young Creek and near the mouth of Canyon Creek. The extent of outcrop in most of these areas is not known. However, the numerous collections obtained near Kuskulana Pass and the creeks immediately to the west are all of Albian age except for some fossils obtained 5,800 feet $\mathrm{S}$. $39^{\circ} \mathrm{E}$. of the mouth of Slatka Creek (Mes. loc. 8939) that are probably of Late Cretaceous age. In the area along Fohlin and Bear Creeks, all the Albian fossils were obtained near or north of Bear Creek and its east-northeast projection.

The total thickness of the Albian beds in the Chitina Valley is not known, but it is probably only a few hundred feet. In the section measured by Moffit (1938, 
p. 71) on Fourth of July Creek west of Kennicott Glacier, only the lower 150 to 250 feet of massive brown sandstone and crumbly gray shale have furnished Albian fossils. The thickness of Albian beds at the head of McCarthy Creek must be slight also because that area has furnished many collections of Late Jurassic (Oxfordian to Kimmeridgian) age (USGS Mes. locs. 11373, 11374, 11376, 11378, 11380, 14032, 14034, 14035, 14495-14497) and Early Cretaceous (Valanginian) age (USGS Mes. locs. 2172, 2209, 11375, 11377, 14031, 14500-14502), but only one collection (USGS Mes. loc. 6313) of Albian age. That collection was from a sandstone, but the preservation of the fossils indicates that they were obtained from a concretion in the sandstone. A collection at the bend of Young Creek (Mes. loc. 9492), obtained from concretions in brown sandstone, is younger than any of those obtained on Fohlin Creek, Bear Creek, or near Kuskulana Pass, but the thickness of the stratigraphic unit involved is not known.

The 352 feet of sandstone and shale exposed at the base of the Cretaceous near the mouth of Canyon Creek (Moffit, 1938, p. 73) (Mes. locs. 9481, 94859487) contains fossils of late Albian to Cenomanian ages, according to Tatsuro Matsumoto (1959, p. 85, $86)$, and are therefore appreciably younger than the early Albian beds exposed in a similar appearing sequence at the base of the Cretaceous on Fourth of $\mathrm{Jul}_{\mathrm{y}}$ Creek. Interestingly, Mesozoic locality 9489, about 3 miles west of the mouth of Canyon Creek, contains early Albian fossils identical with those near the base of the Cretaceous on Fourth of July, Bear, and Fohlin Creeks. Judging from published illustrations (Moffit, 1938, pl. 2; Moffit and Overbeck, 1918, fig. 2, on p. 27, and pl. 3), Mesozoic locality 9489 should be somewhat lower stratigraphically than locality 9487 at the mouth of Canyon Creek along the same belt of outcrops, but the stratigraphic interval between these localities cannot be measured from the map. These occurrences suggest, howerer, that the basal beds of the Cretaceous sequence in the Chitina Valley are of different ages from place to place and that the Albian part of the sequence is not rery thick.

\section{AMMONITE FAUNULES AND CORRELATIONS \\ LECONTEITES MODESTUS AND PUZOSIGELLA FAUNULE}

This faunule (fig. 21) is represented in the Chitina Valley near Bear, Fohlin, and Fourth of July Creeks at USGS Mesozoic localities 8877, 9971, 11389, and 14468 by the ammonites Leconteites modestus (Anderson), Puzosigella cf. P. rogersi (Hall and Ambrose), $P$. cf. $P$. perrinsmithi (Anderson), $P$. cf. $P$. taffi
(Anderson), and Anagaudryceras aurarium (Anderson). The faunule may be represented, also, by Moffitites crussus Imlay, 11. sp., obtained 1 mile north of Bear Creek at USGS Mesozoic locality 14487 and $3 \frac{1}{2}$ miles southeast of Kuskulana Pass at USGS Mesozoic locality 14477 .

These ammonites are usually associated with many specimens of the pelecypod Aucellina (Moffit, 1938, pl. 10, figs. 4,5$)$, which genus in reports dealing with the Chitina Valley has generally been compared with "Aucella" pallasi (Keyserling), or "Aucella" crassicollix (Keyserling) (Martin, 1926, p. 336, 347, 348; Moffit, 1938, tahle facing p. 80). It includes all specimens previously assigned to "Aucella" except those from the Late Jurassic and Early Cretaceous (Valanginian) localities listed herein under the heading "Stratigraphic summary."

The localities listed under the Leconteites modestus faunule are all near the contact of Cretaceous with Triassic rocks and, judging from Moffit's map (1938, pl. 2), are distinctly lower stratigraphically than most of those of the succeeding faunule typified by Moffitites robustus Imlay. At a few places, however, the fossils of one faumule were found near those of the other, as at USGS Mesozoic localities 8877 and 8878. This is not surprising considering that the total thickness of beds inrolved in both faunules is not more than 300 feet in most places (Moffit, 1938, p. 71, 78).

The beds containing Leconteites modestus (Anderson) and Pusosigella spp. may be correlated with the Leconteites Tecontei zone (Murphy, 1956, p. 2118, fig. 6 ) in California and Oregon because of the presence of the genera Leconteites and Puzosigella and of the species Leconteites modestus (Anderson). Also, the presence of Amagaudryceras aurarizm (Anderson) is normal in that zone, although it ranges higher in California into the zone of Brewericeras hulenense.

The age of the Leconteites lecontei zone is either early or early middle Albian as shown by the presence of the ammonite Dourilleiceras, which in Europe ranges from the upper part of the Leymeriella tardefurcata zone into the middle of the Hoplites dentatus zone (Spath, 1930), p. 60-65; Collignon, 1949, p. 110114; Breistroffer, 1947, p. 27, 28). An early Albian age for the Leconteites Tecontei zone is favored, however, by the presence of sitesites, which normally occurs in beds older than Albian, and by the presence of Donvilleireras in the next two overlying zones, which may be correlated with the upper part of the range of the genus in Europe. The presence of Anagaudryceras and Tetrugonites indicates an age not older than Albian. 
SHORTER CONTRIBUTIONS TO GENERAL GEOLOGY

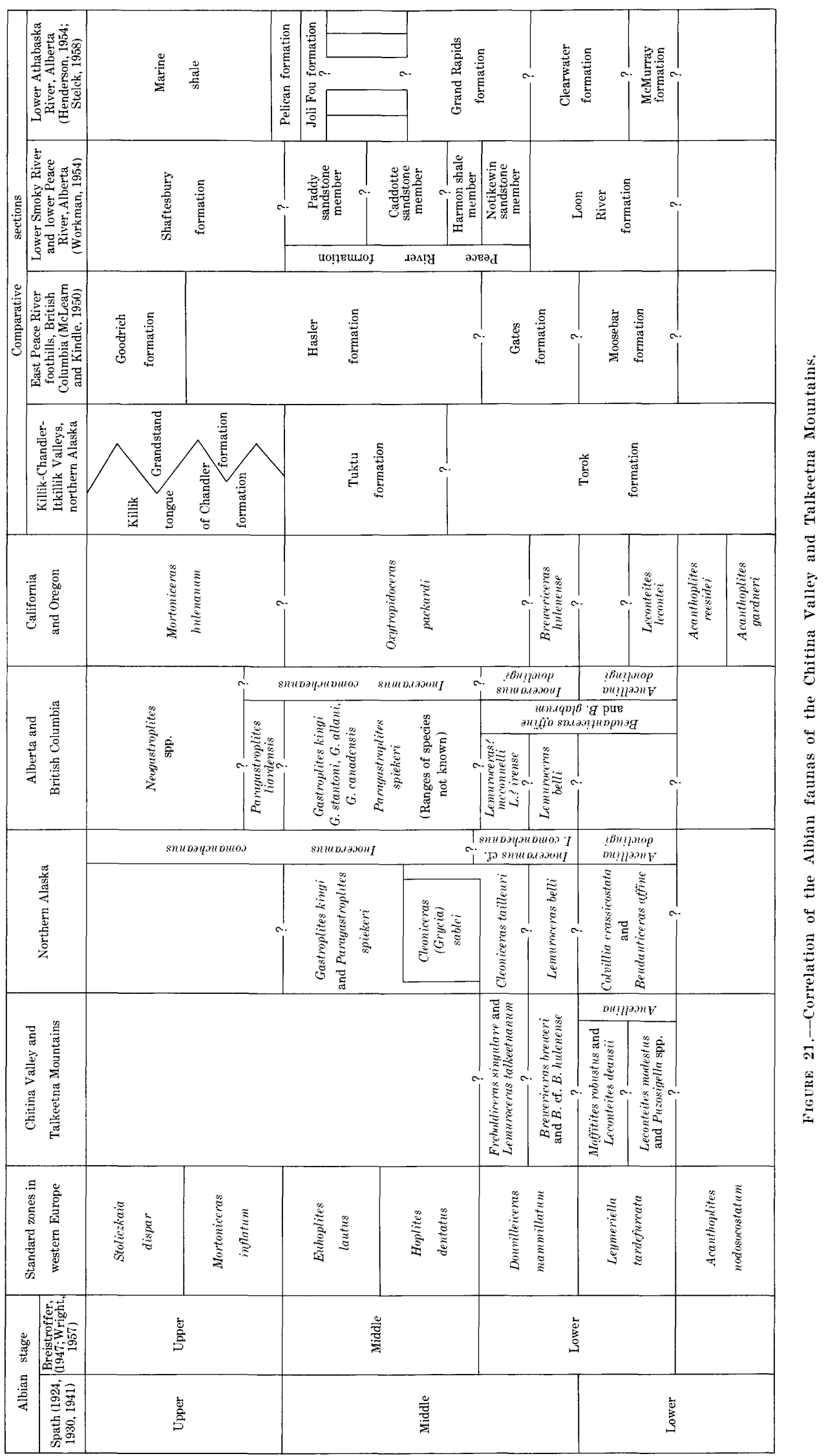




\section{MOFFITITES ROBUSTUS AND LECONTEITES DEANSI FAUNULE}

This faunule (fig. 21) is represented in the Chitina Valley at many localities along Bear and Fohlin Creeks (USGS Mes. loc. 2147, 2191, 2201, 8872, 8873, 8875, $8876,8878,8880,9966,9967,9967 \mathrm{a}, 9972,9973,9976$, $9978,14471,14484,14485)$, and at single localities along Fourth of July Creek (USGS Mes. loc. 14467), Trail Creek (USGS Mes. loc. 9950), and 3 miles west of the mouth of Canyon Creek (USGS Mes. loc. 9489). The most common ammonites are Moffitites robustus Imlay, Kennicottia bifurcata Imlay, Leconteites deansi (Whiteaves), L. crassicostatus Imlay, n. sp., and $A n$ gaudryceras aurarium. (Anderson). Somewhat less common are Phyllopachyceras cf. P. shastalense (Anderson), Calliphylloceras cf. C. aldersoni (Anderson), Ptychoceras cf. P. laeve (Gabb), Callizoniceras (Wo7lemanniceras) alaskanum. Imlay, n. sp., $C$. (W.) fohlinense Imlay, n. sp., Kennicottia rugosa Imlay, n. sp., Puzosia sp., and Leconteites aff. L. deansi (Whiteaves). These ammonites are associated with the pelecypod $A u$ cellina (pl. 19, figs. 28-32) which locally occurs in great numbers and has been obtained at many more localities than the ammonites.

The Moffitites robustus faunule is of early Albian age-only a little younger than the underlying faunule containing Leconteites modestus (Anderson) and Puzosigella. This is indicated by the close stratigraphic association of the faunules and by the presence in both of the genus Leconteites, which in California has been found only in the Leconteites lecontei zone of early Albian age. Similarly, the presence of Callizoniceras (Wollemanniceras) is excellent evidence that the Moffitites robustus faunule is not younger than early Albian (Wright, 1957, p. L363).

The Moffitites robustus faunule is not correlated with either the Leconteites lecontei zone or the overlying Brewericeras hulenense zone in California (Murphy, 1956, p. 2118) because the only species in common with those zones is Anagaudryceras aurarium. (Anderson) and because those zones may be correlated respectively with the Leconteites modestus faunule and the Brewericeras breweri faunule of the Chitina Valley. Both stratigraphically and faunally, therefore, the Moffitites robustus faunule appears to occupy a position intermediate between the California zones in question. Such a position is not in conflict with recent studies in California. Inspection of the zonal map prepared by Murphy (1956, fig. 5 on p. 2109) for the Cottonwood area near Ono, Calif., shows that there is ample space stratigraphically for another faunule zone between the Leconteites leciontei and Brewericeras hulenense zones.
BREWERICERAS BREWERI AND B. CF. B. HULENENSE FAUNULE

This faunule is represented in the upper part of the Chitina Valley at USGS Mesozoic localities 9480 and 9492 near the head of Young Creek, at USGS Mesozoic locality 14514 near the foot of Nizina Glacier, and probably at USGS Mesozoic locality 6313 near the head of McCarthy Creek. The fossils at localities 9492 and 6.313 were obtained from concretions in sandstone, but the characteristics of the beds at the other localities is not known. As all these localities are many miles from the localities that furnished Leconteites and Woffitites, the thickness of the stratigraphic unit involved is not known.

The fossils in the faunule characterized by Brewericeras breweri (Gabb) are listed by localities as follows:

Phyllopachyceras rhitinunum Imlay. n. s1-_-_-_-_-_-- 9492 Hypophylloceras of. H. californicum (Anderson) _.___ 9492

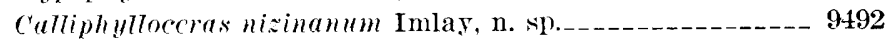
Anagaudryceras sp. indet_________________. 6313 Kossmatella cappsi Imlay, n. n1__._._..._._. 9492, 14514 Tetragonites aff. T. timotheamus (Pictet)__-___._._. 9492 Taldedorsclla? whitearesi Imlay, n. sl.._______._. 9492 Puzosia. alastiana Imlay, n. sl_________________ 9492 Breucriccras breupri (Gabb) _._..._._. 9492 (f. B. Hulencuse (Anderson) _._.____ 6313, 9492, 14514 Desmoceras sp. juv________ 9492

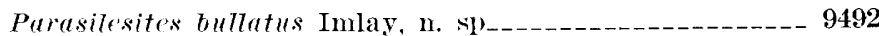
irreqularis Imlar, n. sp_____________- 9492 Hulenites rf. H. residei (Anderson) _-__-_-_-_-_ 9480, 9492 cleonicents oucrbecki Inrlay, n. sp__.___________ 9492 Lemuroceras (Nubrerthoplites) aff. L. belli MICLearn__-_ 9492

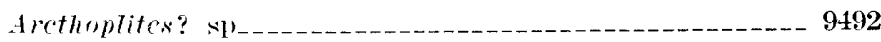

The only abundant ammonites among those listed are Puzosia alaxkana Imlay, n. sp., Calliphylloceras nizinanum Imlay, n. sp., Brevericeras breweri (Gabb), and $B$. cf. B. hulenense (Anderson). All other species are represented by five specimens or less. Associated with these ammonites are many other mollusks (Moffit, 1918, p. 40), of which the most significant stratigraphically are small specimens of Inoceramus that resemble immature specimens of $I$. comancheanus Cragin (equals I. anglicus Woods). Also, of stratigraphic significance is the absence of the pelecypod Aucellina. which is abundant in the older beds containing Leconteites and Moffitites.

The beds in the Chitina Valley that contain Brewericeras breweri (Gal)b) and B. cf. B. hulenense (Anderson) are considered to be approximately equivalent to the zone of B. hutenense in northern California (Murphy, 1956 , p. 2118, fig. 6) because they both contain the same coarsely ribbed variant of $B$. breweri (Gabb) that was illustrated by Whiteaves $(1876$, p. 21 , pl. 1 , figs. 2, 2a, 3, 3a) from the Queen Charlotte Islands. Also, the specimens herein compared to $B$. hutenense (Anderson) are probably inmature examples of that 
species rather than of $B$. haydeni (Gabb). Otherwise the Alaskan Brewericeras breweri faunule differs from the ammonites in the $B$. hulenense zone in California by the absence of the genus Douvilleiceras and the presence of the genera Taldedorsella, Parasilesites. Hulenites, Cleoniceras, and Lemuroceras (Subarcthoplites).

The Brewericeras hulenense zone in California may be correlated with the Douvilleiceras mammillatum zone in Europe on the basis of containing an abundance of Douvilleiceras and of being in the middle of the local range of Douvilleiceras. Similarly the underlying Leconteites lecontei zone may be correlated with the lowest occurrence of Douvilleiceras in Europe in the upper part of the Leymeriella tardefurcata zone. If these correlations are correct, the age of the $B$. hulenense zone should be late early Albian, according to the classification used by Wright (1957, p. L128) and Breistroffer (1947, p. 51, 53), or early middle Albian, according to the classification used by Spath (1941, p. 668).

Concerning the age of the beds in Alaska that contain Brewericeras breweri (Gabb), an early rather than middle Albian age is indicated by the presence of such genera as Taldedorsella and Lemuroceras (Subarcthoplites). Of these, Taldedorsella has not been found above the lower Albian in Europe; Parasilesites belongs in a family that is not known above the lower Albian; and the subgenus Subarcthoplites occurs in northern Alaska about 600 feet below the lowest known occurrence of Cleoniceras, which ranges through more than 2,500 feet of strata (Imlay, 1960).

\section{FREBOLDICERAS SINGULARE FAUNULE}

This faunule is represented in the Talkeetna Mountains by the ammonites Tetragonites sp., Freboldiceras singulare Imlay, Beudanticeras glabrum (Whiteaves), $B$. (Grantziceras) multiconstrictum. Imlay; and Lemuroceras talkeetnanum Imlay, n. sp. The faunule is of unusual interest because of the excellent preservation of the specimens, because its component species show close affinities with Albian species in the western interior of Canada and in India, and because its genera and species have no known affinities with the Albian ammonites of California or Oregon, although they occur in the same marine basin as the Albian ammonites of the Chitina Valley that are closely related to ammonites in California and Oregon.

The age of the ammonite faunule in question from the Talkeetna Mountains is either early Albian or early middle Albian on the basis of comparisons with similar ammonites in the western interior of Canada. The presence of Beudanticeras glabrum. (Whiteaves) indicates a correlation with Albian beds in Canada below the lowest occurrence of the ammonite Gastroplites in the Harmon shale member of the Peace River formation (Henderson, 1954, p. 2285, 2286; Stelck and others, 1956 , p. 10,12$)$. The resemblance of Freboldiceras singulare Imlay to "Lemuroceras" irenense McLearn (1945, pl. 5, fig. 5; 1948, p. 2) from the upper part of the Moosebar formation of British Columbia (Stelck and others, 1956, p. 10) suggests an age slightly younger than that of Lemuroceras (Subarcthoplites) belli McLearn (1945, pl. 3, figs. 17, 18; 1948, p. 2) from the Clearwater formation and the upper part of the Loon River formation (McLearn and Kindle, 1950, p. 86, 93). However, the resemblance of Lemuroceras talkeetnanum Imlay, n. sp., to Lemuroceras cf. L. indicum Spath (McLearn, 1945, pl. 5, fig. 4) from the lower part of the Loon River formation (Stelck and others, 1956 , p. $6,11,14$ ) suggests an age slightly older than that of Lemuroceras belli McLearn.

The fact that Lemuroceras talkeetnanum Imlay, $\mathrm{n}$. sp., is remarkably similar to L. indicum (Spath) (1933, p. 801, pl. 129, fig. 5) from India and Madagascar (Collingnon, 1949, p. 68, 69, pl. 12, figs. 2, 2a, b, pl. 14, fig. 2) suggests that it is of nearly the same age as that species and that the Freboldiceras singulare faunule may be correlated with the Old World Douvilleiceras mammillatum zone. As just discussed, however, correlation with that zone seems reasonable, also, for the Brevericeras hulenense zone in California and for the $B$. breweri faunule in the Chitina Valley which have an entirely different ammonite assemblage than the faunule in the Talkeetna Mountains. This difference is especially significant for correlation purposes considering that the Albian beds of the Talkeetna Mountains and of the Chitina Valley were deposited in the same basin and, therefore, that the ammonites in those beds should not differ greatly provided they are of the same age.

Therefore, the Albian fossils from the Talkeetna Mountains are either slightly younger or slightly older than the Brewericeras breweri faunule in the Chitina Valley. The matter cannot be settled definitely on the basis of available evidence, but a younger age is suggested by the fact that in northern Alaska the beds containing Lemuroceras belli McLearn are underlain by beds containing Albian ammonites that are considerably different than those in the Talkeetna Mountains. Accordingly the Freboldiceras singulare faunule is probably younger than the Lemuroceras belli zone of Canada and northern Alaska and should be sought in the upper part of the Moosebar formation and in the Gates formation of British Columbia and in the Notikewin member of the Peace River formation of Alberta. Such a correlation would agree with the general 
resemblance of Freboldiceras singulare Imlay to "Lemuroceras" irenense McLearn.

\section{OTHER ALBIAN FAUNULES}

Some fossil collections of late Albian to Cencmanian ages have been obtained from the valley of the Nizina Glacier (USGS Mes. locs. 14038, 14040, 14511, 14515) and about 30 miles south-southeast of that glacier in an area northwest of Gibraltar Hill (USGS Mes. locs. 9481, 9485-9487). Most of the fossils were corsidered to be of Albian age by Imlay and Reeside (195t, p. 230 ), but recent studies by Matsumoto (1959, p. 85, 86) show that USGS Mesozoic locality 9481 contains fossils of probable Cenomanian age and that the other localities contain long-ranging species that could be of late Albian or of Cenomanian age. A definite age determination must await additional collecting. Considering these age limitations, it is interesting that plant fossils obtained from USGS Mesozoic localities 9481 and 9486 and from many localities of early to middle Albian age in the Chitina Valley have been identified by F. H. Krowlton as definitely Late Jurassic (Moffit and Overbeck, 1918, p. 42, 44; Martin, 1926, p. 336-346; Moffit, 1938, p. 88).

\section{COMPARISONS WITH OTHER FAUNAS}

The Albian ammonites from the Chitina Valley belong in the same faunal province as the Albian ammonites of California and Oregon as shown by the presence of the genera Brewericeras, Hulenites, Puzosigella, and Leconteites. However, some kind of faunal connection with the western interior of Canada and with northern Alaska is shown by the presence of Lemuroceras (Subarcthoplites) in association with Brewericeras. Also the presence of Callizoniceras, knowm elsewhere only from Greenland and northwest Europe, suggests some kind of connection through Canada or northern Alaska with the boreal province. The genera Moffitites and Kennicottia have not yet been reported from California or Oregon but are present in U.S. Geological Survey collections from the Queen Charlotte Islands and may be expected farther south. Most of the other genera are widely distributed in many parts of the world.

The few Albian ammonites from the Talkeetna Mountains in contrast with those from the Chitina Valley belong in the same faunal province as the Albian ammonites of the western interior of Canada and of northern Alaska and have not yet been found in California and Oregon. This is shown by the presence of Beudanticeras glabrum (Whiteaves), which is common in the western interior of Canada, and of species of Beudanticeras, Freboldiceras, and Lemuroceras that are closely similar to Canadian species. Such a relationship is surprising because any Albian beds in or near the Talkeetna Mountains must have been deposited in the same marine sedimentary basin as the Albian beds of the Chitina Valley. These facts mean either that there was some mixing of the Albian faunas of the interior region, which are of boreal origin, with those of the Pacific coast during Albian time or that the faumas were actually not distinct. In this connection the presence of a species of Lemuroceras in the Talkeetna Mountains similar to L. indicum (Spath) from India and Madagascar (Spath, 1933, pl. 128, figs. ta, b, 5a, b; Collignon, 1949, pl. 12, figs. 2, 2a, b, pl. 1t, figs. 2) and to a species from the western interior of Canada (McLearn, 1945, pl. 5, fig. 4) suggests that the Albian ammonite faunules of the western interior of Canada and of northern Alaska may have had a much wider distribution than now realized.

In summation, the Albian ammonite assemblage in southern Alaska is predominantly related to the Albian ammonite assemblage in California and Oregon, but includes some genera and species that are boreal in origin, and others that occur in Albian beds in many parts of the world.

\section{GEOGRAPHIC DISTRIBUTION}

The occurrence by area and locality of the 45 species described in this report is indicated in table 3. The position of the two known areas of lower to middle Albian rocks in the southeastern part of the main body of Alaska is shown in figure 22, and the general position of each locality is shown in figures 23 and 24 . The positions of such localities as $2147,2173,2191$, 2201 , and 6313 may be in error by a mile or more because of inadequate field descriptions. Descriptions of the individual localities are given in table 2. This list does not include any localities mentioned in the text under such ages as Late Jurrassic, Early Cretaceous (Valanginian), or late Albian to Cenomanian. The description of such localities may be found in U.S. Geological Survey Bulletin 894 on pages 83-88.

\section{SUMMARY OF RESULTS}

The Early Cretaceous (Albian) ammonites from the Talkeetna Mountains and the upper part of the Chitina Valley discussed herein are well preserved and highly raried. They include 24 genera and 45 species. Of these species 18 are described as new. Of the 24 genera, 4 were described as new in a preliminary paper (Imlay, 1959) published during the course of this study.

Among the Albian ammonites the family Desmoceratidae is dominant in numbers, genera, and species. It is characterized by the genera Moffitites, Freboldiceras, 


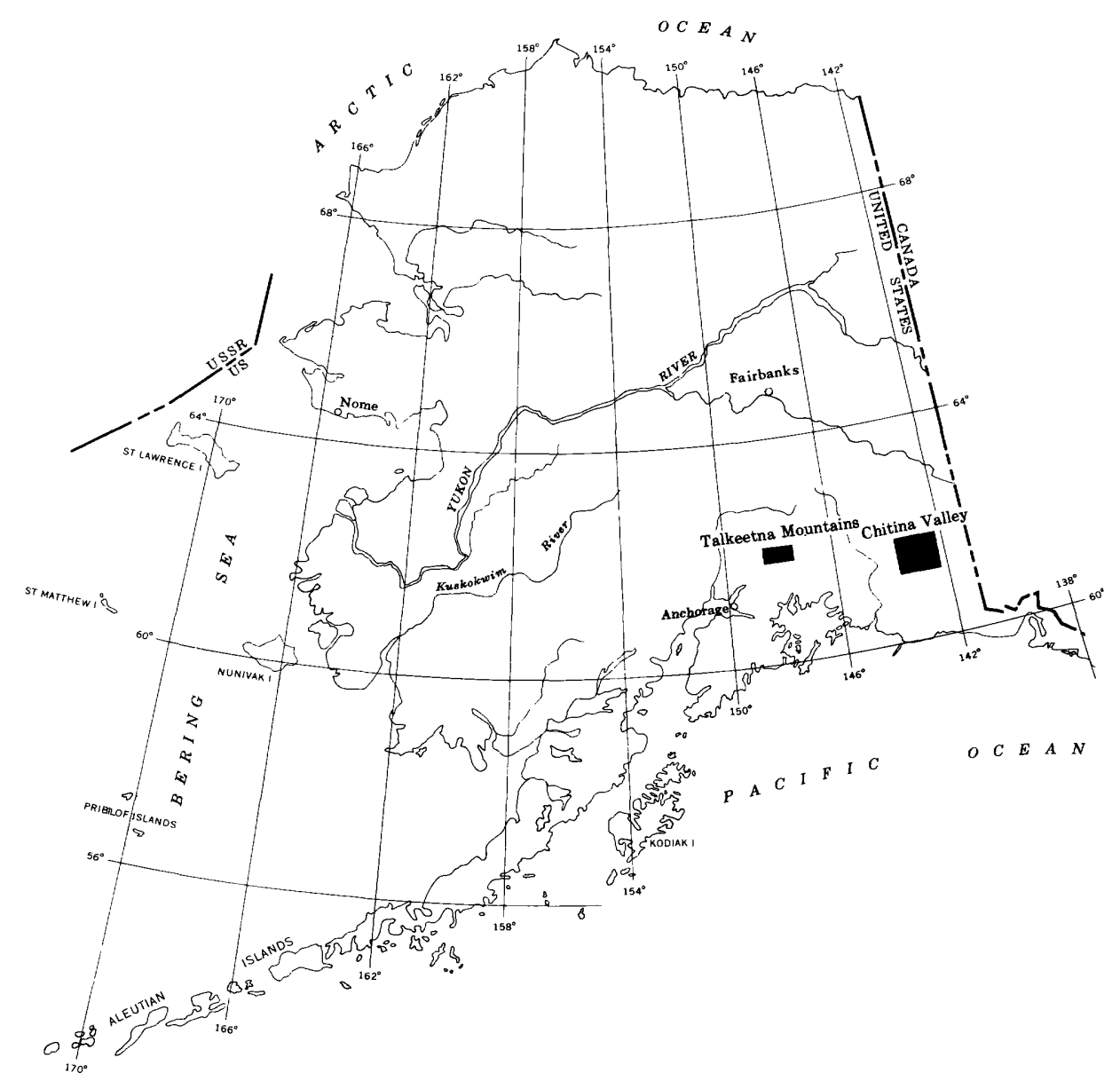

FIgUre 22.-Index map of the main areas of Albian fossils in the southeastern part of the main body of Alaska.

Kennicottia, and Brewericeras, which have not been recorded outside of the Pacific const of North America. It includes, also, the Old World genera Callizonicerces, Puzosia, Beudanticeras, and probably Traldedorsella and Desmoceras. Next in importance among the Albian ammonites is the family Hoplitidae. It is characterized by the genera Leconteites and Puzosigella, which have been found to date only on the Pacific coast of North America, but includes the widely distributed genera Cleoniceras and Lemuroceras. Of considerable lesser importance are the Phylloceratidae and Tetragonitidae. 'The Ptychoceratidae, Silesitidae, and Kossmaticeratidae are represented by only a few specimens.

The Albian beds include four ammonite famules. In the Chitina Valley the faunules, from oldest to youngest, are characterized by 1 , Leconteites modestus (Anderson) and Puzosigella spp.; 2, Moffitites robustus Imlay and Leconteites deansi (Whiteaves); 3, Brewericeras breweri (Gabb) and B. cf. B. hulenense (Anderson). In the Talkeetna Mountains occurs a fourth faunule characterized by Freboldiceras singulare Imlay. This faunule is probably younger than the other faunules, but the evidence is not conclusive.
The two lower faunules are associated with the pelecypod Aucellina.

The faunule characterized by Leconteites modestus and Puzosigella spp. is correlated with the Leconteites lecontei zone in California and Oregon and is of early Albian age.

The faunule characterized by Moffitites robustus Imlay and Leconteites deansi (Whiteaves) is considered to be intermediate in age between the Leconteites lecontei zone and the Brewericerts hulenense zone in California. An age not younger than earlier Albian is indicated by the presence of the genus Callizoniceras.

The faunule characterized by Brewericeras breweri (Gabb) and B. cf. B. hulenense (Anderson) is approximately equivalent to the Brewericeras hulenense zone in California because it contains the coarsely ribbed variant of Brewericeras breweri (Gabb) identical with that in the $B$. hulenense zone. The faunule in the Chitina Valley differs in other respects, however, and may not be an exact equivalent. Its age, judging by the presence of the ammonites Valdedorsella?, Parasilesites, and Lemuroceras (Subarcthoplites) is not younger than early Albian. 
CRETACEOUS AMMONITES FROM ChITIN VALLEY AND TALKEETNA MOUNTAINS

95

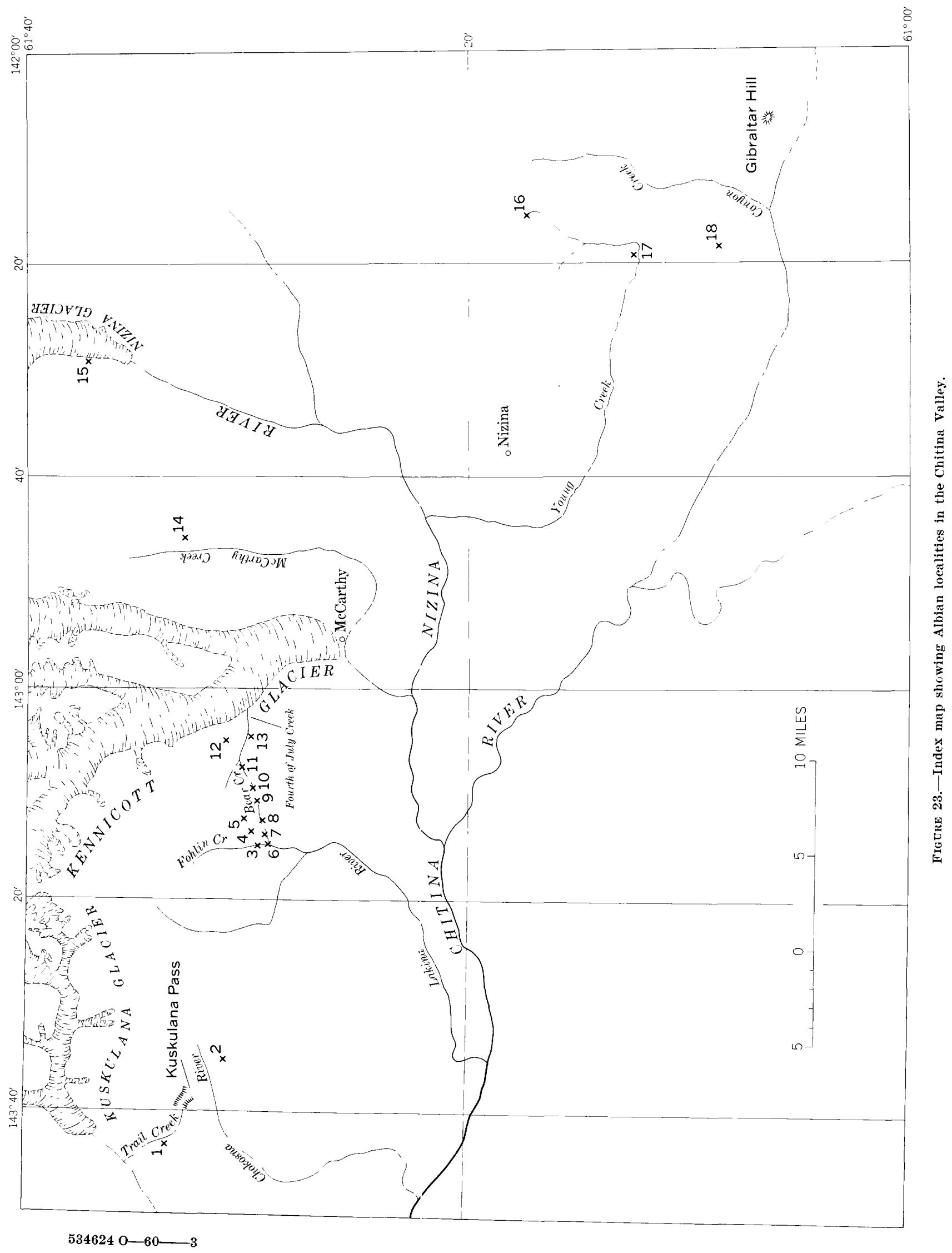


TABLE 2.-Localities at which ammonites were collected from the Albian strata of the Chitina Valley and the Talkeetna Mountains

\begin{tabular}{|c|c|c|c|}
\hline $\begin{array}{l}\text { Locality on } \\
\text { figs. } 2 \text { and } 3\end{array}$ & $\begin{array}{l}\text { Geological Sur- } \\
\text { vey Mesozoic } \\
\text { localities }\end{array}$ & $\begin{array}{l}\text { Collectors' field } \\
\text { Nos. }\end{array}$ & Collector, year of collections, description of locality, and lithologic features \\
\hline & 9950 & & Moffit, F. H., 1916. On west side of Trail Creek at altitude of $3,500 \mathrm{ft}$, Chitina Valley. \\
\hline & & & $\begin{array}{l}\text { Moffit, F. H., 1928. Near head of Chokosna River, } 1 \text { mile up southern tributary that joins } \\
\text { river at the Kuskulana Trail, Chitina Valley. }\end{array}$ \\
\hline 3... & 8873 & 57 & Martin, G. C., and Overbeck, R. M., 1914. East bank of Fohlin Creek, 4,900 ft north of \\
\hline 3. & 8875 & 60 & Martin, G. C., and Overbeck, R. M., 1914. East bank of Fohlin Creek about 6,800 ft \\
\hline 3.. & 8876 & 61 & Martin, G. C., and Overbeck, R. M., 1914. East bank of Fohlin Creek 5,500 ft north of \\
\hline & 14484 & $28 \mathrm{AM}-\mathrm{F} 21$ & Moffit, F. H, 1928. Fohlin Creek 1 mile north of Bear Creek. Near Mes. loc. 8873, \\
\hline & 14485 & $28 \mathrm{AM}-\mathrm{F} 22$ & $\begin{array}{l}\text { Chitina Valley. } \\
\text { Moffit, F. H., 1928. Fohlin Creek } 100 \mathrm{yds} \text { north of Mes. loc. 14484, Chitina Valley. }\end{array}$ \\
\hline & & 54 & $\begin{array}{l}\text { Moffit, F. H., 1916. At falls on first northern tributary of Bear Creek at altitude of } 3,200 \\
\text { ft and a little more than } 1 \text { mile from Bear Creek, Chitina Valley. }\end{array}$ \\
\hline & 14487 & $28 \mathrm{AM}-\mathrm{F} 24$ & Moffit, F. H., 1928. First northern tributary of Bear Creek, 1 mile above its mouth, Chitina \\
\hline 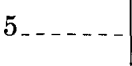 & 14471 & AM-F8 & Moffit, $\dot{\mathbf{F}}$. H., 1928. About $1 \frac{1 / 2}{2}$ miles north of Bear Creek and the same distance east of \\
\hline & 9976 & 59 & $\begin{array}{l}\text { Fohlin Creek, Chitina alley. } \\
\text { Moffit, F. H., 19l6. On Fohlin Creek } 125 \mathrm{ft} \text { above mouth of Bear Creek, Chitina Valley. }\end{array}$ \\
\hline & & 61 & $\begin{array}{l}\text { Moffit, F. H., } 1916 \text {. On Fohlin Creek, } 1,300 \mathrm{ft} \text { upstream from Mes. loc. 9976, Chitina } \\
\text { Valley. }\end{array}$ \\
\hline & 2147 & 3 & Rohn, Oscar, 1899. Creek between Lakina River and Fohlin Creek between camps 11 and \\
\hline & 2191 & 1048 & Schrader, F. C., and Spencer, A. C., 1900. Creek tributary to the Lakina River half a mile \\
\hline & 2201 & 5 & Schrader, F. C., and Spencer, A. C., 1900 . Old trail between Lakina and Kennicott Rivers, \\
\hline & 9966 & & Moffit, F. H., 1916. Half a mile above mouth of Bear Creek on first tributary from north, \\
\hline & 9967 & 50 & n from Mes. loc. 9966, Chitina Valley. \\
\hline & & 50 & Moffit, F. H., 1916. Float from Mes. loc. 9967, Chitina Valley. \\
\hline & 2173 & 6 & Rohn, Oscar, 1899. Small canyon between camp 13 and the Kennicott Glacier, Chitina \\
\hline & 9972 & 55 & $\begin{array}{l}\text { Moffit, F. H., 1916. On Bear Creek at altitude of } 2,850 \mathrm{ft} \text { about half way from Fohlin } \\
\text { Creek to Fourth of July Pass. Soft, gray sandstone containing nodular masses, Chitina } \\
\text { Valley }\end{array}$ \\
\hline & 9973 & 55 & $\begin{array}{l}\text { Valley. } \\
\text { Moffit, F. H., 1916. On Bear Creek near Mes. loc. 9972, Chitina Valley. }\end{array}$ \\
\hline & 8872 & 5 & $\begin{array}{l}\text { Martin, G. C., and Overbeck, R. M., 1914. Float in Bear Creek about } 2 \frac{1}{2} \text { miles above its } \\
\text { mouth, Chitina Valley. }\end{array}$ \\
\hline & 8877 & 62 & $\begin{array}{l}\text { Martin, G. C., and Overbeck, R. M., 1914. Bear Creek about } 3 \text { miles above mouth, Chitina } \\
\text { Vallev. }\end{array}$ \\
\hline & 8878 & 63 & $\begin{array}{l}\text { Martin, G. C., and Overbeck, R. M., 1914. } 100 \mathrm{yds} \text { above Mes. loc. } 8877 \text { on Bear Creek, } \\
\text { Chitina Valley. }\end{array}$ \\
\hline & 8880 & 65 & Martin, G. C., and Overbeck, R. M., 1914. Bear Creek about $400 \mathrm{ft}$ below summit of Fourth \\
\hline 12 & 14466 & $28 \mathrm{AM}-\mathrm{F} 4$ & $\begin{array}{l}\text { Moffit, F. H., 1928. Northern tributary of Fourth of July Creek } 1 \frac{1}{2} \text { miles from its mouth, } \\
\text { Chitina Vallev. }\end{array}$ \\
\hline & 14467 & $28 \mathrm{AM}-\mathrm{F} 4 \mathrm{a}$ & Moffit, F. H., 1928. Same as Mes. loc. 14466. \\
\hline & & & Moffit, F. H., 1928. Near Mes. loc. 14466, Chitina Valley. \\
\hline & 11389 & 10 & Moffit, F. H., 1922. On Fourth of July Creek 2 miles from Kennicott Glacier, Chitina \\
\hline & 6313 & & Moffit, F. H., 1909. MeCarthy Creek. Base of Kennicott formation. \\
\hline & & & Moffit, F. H., 1928. West side of Nizina Glacier 1 mile from its lower end. Chitina Valley. \\
\hline & & & Moffit, F. H., and Overbeck, R. M., 1915. Float from upper part of east branch of Young \\
\hline & 9492 & 34 & $\begin{array}{l}\text { Moffit, F. H., and Overbeck, R. M., 1915. From concretions in sandstone in bluffs on } \\
\text { north side of Young Creek west of big bend at altitude of } 3,450 \mathrm{ft} \text { and half a mile above } \\
\text { foot of trail to the Chitina River, Chitina Valley. }\end{array}$ \\
\hline 8 & 9489 & 31 & Moffit, F. H., and Overbeck, R. M., 1915. From nodules in sandstone near \\
\hline & 24877 & $53 \mathrm{AGz} 137$ & $\begin{array}{l}\text { Grantz, A. and Fay, L. F., } 1953 \text {. Concretions in basal siltstone of the Matanuska formation } \\
\text { overlying the Nelchina limestone near head of Billy Creek, Talkeetna Mts. (A-2) quad., }\end{array}$ \\
\hline & 25320 & $54 \mathrm{AGz} 53$ & $\begin{array}{l}\text { lat } 62^{\circ} 01^{\prime} 401^{\prime \prime \prime} \mathrm{N}^{\prime \prime} \mathrm{N} \text {, long } 147^{\circ} 39^{\prime} 18^{\prime \prime} \mathrm{W} \text {., Talkeetna Mts. } \\
\text { Grantz, A., } 1954 \text {. Concretions in basal siltstone of the Matanuska formation overlying } \\
\text { the Nelchina limestone near the head of Flume Creek. Talkeetna Mts. (A-2) quad. } \\
\text { lat } 62^{\circ} 00^{\prime} 41^{\prime \prime} \mathrm{N} \text {. long } 147^{\circ} 34^{\prime} 46^{\prime \prime} \text { W. Talkeetna Mts. The }\end{array}$ \\
\hline $20 \ldots$ & 25329 & 54AGz56L & $\begin{array}{l}\text { Grantz, A., } 1954 \text {. Concretions in basal siltstone of the Matanuska formation overlying } \\
\text { the Nelchina limestone near the head of Flume Creek. Talkeetna Mts. (A-2) quad., } \\
\text { lat } 62^{\circ} 00^{\prime} 41^{\prime \prime} \text { N., to lat } 62^{\circ} 00^{\prime} 43^{\prime \prime} \text { N., long } 147^{\circ} 34^{\prime} 46^{\prime \prime} \text { W., to long } 147^{\circ} 34^{\prime} 54^{\prime \prime} \text { W., } \\
\text { Talkeetna Mts. }\end{array}$ \\
\hline
\end{tabular}




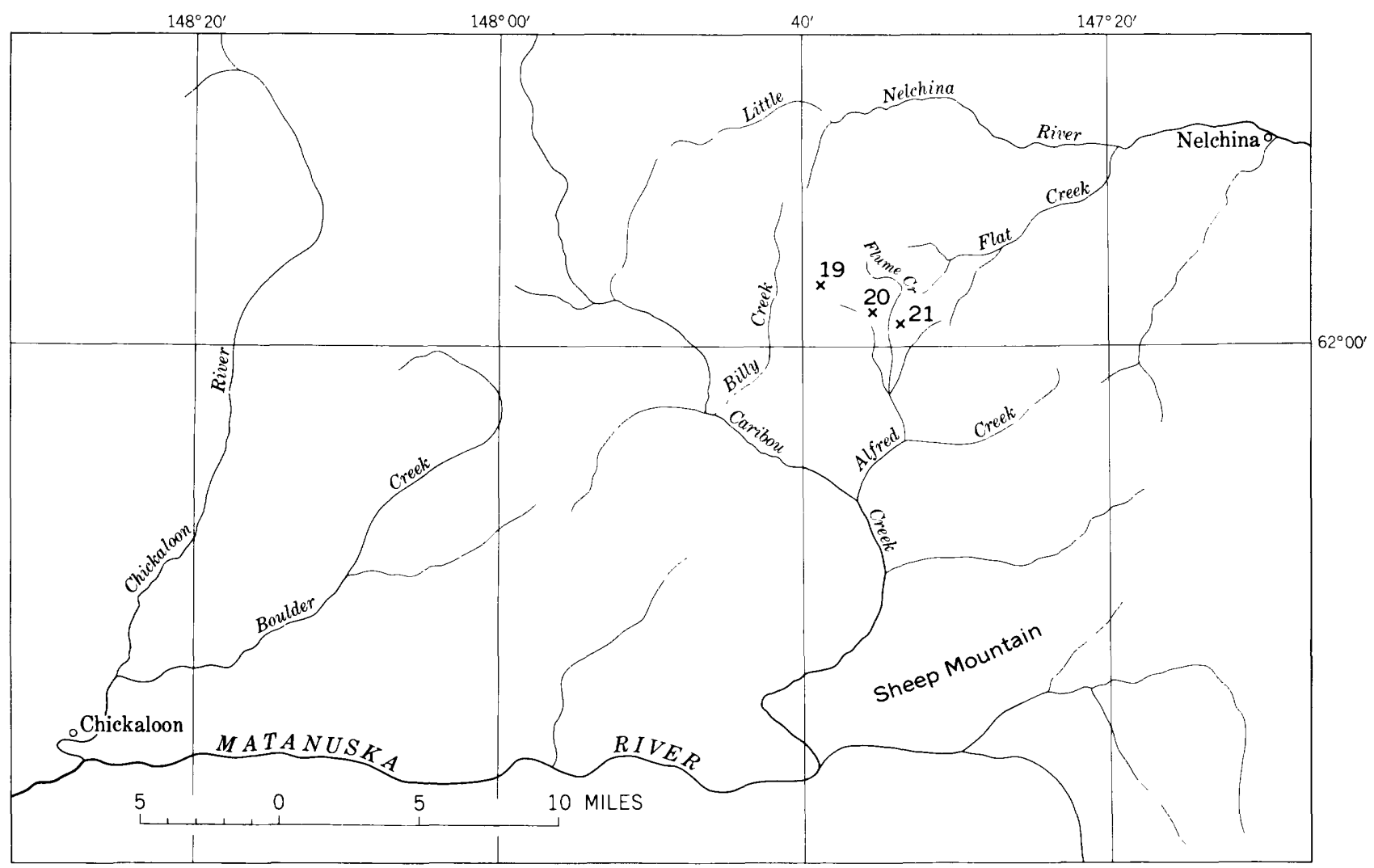

Figure 24.--Index map showing Albian localities in the Talkeetna Mountains.

The faunule characterized by Freboldiceras singulare Imlay contains Albian ammonites that are unlike those in the Chitina Valley or in California, but are identical with or closely similar to species in the western interior of Canada. The faumule is correlated with beds in Canada that overlie the zone of Lemuroceras belli and underlie the zone of Gastroplites kingi, but the evidence is not conclusive. If this correlation is correct, it is probably younger than the Brewericeras breweri faunule in the Chitina Valley on the basis that that faunule contains a species of Lemuroceras that occurs in the zone of Lemuroceras belli in northern Alaska.

Other ammonite faunules of late Albian age are possibly represented in the Chitina Valley at certain localities near the base of Nizina Glacier and near the mouth of Canyon Creek. The collections on hand, however, contain only long-ranging species that could be of Cenomanian age.

The Albian ammonites from the Chitina Valley belong to the same faunal province as the Albian ammonites of California and Oregon as shown by the presence of the genera Brewericerus. Hulenites, Puzosigella, and Leconteites. A possible connection with the boreal province is indicated, however, by the pres- ence of Lemurocerts (Subarcthoplites) and Callizonireras. In contrast the Albian ammonites from the Talkeetna Mountains belong to the same faunal province as those in the western interior of Canada and in northern Alaska. It appears, therefore, that the Albian sea that covered the areas now occupied by the Chitina Valley and Talkeetna Mountains had broad connections with the seas in the western interior of the continent and in California. Careful stratigraphic collecting from the Albian beds in the Chitina Valley would probably furnish the eridence for precise interregional correlations.

\section{SYSTEMATIC DESCRIPTIONS}

\section{Class CEPHALOPODA Genus PHYLIOPACHYCERAS Spath, 1925 \\ Phyllopachyceras chitinanum Imlay, n. sp.}

Plate 11, figures 1-5

This species is represented only by the holotype. Whorls orate in section, a little higher than wide, widest near middle of flanks, becoming stouter during growth. Flanks gently convex, rounding evenly into umbilical wall and into arched venter. Umbilicus extremely narrow. Body chamber occupies three-fifths of a whorl and appears to be nearly complete. 
TABLE 3.-Geographic distribution of early Albian ammonites from the Chitina Valley and Talkeetna Mountains, Alaska [Numbers 1-21 refer to numbers on figs. 23 and 24. Higher numbers are Geological Survey Mesozoic locality numbers]

\begin{tabular}{|c|c|c|c|c|c|c|c|c|c|c|c|c|c|c|c|c|c|c|c|c|c|c|}
\hline & \multicolumn{20}{|c|}{ Chitina Valley } & & \\
\hline & \multicolumn{18}{|c|}{ Kennicott formation } & $\begin{array}{l}\text { Undivided } \\
\text { Lower } \\
\text { Cretaceous }\end{array}$ & & & \\
\hline & \begin{tabular}{|l|l}
1 & 2 \\
2 & $l$
\end{tabular} & & 3 & & 4 & 5 & & 6 & & 7 & & 8 & & & & 11 & 12 & & \begin{tabular}{ll|l|l|l|l|l} 
& 14 & 15 & 16 & 17 & i
\end{tabular} & \begin{tabular}{l|l}
18 & 19
\end{tabular} & 20 & 21 \\
\hline & 象 & 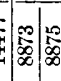 & & 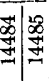 & & & & & 突| & & : & & & & & & 象象 & 跣 & & & 吉 & 蛹 \\
\hline hyllopachyceras & & & & & & & & & & & & & & & & & & & & & & \\
\hline 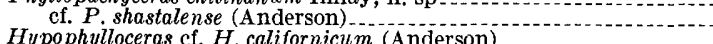 & & & & & & & & & & & & $\ddot{x}$ & & &.-- & & & & & & & $-\cdots$ \\
\hline $\begin{array}{l}\text { Hypophylloceras cf. H. californicum (Ant } \\
\text { Calliphylloceras nizinanum Imlay, n. sp. }\end{array}$ & & & $-\infty$ & & & & & - & & $-\infty$ & -- & 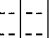 & -- & & -- & & 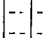 & 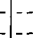 & 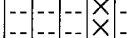 & $-\cdots$ & $\cdots$ & 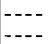 \\
\hline $\begin{array}{l}\text { c. C. C. aldersoni (Anderson) } \\
\text { Ano }\end{array}$ & & & & & & & & & & & & $\bar{x}$ & & & $-=$ & & & & & & $\cdots$ & \\
\hline $\begin{array}{l}\text { Anaguary } \\
\text { of. A. aurarium (Anderson) }\end{array}$ & & & & & & & & & & & & & & & -- & & & & 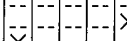 & & .... & 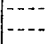 \\
\hline Kossmatella cappsi Imlay, n. & & & & & & & & & & & & -7 & & & -- & & & & $|x|-|-| x \mid-2$ & & $\cdots$ & $\cdots$ \\
\hline 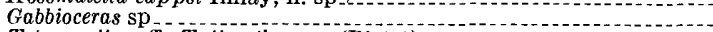 & & & & & & & & & & & & & & & $\begin{array}{l}-- \\
-\end{array}$ & & & & 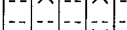 & & 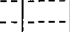 & --.- \\
\hline afi. T. timotheanus (Pictet & & & & & & & & & & & & & & & {$[--1$} & & & & $-\cdots \times$ & & $\cdots$ & \\
\hline $\begin{array}{l}\text { sp. indet } \\
\text { Ptuct }\end{array}$ & $--1-$ & & & & & & & & & & & - & & & - & & & $\begin{array}{l}-- \\
-\end{array}$ & 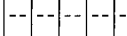 & $-x$ & $\times$ & $-\cdots$ \\
\hline & $\ldots-1$ & & & & & & & & - & & - & - & & & $\mid \begin{array}{lll}- \\
--\end{array}$ & & {$\left[\begin{array}{c}- \\
--\end{array}\right.$} & $-\infty$ & $\left|\begin{array}{c}- \\
-\end{array}\right| \bar{x} \mid-1$ & & {$[--$} & $\cdots$ \\
\hline Callizon & & $x$ & & & & & & & & & -- & --... & & & $=1$ & -- & -- & $\because$ & 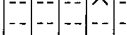 & & -..- & $\cdots$ \\
\hline $\begin{array}{l}\text { (W.) fohlinense Imlay, n. sp.... } \\
\text { Moffitites robustus Imlay. }\end{array}$ & & & & & & & & & & & $-\bar{x}$ & & & & $\ddot{x}$ & & $--\mid-$ & & & & $\cdots$ & -- \\
\hline $\begin{array}{l}\text { Moffiteses robustus Imlay } \\
\text { of. } M \text {. robustus Imlay, n. sp. }\end{array}$ & 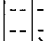 & & - & & & & & & & & & $\bar{x} \bar{x}$ & & & 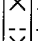 & & $\bar{x}-$ & -- & 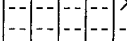 & & (n) & $-\cdots$ \\
\hline $\begin{array}{l}\text { crassi } \\
\text { crastice }\end{array}$ & 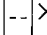 & $x \mid--$ & $-\ldots$ & ---- & & & & -- & & & $\ldots$ &.--- & & & $x \mid$ & & $--\mid-$ & $-\infty$ & $|-|--\mid---$ & & --- & --- \\
\hline $\begin{array}{l}\text { Freboldicer } \\
\text { Kemnicotti }\end{array}$ & & 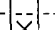 & & & & & & $\ldots$ & & & & $-\bar{x}$ & & & -- & & --- & - & $|---|---$ & & --- & $\cdots$ \\
\hline $\begin{array}{l}\text { Kennicottia bifu } \\
\text { rugosa Imla }\end{array}$ & & 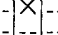 & $-\cdots$ & 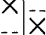 & & & & & & & & $-x$ & & & $-=$ & & - & $-\infty$ & 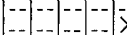 & & $\cdots$ & $\cdots-$ \\
\hline Puzosia alaskan & & & & & & & & & & & & & & & 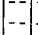 & & & & 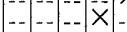 & & -..- & \\
\hline & & & & & & & & & & & & & & & & & & & & & .... & \\
\hline $\begin{array}{c}B e u d a \\
(G\end{array}$ & & & & & & & & & & & & & & & -- & & & & $\ldots-\ldots$ & & $-\overline{-}$ & $-\overline{-}$ \\
\hline $\begin{array}{l}\text { (Grantziceras) mulliconstrict } \\
\text { Breprericerso breperi (Gabh) }\end{array}$ & & & & & & & & & & & & & & & -- & & & & $---|-|-\mid-$ & & $\times$ & $x$ \\
\hline $\begin{array}{l}\text { Brewericeras breweri (Gabb) } \\
\text { cf. B, hulenense (Anderson) }\end{array}$ & & & & & & & & & & & & & & & {$\left[\begin{array}{ccc}- \\
--\end{array}\right.$} & & & & 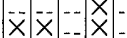 & & $\cdots$ & $\cdots$ \\
\hline Desm & & & & & & & & & & & & & & & $\mid$ & & & & $\left.|\hat{-}| \hat{-}|--| \hat{x}\right|^{-}$ & & & \\
\hline Para. & & & & & & & & & & & & & & & & & & & 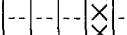 & & & $-\cdots$ \\
\hline $\begin{array}{rll}\text { irre } \\
\text { Hulenti }\end{array}$ & & & & & & & & & & & & & & & $--\mid$ & & & & 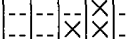 & & $\cdots$ & $\cdots-$ \\
\hline & & & & & & & & & & & & & & & 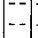 & & & & $\left.|--\cdots| \hat{x}\right|_{-} ^{-} \quad$ & & -..- & $\cdots$ \\
\hline Puzosigella cf. P. roger & & & & & & & & & & & - & & & & - & & -- & & $-\cdots$ & & $\cdots$ & $-\cdots$ \\
\hline & & & & & & & & & & & & & & & {$\left[\begin{array}{ll}- \\
--\end{array}\right.$} & & & & 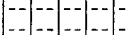 & & $\cdots$ & $\cdots-$ \\
\hline 8 modestus (Anderson) & & & & & & & & & & 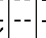 & & $-\bar{x}$ & & & -- & & & & ------ & & --- & $-\cdots$ \\
\hline inst (Wniteaves) & & & & & & & & & -. & $-\infty$ & &.- & & & & & & & $\mid \begin{array}{lll}- & - \\
- & - & - \\
- & -\end{array}$ & & $\cdots$ & $\cdots$ \\
\hline & & $-\bar{x}$ & & & & & & & & 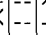 & & $-\bar{x}$ & & & $\bar{x}$ & & & & 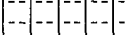 & & - & \\
\hline 2anum Imlay, n. sp s... & - & & $\ldots$ & & & & & & 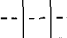 & -- & & & & & -- & & & & 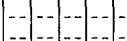 & $-x$ & $x \mid-\ldots$ & $-\cdots$ \\
\hline $\begin{array}{l}\text { sp juv. cf. } L \text { dubium Collignon } \\
\text { (Subarcthoplites) aff, } L \text {, belli McLearn- }\end{array}$ & - & & & & & & & & -- & 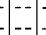 & & & & & & & $\ldots$ & & $\mid \begin{array}{lll}- & -1 & - \\
- & -1 & -1\end{array}$ & & $\cdots$ & $\cdots$ \\
\hline 1rcthoplites? sp & & & & & & & & & & & & & & & & & & & - & & & \\
\hline
\end{tabular}

The ornamentation on the adapical part of the body whorl consists of nearly microscopic raised lines. These are replaced adorally at a diameter of about 31 $\mathrm{mm}$ by low rounded ribs on the venter. Toward the aperture the ribs become stronger and originate at various heights on the middle and upper parts of the flanks. All ribs are of equal strength on the venter which they cross nearly transversely. The suture line has the tetraphyllic first and second lateral saddles that are typical in the genus.

The holotype has a maximum diameter of $38 \mathrm{~mm}$. At a diameter of $35 \mathrm{~mm}$, it has a whorl height of $22 \mathrm{~mm}$ and a whorl thickness of $21 \mathrm{~mm}$. At the adapical end of the body chamber, the whorl height is $13 \mathrm{~mm}$, and the whorl thickness is $10.5 \mathrm{~mm}$.

This species compared with Phyllopachyceras theresae (Anderson) (1938, p. 141, pl. 12, figs. 4, 5) from California has a stouter whorl section, a smaller umbili- cus, and finer, denser ribbing. It is particularly characterized by its stout whorl section.

Type: Holotype USNM 130142.

Locality: USGS Mes. loc. 9492.

Genus HYPOPHYLLOCERAS Salfeld, 1924

\section{Hypophylloceras cf. H. californicum (Anderson)}

\section{Plate 11, figure 29}

One laterally crushed septate specimen bears ribbing similar to that on H. californicum (Anderson) (1938, p. 143, pl. 12, fig. 7), but the characteristics of that species are not known sufficiently to permit identification. H. onoense (Stanton) (1896, p. 76; Anderson, 1928 , p. 142, pl. 11, figs. 1, 2) has much finer ribbing.

Figured specimen: USNM 130132.

Locality: USGS Mes. loc. 9492. 
Genus CALLIPHYLIOCERAS Spath, 1927

Calliphylloceras nizinanum Imlay, n. sp.

Plate 11, figures 6-12

This species is represented by 20 specimens, of which most are small and septate. Whorls ovate in section, higher than wide, highly involute. Flanks gently convex, converging above to a rather narrowly rounded venter. Umbilicus extremely narrow; wall steep. Body chamber represented by three-fourths of a whorl.

Surface of shell covered with very fine striae that incline forward on the flanks in a gently flexous manner and arch forward on the venter. Surface of mold marked by sigmoidal constrictions that are barely evident at a diameter of $25 \mathrm{~mm}$, but become fairly strong adorally, and arch forward on the venter. Six constrictions are present on the body chamber. Fine lirae are visible only on the venter. The suture line is typical of the genus.

The small paratype shown on plate 11 , figures 10 and 11 , at a diameter of $33 \mathrm{~mm}$, has a whorl height of $19 \mathrm{~mm}$, a whorl thickness of $15 \mathrm{~mm}$, and an umbilical width of $3 \mathrm{~mm}$. On the holotype at a diameter of $46 \mathrm{~mm}$, the corresponding dimensions are 30,21 , and $4 \mathrm{~mm}$.

This species is distinguished from $C$. aldersoni (Anderson) (1938, p. 143, pl. 11, figs. 3-6) by its constrictions and growth striae arching forward more strongly on the venter, by lacking flexuous raised lines on the flanks, and by having a higher whorl section.

Types: Holotype USNM 130138. Paratype USNM 130139.

Locality: USGS Mes. loc. 9492.

\section{Calliphylloceras cf. C. aldersoni (Anderson)}

Plate 11, figs. $13-17$

Three specimens very closely resemble $C$. alderson $i$ (Anderson) (1938, p. 143, pl. 11, figs. 3-6) from California as far as their preservation and small size permit comparison. Their flanks converge rapidly toward a narrowly rounded venter and are covered with fine flexuous raised lines that arch forward gently on the venter, and the internal molds bear five flexuous constrictions.

Figured specimen: USNM 130161.

Locality: USGS Mes. loc. 9972.

Genus ANAGAUDRYCERAS Shimizu, 1934

Anagaudryceras aurarium (Anderson)

Plate 11, figures 18, 19, 24

Lytoceras (Kossmatella?) aurarium Anderson, 1938, Geol. Soc. America Spec. Paper 16, p. 151, pl. 20, figs. 1, 2.

This species is represented in the Chitina Valley by 28 specimens that agree very well with the original description and illustrations by Anderson except for the presence of very fine, forwardly inclined regularly spaced lirae. These are visible only on a few specimens in places where some of the shell is preserved.

Type: Plesiotype USNM 130154.

Localities: USGS Mes. locs. 2201, 8873, 9971, 14484, 14485. Fragments possibly belonging to this species occur at Mes. locs. $8880,9489,9950,9966$.

\section{Genus KoSSMATELLA Jacob, 1907 \\ Kossmatella cappsi Imlay, n. sp. \\ Plate 12, figures 17-22}

Three specimens of this species are on hand. Whorls in young stages depressed ovate and much wider than high, in adult specimens becoming subquadrate and higher than wide, embracing preceding whorls about two-fifths. Flanks on inner whorls strongly convex, rounding evenly into nearly rertical umbilical wall and into broadly rounded venter. Flanks on adult body chamber somewhat flattened, rounding fairly rapidly into steep umbilical wall and into moderately arched venter. Umbilicus moderate in width, wall steeply inclined to nearly vertical. Body chamber incomplete, represented by slightly more than half a whorl.

The entire surface of the shell is covered with fine forwardly inclined lines. In addition both shell and mold are marked by regular forwardly inclined constrictions that are most pronounced on the inner whorls and near the aperture of the adult body chamber. The constrictions on the inner whorls demarcate prominent lateral bulges that become much less prominent adorally on the penultimate whorl. The adult body whorl has 15 constrictions.

The suture line has fairly symmetrical bifid saddles and a bifid first lateral lobe.

At a diameter of $63 \mathrm{~mm}$, the largest specimen from Alaska has a whorl height of $29 \mathrm{~mm}$, a whorl thickness of $25 \mathrm{~mm}$, and an umbilical width of $20 \mathrm{~mm}$. At a diameter of $58 \mathrm{~mm}$ the same measurements are 25,22 , and $17 \mathrm{~mm}$ respectively.

The Alaskan specimens in general appearance are similar to Kossmatella agassizianum (Pictet) as figured by Jacob (1908, pl. 2, figs. 8-10) and differ mainly by having much weaker bulges and by their constrictions inclining adapically near the umbilicus. They show even greater resemblance to Kossmatella: gainesi (Anderson) (1938, p. 153, pl. 20, figs. 3-5) from California, from which they differ by the presence of lateral bulges on their inner whorls and by fewer constrictions. 
The species is named in honor of S. R. Capps in recognition of many years of study of Alaskan geology.

Tȳ̄es: Holotype USNM 130160. Parataypes USNM 130140.

Localities: USGS Mes. locs. 9492, 14514.

\section{Genus TETRAGONITES Kossmat, 1895}

Tetragonites aff. T. timotheanus (Pictet)

Plate 12, figures 24-28

Some Alaskan specimens of this genus differ from T. timotheanus (Pictet) (in Pictet and Roux, 1847, p. 39, pl. 2, figs. 6a-b, pl. 3, figs. 1a-c) by having parallel, instead of convergent flanks. They have been described in detail by Matsumoto (1959, p. 77-79, pl. 22, figs. 1a-c, 2a-c) in a paper dealing mainly with Cenomanian ammonites from the upper part of the Chitina Valley. In that paper most of the occurrences listed are from localities of late Albian to Cenomanian age, but Mesozoic locality 9492, which is either of early Albian or early middle Albian age, is also included. The specimens figured herein are all from Mesozoic locality 9492 .

Figured specimen: USNM 130131.

\section{Genus PTYCHOCERAS d'Orbigny, 1842}

Ptychoceras cf. P. laeve (Gabb)

Plate 12, figure 23

Two small internal molds show parts of two closely appressed limbs that belong mostly to the body chamber. The smaller limb is much depressed. The larger limb is nearly circular in section. The surface is nearly smooth, being marked only by faint growth lines and by several constrictions. The constrictions near the adoral end of the larger limb are bordered by a rounded rib that is most prominent on the venter.

These specimens differ from $P$. laeve (Gabb) (1869, p. 144, pl. 25, figs. 21, 21a, b) in being much smaller, but possibly belong to that species.

Figured specimen: USNM 130163.

Localities: USGS Mes. locs. 8872, 9972.

\section{Genus VALDEDORSELLA Breistroffer, 1947 \\ Valdedorsella? whiteavesi Imlay, n. sp. \\ Plate 11, figures 20-23, 25-28}

?Ammonites (sp. undet.). Whiteaves, 1876, Geol. Survey Canada Mesozoic Fossils, v. 1, p. 47, pl. 3, figs. 4, 4a.

Two small ammonites from the Chitina Valley greatly resemble a small ammonite from the Queen Charlotte Islands described by Whiteaves $(1876$, p. 47 , pl. 3, figs. 4, 4a) and are possibly identical. They have in common a broadly rounded, depressed whorl section, a small deep umbilicus, a rounded umbilical margin, and 6 or 7 sigmoidal constrictions that arch forward on the venter. On the specimens from the Chitina Valley, each constriction is posteriorly bordered by a low rounded rib that is slightly swollen at the umbilical margin. Also, a few weaker riblets occur on the venter between the constrictions.

The suture line is rather simple. Its saddles are slender and bifid; its first lateral lobe is trifid and slightly shorter than the ventral lobe; and its auxiliaries descend regularly to the umbilicus.

The holotype at a maximum diameter of $11.5 \mathrm{~mm}$ has a whorl height of $6.5 \mathrm{~mm}$, a whorl thickness of $8.5 \mathrm{~mm}$, and an umbilical width of $2 \mathrm{~mm}$.

Except for a broader whorl section V.? whiteavesi Imlay, n. sp. greatly resembles $V$. getulina (Coquand) as illustrated by Pervinquiere (1907, p. 154, pl. 6, figs. 16a-c) from beds near the Aptian-Albian boundary in Tunisia. V. hourcqi (Collingnon) (1937, p. 18, pl. 2, figs. $6,6 a, b, 7,7 a, b)$ from Madagascar is less depressed and has stronger ribbing and wider saddles, and its constrictions cross the venter nearly transversely instead of arching forward. $V$. akuschaensis (Anthula) (1899, p. 104, pl. 8, figs. 3a-c) from the Caucasus is more compressed and has wider saddles, but is difficult to compare because of its larger size.

The specimens from the Chitina Valley show some resemblances also to the upper Albian Puzosia chirichensis Pervinquiere (1907, p. 152, pl. 6, figs. 17-20), which species Breistroffer (1947, p. 60) assigns to Lunatodorsella, a subgenus of Desmoceras. That subgenus is distinguished, however, by a craterlike umbilicus, a rather sharp umbilical edge, and straighter constrictions.

The range of Valdedorsella, according to Wright (1956, L363), is Hauterivian to Aptian. Collignon (1937, p. 19) notes that $V$. getulina (Coquand) exists in both the Barremian and the Aptian of the Mediterranean region, but predominates in the Aptian. He notes that $V$. akuschaensis (Anthula) occurs in Aptian beds in the Caucasus and above the Aptian in the Clansayes beds in the province of Drôme in southern France.

This occurrence in the Clansayes beds is interesting because it indicates that the genus Valdedorsella ranges at least as high as the Aptian-Albian boundary. Whether the Clansayes beds are placed at the top of the Aptian (Breistroffer, 1947, p. 11-20) or at the base of the Albian (Spath, 1941, p. 668; Collignon, 1949, p. 109), they are not much older than the beds in the Chitina Valley, Alaska, that contain the lower Albian ammonites herein described.

Types: Holotype USNM 130145. Paratype USNM 130146. Locality: USGS Mes. loc. 9492. 
Genus CALLIZONICERAS Spath, 1923 Subgenus WOLLEMANNICERAS Breistroffer, 1947

Callizoniceras (Wollemanniceras) alaskanum Imlay, n. sp.

Plate 12, figures 11-16

The species is represented by six specimens. The holotype has been laterally crushed at the adapical end of the body whorl and slightly depressed at the adoral end. Shell small, moderately compressed. Whorls ovate depressed, becoming less depressed adorally, embracing about one-half of preceding whorls. Flanks convex, rounding evenly into broadly arched venter and into umbilical wall. Umbilicus moderate in width; wall steeply inclined at base. Body chamber on holotype is represented by threefifths of a whorl and appears to be nearly complete.

The ornamentation consists partly of gently flexous, rounded ribs of moderate strength that tend to fade on the venter. It includes some rather strongly flexuous, pronounced constrictions that arch forward on the venter and are bordered by flared ribs that are particularly prominent on the venter. The primary ribs begin low on the umbilical wall and incline forward to near the middle of the flanks where about half of them bifurcate. A few primary ribs bifurcate considerably below the middle of the flanks. All ribs, forked and single, curve forward strongly on the upper parts of the flanks, arch forward on the venter, and weaken ventrally. On the paratypes the ribs do not quite fade out on the venter. On the holotype the venter of the body chamber is nearly smooth except near the aperture where the ribbing becomes a little stronger. Tubercles are not present. Seven to eight constrictions occur on each whorl. The suture line is too poorly preserved to be traced.

The paratype (pl. 12, figs. 13, 14) at a diameter of $23 \mathrm{~mm}$ has a whorl height of $9 \mathrm{~mm}$, a whorl thickness of $11 \mathrm{~mm}$, and an umbilical width of $6.5 \mathrm{~mm}$. The holotype has a more compressed whorl section but has been somewhat deformed.

This species has the general appearance of Callizoniceras (Wollemanniceras) keilhacki Wollemann (1907, p. 36, pl. 5, figs. 4, 4a, 5, 5a ; Casey, 1957, pl. 7, figs. $4,4 \mathrm{a}, 5)$. It differs by having a more depressed whorl section, less flexuous constrictions and ribs, a greater number of forked ribs, and perhaps denser ribbing.

Types: Holotype USNM 130165. Paratypes USNM 130166a, b. Localities: USGS Mes. locs. 8873, 9976.

Callizoniceras (Wollemanniceras) fohlinense Imlay, n. sp.

Plate 12, figures 1-10

The species is represented by five specimens. Shell small, compressed. Whorls subquadrate, a little higher than wide, embracing about one-half. Flanks gently convex on inner whorls, becoming flattened during growth. Venter highly arched. Umbilicus moderate in width, shallow; wall low, steeply inclined on inner whorls, becoming vertical on outer whorls; umbilical edge evenly rounded on inner whorls, abruptly rounded on outer whorl. Body chamber unknown.

The ornamentation consists of thick, gently flexuous ribs and constrictions that incline forward on the flanks, arch forward strongly on the venter, and become progressively stronger and more flexuous during growth. On the smaller whorls (pl. 12, fig. 6) the ornamentation consists of rariably spaced unbranched ribs that begin low on the umbilical wall, are strong on the flanks, and nearly disappear on the venter. At a diameter of about $13 \mathrm{~mm}$ some short ribs are intercalated high on the flanks. At greater diameters many ribs branch near the middle of the flanks, others are indistinctly connected with secondary ribs, and a few remain unbranched. The ribs and constrictions on the venter are much weaker than on the flanks at all stages of growth, but become a little stronger during growth. Generally the ribs bordering the constrictions on the venter are a little stronger than the other ribs.

The suture line is simple. The auxiliaries do not descend toward the umbilicus as in Callizoniceras (Wollemanniceras) keilhacki Wollemann (1907, pl. 5, fig. 5a), but rather trend radially as in $C$. hoyeri (Von Koenen) (1902, pl. 38, fig. 6c).

The holotype at a diameter of $27 \mathrm{~mm}$ has a whorl height of $10.7 \mathrm{~mm}$, a whorl thickness of $9.5 \mathrm{~mm}$, and an umbilical width of $8 \mathrm{~mm}$.

This species compared with $C$. alaskanum Imlay, n. sp., has a subquadrate rather than a depressed ovate whorl section and has stronger more flexuous ribs. It bears much greater resemblance to the paratype of C. Keithacki (Wollemann) (1907, pl. 5, figs. 4a, 4b), but appears to have more forked ribs and a less rounded whorl section.

Types: Holotype USNM 130155. Paratypes USNM 130156. Locality: USGS Mes. loc. 14484.

\section{Genus MOFFITITES Imlay, 1959}

The original description of this genus is as follows:

This genus is characterized by an infiated shell, moderate involution, a whorl section that changes from ovate to coronate during growth, by flexuous ribs and constrictions that arch forward strongly on the renter, by frequent bifurcation of the primary ribs into somewhat weaker secondary ribs near the middle of the fianks, by a tendency of the secondary ribs to weaken and become striate as they near the middle of the venter, by the occurrence of flared ribs adjacent to the constrictions, and by having a desmoceratid suture line whose auxiliaries descend gradually toward the umbilical seam. 
It differs from the new genus Kenuicottia with which it is associated by being much more inflated, by having much stronger primary ribs, and by a tendency of its secondary ribs to become striate on the venter. Its ornamentation bears some resemblance to that of Pseudohaploceras Hyatt (1900, p. 500), but it is easily distinguished by having regularly furcating ribs and a coronate whorl section. It resembles T'aldedorsella Breistroffer $(1947$, p. 60$)$ in shape and involution, but the differentiation of its ribs into primaries and secondaries and the considerable strength of its primary ribs permit easy separation of the genera. The same features distinguish it readily from genera within the Holcodiscidae such as Astieridiscus Kilian (1910, p. 265).

The type species of Moffitites is Moffitites robustus Imlay, n. sp.

This genus is named for Fred $\mathrm{H}$. Moffit in recognition of his many important contributions to Alaskan geology as a member of the U.S. Geological Survey.

\section{Moffitites robustus Imlay}

Plate 13, figures $1-13$

Moffites robustus Imlay, 1959, Jour. Paleontology, v. 33, no. 1, p. 181-182, pl. 29, figs. 9-14.

The original description follows:

The species is represented by 30 specimens. Shell stout, moderate in size. Whorls ovate depressed, becoming stouter during growth, embracing about three-fifths. Flanks gently convex on immature specimens, becoming highly convex on adults. Venter highly arched in immature specimens, becoming broadly rounded on adults. Umbilicus moderate in width; wall inclined steeply, fairly high, rounding evenly into flanks. Body chamber incomplete, but represented by at least half a whorl.

The ribbing is gently fiexuous on the fianks, is arched forward on the venter, and is variable in density. The primary ribs are moderate in strength, are triangular in section, become stronger ventrally, and are generally narrower than the interspaces. They begin low on the umbilical wall, incline forward slightly on the wall and on the lower third of the flanks, and then recurve gently near the middle of the fianks where they pass into, or are replaced by much weaker secondary ribs.

On immature specimens some of the primary ribs bifurcate near the middle of the flanks. Others remain single on the fianks, but may be separated from each other, or from forked ribs by 1 or 2 secondary ribs that arise freely on the upper parts of the flanks. On the penultimate and body whorls most of the primary ribs bifurcate near the middle of the flanks and many of the pairs of secondary ribs are separated on the venter by 1 or 2 intercalated ribs. In many specimens the secondary ribs tend to weaken and become striate along the midventral area. but this tendency varies considerably from one specimen to another and from whorl to whorl. Tubercles are not present at any growth stage.

All whorls are marked by 6 to 8 constrictions that are fiexuous on the flanks and arch forward on the venters. The constrictions are inconspicuous on the immature whorls, but become more pronounced adorally. On the outer whorls the constrictions are generally bounded by 1 or 2 swollen primary ribs on the flanks and by a forwardly projected swelling on the venter.
The suture line is desmoceratid in plan. Its auxiliaries descend gradually toward the umbilical seam as in Desmoceras, Pseudohaploceras or Taldedorsella.

The holotype at a diameter of $97 \mathrm{~mm}$ has a whorl height of $43 \mathrm{~mm}$, a whorl thickness of $52 \mathrm{~mm}$, and an umbilical width of $31 \mathrm{~mm}$. At a diameter of $66 \mathrm{~mm}$ the other dimensions are 30 , 40. and $20 \mathrm{~mm}$ respectively. On paratype USNM $129875 \mathrm{~b}$ at a diameter of $56 \mathrm{~mm}$ the other dimensions are 24,37 , and $18 \mathrm{~mm}$ respectively.

Types: Holotype USNM 129874. Paratypes USNM 129875a, b, $129876 \mathrm{a}, \mathrm{b}$.

Occurrence: USGS Mes. locs. 2147, 2191, 8873, 8875, 8876, $8878,9489,9976 a, 9978,1471,14484,14485$. Fragments that possibly belong to this species occur at Mes. loc. 2173, 9971, and $\mathbf{1 + 4 6 7 .}$

\section{Moffitites crassus Imlay, n. sp.}

Plate 14, figures 3-7

This species is represented by three specimens. It differs from MLoffitites robustus Imlay, n. sp., by having a somewhat less depressed whorl section, much sparser, coarser ribbing, and fewer intercalated ribs on the upper part of the flanks, and the secondary ribs do not become striate on the venter. The holotype has 26 primary ribs and only 2 secondary ribs for each primary. Specimens of $M$. robustus Imlay at a comparable size have from 33 to 35 primary ribs and a little more than 2 secondary ribs for each primary.

The holotype at a diameter of $35.5 \mathrm{~mm}$ has a whorl height of $16.5 \mathrm{~mm}$, a whorl thickness of $16.5 \mathrm{~mm}$, and an umbilical width of $8.5 \mathrm{~mm}$. The suture line is not preserved.

Types: Holotype USNM 130175. Paratype USNM 130176.

Localities: USGS Mes. locs. 8878, 14477, 14487.

Genus FREBOLdICERAS Imlay, 1959

The original description is as follows:

This genus resembles Callizoniceras Spath (1923, p. 35) from the upper Barremian to lower Albian of Europe (Von Koenen, 1902 , p. 58, pl. 9, figs. 5a-c. p. 60, pl. 28, figs. 5a, b, 6a-c, 7 ; Wollemann, 1907, p. 36, pl. 5, figs. 4, 4a, 5, 5a ; Brinkman, 1937, p. 8-10, figs. 4.5$)$. It differs by being more involute; by its whorl section being higher and more narrowly rounded; by its primary ribs being more regularly-spaced, more swollen, and confined generally to the lower part of the flanks; by its constrictions being less regularly-spaced; and by having fewer secondary ribs. Its smooth body chamber and large size may be other distinctions. Its suture is very simple and closely resembles that of Callizoniccras. The type species of Freboldiceras is Freboldiceras singulare Imlay, n. sp.

\section{Freboldiceras singulare Imlay}

Plate 14, figures 8-17

Freboldiceras singulare Imlay, 1959, Jour. Paleontology, v. 33, no. 1 , p. 182, 183, pl. 30, figs. 1-7.

The original description is as follows:

Four specimens of this species have been found in the Talkeetna Mountains at one locality. Shell compressed, discoidal. 
Whorls subovate in section, considerably higher than wide, thickest near umbilicus, embracing about two-thirds. Flanks gently convex in their lower parts, but tapering above to a narrowly rounded venter. Umbilicus fairly narrow, wall steeply inclined, rounding evenly into flanks. Body chamber represented by at least three-fiftlis of a whorl.

The ornamentation of the septate parts of the shell consist mostly of prominent, flexuous, regularly-spaced primary ribs, of deep, irregularly-spaced constrictions, and of flexuous striae. The primary ribs begin high on the umbilical wall, incline forward and become swollen near the umbilical edge, and then curve forward near the middle of the flanks where most of them pass into bundles of striae that arch forward gently on the flanks and venter. The primary ribs that adjoin constrictions continue across the flanks and venter, but are more prominent on the internal mold than on the shell. Some specimens at a few places have single, short secondary ribs that are intercalated between the primary ribs and continue across the venter. Where shelly material is preserved its surface is covered with fine. flexuous striae that is coarser on the primary ribs than on the interspaces. The periphery of the internal mold is strongly undulating. Wherever the shell is preserved the periphery is nearly smootl.

The adult body chamber is nearly smooth. Faint flexuous striae are present in a few places where shell layers are present. On the penultimate whorl the primary ribs become much weaker adorally and are barely visible near the last-formed septa.

The suture-line is very simple. It greatly resembles that of the genus Catlizonicras (Wollemann, 1907, pl. 5, fig. 5a; V. Koenen, 1902, pl. 9, fig. 5c, pl. 38, figs. 6, 7 ; Chaput, 1920, pl. 1. figs. $4 a, b)$ in its broad first lateral saddle, in its first lateral lobe being slightly deeper than the ventral lobe, and in its auxiliary saddles not being retracted adapically near the umbilicus. In fact the auxiliaries ascend slightly as they apuroach the umbilical seam.

The holotype at a diameter of $55 \mathrm{~mm}$, has a whorl height of $24 \mathrm{~mm}$, a whorl thickness of $19 \mathrm{~mm}$ and an umbilical width of $14 \mathrm{~mm}$.

This species resembles Lemuroceras irenense McLearn (1945, pl. 5, fig. 5, 1948, p. 2) from the Moosebar formation of British Columbia, and probably belongs in the same genus. The preservation of the holotype of $L$. irenense is not sufficient, however, to prove whether the resemblances are accidental or reflect generic relationships.

Types: Holotype USN 129868. USNM 129869a-c.

Occurrence: USGS Mes. loc. 24877.

\section{Genus KENNICOTTIA Imlay, 1959}

The original description is as follows:

This genus is characterized by being fairly involute, by the presence of persistent primary ribs that bifurcate fairly regularly near the middle of the flanks, by having flexuous ribs and constrictions that arch forward strongly on the venter, by the presence of some flared ribs adjoining the constrictions, by reduction of the secondary ribs along the midline of the venter. and by its suture line having regularly descending auxiliary lobes. It shows resemblance to Pseudohaploceras Hyatt (1900. p. 570) in amount of involution, whorl shape, suture-line, presence of flexuous constrictions and ribs, and presence of bifurcating ribs. It differs. however, by having a more subquadrate whorl section, a rertical umbilical wall, flatter flanks, weaker constrictions and flared ribs, and stronger, more regularly bifurcating primary ribs. It differs from Taldedorsella (Briestroffer, $1947, \mathrm{p} .60)$ in its whorl section being subquadrate instead of round and by the presence of bifureating ribs. It differs from Puñsia by being considerably more involute, by the presence of bifurcating prinary ribs, and by the auxiliary lobes of its suture line descending regularly instead of abruptly. The type species of Kennicottia is Kennicottia bifurcata Imlay, n. sp.

\section{Kennicottia bifurcata Imlay}

Plate 15, figures 1-6

Kenicottia bifurcata Imlay, 1959, Jour. Paleontology, v. 33, n. 1. p. 183,184 , pl. 30 , figs. $8-13$.

The original description is as follows:

This species is represented by 13 specimens. Whorls subovate in immature specimens. becoming subquadrate in adult, embracing about three-fiftlis. Flanks gently convex, becoming less so during growth, rounding into highly arched venter. Umbilicus fairly narrow; wall low, vertical at base, rounding evenly into flanks. Body chamber unknown.

The ribbing is gently flexuous on the flanks and arched forward strongly on the venter. The primary ribs are somewhat stronger than the secondary ribs. They begin low on the umbilical wall, are highest on the edge of the wall and become rather broad ventrally. Most primary ribs bifurcate near the middle of the flanks, but some remain single, and some are indistinctly connected with secondary ribs. The secondary ribs are reduced in strength along the midline of the venter.

From 6 to 7 weak flexuous constrictions occur per whorl. They become more conspicuous adorally and are most conspicuous on the venter. On the adoral part of the holotype, they are bounded by swollen ribs.

The suture line is desmocerated in type. Its regularly descending auxiliary lobes contrast with the retracted auxiliaries in Puzosia, but are comparable with those in Pseudohaploceras.

The holotyle at a diameter of $63 \mathrm{~mm}$ has a whorl height of $29 \mathrm{~mm}$, a whorl thickness of $25 \mathrm{~mm}$, and an umbilical width of $15 \mathrm{~mm}$.

This species has a general resemblance to Puzosia subquadrata Anderson (1938, p. 186. pl. 45, figs. 3-5) from California, but differs by having much stronger primary ribs that bifurcate fairly regularly, by its ribbing being less flexuous, by its umbilical wall rounding more evenly into the flanks, and by its anxiliary lobes descending much more gradually toward the umbilical seam (compare Anderson. 1938. p. 183, text, fig. 3 , no. 6).

Types: Holotype USNM 129870. Paratype USNM 129871. Occurrence: CSGS Mes. locs. 8873, 9972, 14471, 14484.

\section{Kennicottia rugosa Imlay, n. sp.}

Plate 1.5, figures $7-13$

The species is represented by three specimens. Shell fairly large for genus, moderately compressed. Whorls subquadrate in section, becoming stouter during growth, embracing about three-fifths of preceding whorls. Flanks gently convex, becoming less so during growth, rounding evenly into broadly arched venter. Imbilicus fairly narrow; wall moderate in height, vertical at base, inclined above, and rounding 
rather abruptly into flanks. Body chamber incomplete, but represented by at least half a whorl.

The ribbing is flexuous on the flanks, arched forward on the verter, and somewhat reduced in strength along the midventral lines. The primary ribs begin at the umbilical seam, and incline forward gently on the lower part of the flanks, and generally divide near the middle of the flanks into pairs of weaker secondary ribs that arch forward considerably. Some secondary ribs are indistinctly connected with the primary ribs, and some arise freely above the middle of the flanks.

About 8 to 9 flexuous constrictions occur on each whorl. These constrictions are inconspicuous on the smaller whorls, but become more prominent during growth. Some constrictions on the penultimate and body whorls are bounded by swollen ribs that on the venter may become flared.

The suture line is poorly preserved and cannot be traced.

The holotype at its adoral end has a whorl height of $58 \mathrm{~mm}$ and a whorl thickness of $51 \mathrm{~mm}$. The paratype shown on plate 15 , figures $7,8,11$, at a diameter of $42 \mathrm{~mm}$, has a whorl height of $20.5 \mathrm{~mm}$, a whorl thickness of $18 \mathrm{~mm}$, and an umbilical width of $10 \mathrm{~mm}$.

This species is distinguished from any species of Puzosia by being more involute and by having persistent primary ribs of which most divide near the middle of the flanks. It differs from $K$. bifurcata Imlay, n. sp., by having a stouter whorl section, coarser, sparser ribbing, and a more abruptly rounded umbilical edge.

Types: Holotype USNM 130152. Paratypes USNM 130153a, b. Localities: USGS Mes. locs. 9489, 14485.

\section{Genus PUZOSIA Bayle, 1878}

Puzosia alaskana Imlay, n. sp.

Plate 16, figures 1-13

The species is represented by about 90 specimens. Whorls elliptical in section, higher than wide, widest near the umbilicus, embracing about one-half of preceding whorls. Flanks flattened, converging slightly toward the highly arched venter. Umbilicus moderate in width; wall steeply inclined in early growth stages, becoming vertical in adult, rounding evenly into flanks in early stages, but abruptly in adult. Body chamber represented by three-fifths of a whorl.

The ornamentation on immature specimens consists of strongly flexuous striae, riblets, and constrictions that arch forward considerably on the venter. They curve forward on the umbilical wall and base of the flanks, curve backward slightly below the middle of the flanks, and then curve forward strongly on the upper part of the flanks. The riblets are most pronounced on the venter and upper parts of the flanks, but many of the constrictions are bounded on one, or on both, sides by riblets that begin at the umbilical margin. The constrictions number from 6 to 7 per whorl and are much more conspicuous on the internal molds than on the shell.

During growth the constrictions become more deeply impressed and more strongly arched on the venter. The ribbing weakens on the lower part of the flanks, but becomes stronger on the venter and on the upper part of the flanks. On the adult body chamber there are from 18 to 12 ribs between successive constrictions. Generally the ribs bordering the constrictions on the venter are somewhat swollen.

The suture line descends fairly rapidly toward the umbilicus. It is characterized by the second lateral saddle being a little higher than the first lateral saddle. This feature occurs in the genus Melchiorites as figured by Fallot $(1920$, p. 255-257) as well as in Puzosia (see Spath, 1923, pl. 2, fig. 3e).

The holotype at a diameter of $41 \mathrm{~mm}$ has a whorl height of $17 \mathrm{~mm}$, a whorl thickness of $13 \mathrm{~mm}$, and an umbilical width of $13.5 \mathrm{~mm}$. The same dimensions of the small paratype shown on plate 16 , figure 11 , are $29,12,10$, and $8.5 \mathrm{~mm}$, respectively.

This species shows resemblances with the genera Melchiorites, Puzosia, and Hulenites. In lateral view it resembles Puzosia quenstedti Parona and Bonarelli (1897, p. 81, pl. 11, figs. 3a, b) from the Albian of Europe, but its ribs and constrictions arch forward much more on the venter, and it develops an abrupt instead of an evenly rounded umbilical edge. The pattern of its ornamentation and the shape of its umbilical edge is so similar to that of Hulenites reesidei (Anderson, 1938, p. 187, pl. 38, figs. 2, 3) from the late Aptian to early Albian of California as to suggest that the two species are closely related. It may be distinguished from $H$. reesidei, however, by being more compressed, by having more projected ornamentation on the venter, by its ribs showing no tendency to fade on the venter, and by the ribs on the immature whorls being much finer and more flexuous. It also shows considerable resemblance to ribbed species of Melchiorites-such as $M$. indigenes Anderson (1938, p. 184, pl. 67, fig. 3, pl. 68, fig. 2) from the Aptian of California, but it is distinguished by developing an abrupt umbilical edge and finer, denser, more sigmoidal ribbing.

Types: Holotype USNM 130143. Paratypes USNM 130144. Locality: USGS Mes. loc. 9492. 


\section{Genus BEUdANTICERAS Hitzel, 1905}

Beudanticeras glabrum (Whiteaves)

Plate 16, figures 14-21

Placenticcras glabrum Whiteaves, 1889, Contr. to Canadian Paleontology, v. 1, pt. 2, p. 172, pl. 24, figs. 1, 1a, b.

Desmoceras affine var. glabrum Whiteaves, 1893, Royal soc. Canada, 1st ser., v. 10, p. 115, pl. 9.

Beudanticcras glabrum (Whiteaves). McLearn, 1931, Royal Soc. Canada, Trans., ser. 3, v. 25, sec. 4, p. 3.

?Beudanticcras cf. B. glabrum. Whiteaves. McLearn, 1945, Geol. Survey Canada Paper 44-17 (2d ed.), pl. 4, figs. $2,3$.

Beudanticeras glabrum (Whiteaves). Warren, 1947, Jour. Paleontology, v. 21, p. 121, pl. 30, figs. 1-4.

Nine specimens of Beudanticeras, obtained in the Talkeetna Mountains, very closely resemble the original type specimen described by Whiteaves in their narrowly rounded whorl section, very narrow umbilicus, broad asymmetrical first lateral lobe, low, broad saddles, and numerous auxiliary lobes. Furthermore, five of the specimens are nearly as smooth as the type, being marked only by fine flexuous striae that are barely visible under oblique lighting. The other four differ from the type, however, by having riblets and weak bulges on the flanks. In addition several of the specimens bear one or more weak constrictions per whorl.

The presence of striae and riblets on some of the specimens from the Talkeetna Mountains agrees with the observations of Warren (1947, p. 121) based on specimens of Beudanticeras glabrum (Whiteaves) from the Lower Mackenzie River valley in Canada. In his specimens, however, the ornamentation is most conspicuous near the umbilical border and constrictions are absent.

These differences are probably not of specific value considering that the number and strength of constrictions is a variable characteristic in many species of Beudanticeras, that the determination of the presence of weak constrictions may be difficult on poorly, preserved specimens, and that the distribution of riblets on the flanks may reflect individual variations. The fact that most of the specimens from the Talkeetna Mountains agree very well in their characteristics with the holotype of $B$. glabrum (Whiteaves) is herein given more weight than the minor differences in ornamentation mentioned above.

This species is characterized by its umbilicus being narrower and its saddles broader and lower than in most species that have been assigned to the genus Beudanticeras. The narrowness of the umbilicus is comparable, however, with that of $B$. sutherlandi (Etheridge) (Whitehouse, 1928, p. 202, pl. 25, fig. 4) from Australia, which species differs from B. glabrum. by its stouter whorls. Furthermore the sutural pattern is similar to that in B. 7aevigatum (J. de C. Sowerby) (Spath, 1223, p. 56) from England; this species differs by its wider umbilicus and stouter whorls. Because of these similarities $B$. glabrum is herein considered as belonging within the range of variation of Beudanticercs, although possessing peculiar characteristics somewhat different from typical species of Beudanticeras in Europe. The differences are no greater than among certain .Jurassic ammonites from western North America that Arkell (in Arkell and Playford, 1954, p. 596-597) assigns to genera based on European species even though they possess certain features that are not characteristic of the types.

Type: Plesiotypes USNM 130149.

Locality: USGS Mes. loc. 24877.

Subgenus GRANTZICERAS Imlay, 1960

Beudanticeras (Grantziceras) multiconstrictum Imlay

Plate 14, figures 1,2

Beudanticeras (Grantwiceras) multiconstrictum Imlay, 1960, U.S. Geol. Survey Prof. Paper 335 (in press).

This species is characterized by many regularly spaced falciform constrictions, by broadly bundled striae on its flanks, and by a scaphitoid body chamber. Its largest specimens are considerably larger than any described European species of Beudanticeras, but are only about half as large as $B$. affine (Whiteaves) from Canada and northern Alaska. It resembles $B$. affine more closely than any other described species of Beudanticeras. but differs by having nearly twice as many constrictions per whorl, a somewhat wider umbilicus, a shorter second lateral lobe, and a more compressed whorl section.

Types: Holotype USNM 128721. Paratypes USNM 128722, 128723.

Loralitics: USGS Mes. locs. 24877, 25320, 25329.

\section{Genus BREWERICERAS Casey, 1954}

\section{Brewericeras breweri (Gabb)}

Plate 17 . figures $5-10,12,13$

Ammonites breteri Gabb, 1864, Paleontology Calif. v. 1, p. 62, pl. 10, fig. 7 .

Gabb, 1869. Gabb, Paleontology Calif., v. 2, p. 130, pl. 19, fig. 5b. pl. 20, fig. 5 .

Gabb. Whiteaves, 1876, Geol. Survey Canada Mesozoic Fossils, v. 1, p. 21, pl. 1, figs. 2, 2a, 3, 3a.

Beudanticeras breweri (Gabb). Anderson, 1938, Geol. Soc. America Spec. Paper 16, p. 189, pl. 43, fig. 3, pl. 44, figs. $1,2$.

Brewerimeras bremeri (Gabb). Casey, 1954. Washington Acad. Sci. Jour., v. 44, no. 4, p. 112.

The 13 Alaskan specimens of this species on hand are all compressed, have flattened flanks, a highly arched venter, a vertical or nearly vertical umbilical 
wall, and a fairly sharp umbilical rim. They all develop sigmoidal ribs that bear extremely weak, forwardly inclined swellings at the umbilical edge, that are prominent and sparse on the upper part of the flanks, and are reduced in strength on the venter and on the lower parts of the flanks. They show considerable variation, however, in strength of ribbing and in the stage of growth at which ribs first appear. In some specimens sigmoidal ribs appear at a diameter as small as $20 \mathrm{~mm}$. In other specimens ribs first appear at a diameter of $50 \mathrm{~mm}$. The costate parts of internal molds bear constrictions that are conspicuous only on the venter. The suture line is similar to that of the genus Beudanticeras.

Type: Plesiotype USNM 130133.

Locality: USGS Mes. loc. 9492.

Brewericeras of. B. hulenense (Anderson)

Plate 17, figures $11,1+-16$

Beudanticeras hulenense Anderson, 1938, Geol. Soc. America Spec. Paper 16, p. 190 , pl. 44, figs. 3,4 .

Brewericeras hulenense (Anderson). Casey, 195t, Washington Acad. Sci. Jour., v. 44, no. 4, p. 112.

Associated with B. breweri (Gabb) at Mesozoic locality 9492 are some ammonites that are possibly only a smooth variant of that species. They differ, however, by having a smaller umbilicus, slightly flatter flanks, and much weaker, finer ribbing that develops at a later growth stage. In addition the larger specimens have a slightly raised umbilical rim. These specimens have hitherto been assigned to "Ammonites" haydeni Gabb (Martin, 1926, p. 346; Moffit 1938, table opposite p. 80; Imlay and Reeside, 1954, p. 229), but their whorl sections compare in stoutness with those of $B$. hulenense (Anderson) (1938, pl. 44, fig. 4) rather than with those of B. haydeni (Gabb) (1864, p. 62, pl. 10, fig. 8a), which has similar weak ornamentation.

Figured specimens: USNM 130130, 130159.

Localities: USGS Mes. loc. 9492, 14514.

\section{Genus DESMOCERAS Zittel, 1884}

Desmoceras? sp. juv.

Plate 17, figures $1-1$

The species is represented by one internal mold. The specimen is small and has a subquadrate whorl section. At a diameter of $26 \mathrm{~mm}$, its whorl height is $13 \mathrm{~mm}$, its whorl thickness is $14 \mathrm{~mm}$ and its umbilical width is $4 \mathrm{~mm}$. The adoral part of the internal mold is marked by two conspicuous gently flexuous constrictions that arch forward slightly on the venter. Between the constrictions on the venter are faint riblets. The suture line is typical of Desmoceras.
This species differs from D. voyi Anderson (1938, p. 180, pl. 40, figs. 4-8) by having a subquadrate instead of an ovate whorl section. It is so much smaller than the figured specimens of $D$. merriami (Anderson) (1902, p. 103 , pl. 6 , figs. $135-138 ; 1938$, p. 181 , pl. 43 , figs. 1,2 ) that comparisons with that species would be meaningless.

Figured specimen: USNM 130135.

Locality: USGS Mes. loc. 9492.

\section{Genus PARASILESITES Imlay, 1959}

The original description (Imlay, 1959, p. 184) is as follows:

This genus is characterized by its fairly evolute shell, wide, shallow umbilicus, strongly flexuous ribs and constrictions, presence of umbilical bullae, occasional rib furcation on the flanks, and by the auxiliaries of its suture line descending only slightly. It differs from the Barremian genus silesites by the presence of umbilical bullae, by the furcation of some ribs low on the flanks, by the ribs being inclined forward strongly at the edge of the umbilicus, and perhaps by its auxiliaries not curving adorally. It differs from the upper Aptian-lower Albian genus Neosilesites by the presence of umbilical bullae, by its ornamentation being much more sigmoidal, by its ribs branching much lower on the flanks, and by its primary ribs not splitting into many fine secondary ribs on the upper parts of the flanks. The suture line of Parasilesites is similar to that on small specimens of Silesites and Neosilesites (Fallot 1920a, p. 54,$55 ; 1920 \mathrm{~b}$, p. 209-213). The tendency in the Silestidae (Wright, 1957, p. L372) for the auxiliaries to curve forward in advance of the first saddle, as illustrated by Uhlig (1883, pl. 18, figs. 11-14), does not bar Parasilesites from that family considering that the tendency, as discussed by Fallot (1920b, p. 209) is general only among adults. The type species of Parasilesites is Parasilesites bullatus Imlay, n. sp.

\section{Parasilesites bullatus Imlay}

Plate 18 , figure $1-8$

Parasilesites bullatus Imlay, 1959, Jour. Paleontology, v. 33, no. 1, p. 181 , pl. 29 , figs. 1-8.

Only two specimens of this species are known. Whorls ovate in section, a little higher than wide, embracing about two-fifths. Flanks gently convex, rounding evenly into highly arched venter. Umbilicus fairly wide, shallow; umbilical wall low, steeply inclined, rounding evenly into flanks. Body chamber incomplete, represented by at least half a whorl.

The innermost whorls, exposed in the umbilicus of the type specimens, are marked by 7 or 8 deep, forwardly inclined constrictions and by faint forwardly inclined riblets. On the penultimate whorl the riblets are a little stronger and more flexuons, and number from 5 to 7 between successive constrictions. Those riblets adjoining constrictions are a little larger than the others and some of them bear weak bullae near the umbilical margin. On the body whorl both constrictions and ribs become stronger. many ribs are bullate, and some rib branching occurs at the bullae. On both the penultimate and body whorls the ribs and constrictions arch forward on the renter and most of the ribs are somewhat weakened on the venter. The venter of the internal mold at the beginning of the 
body chamber bears a distinct groove that has a length of only $8 \mathrm{~mm}$. The ribs end abruptly at this groove and some terminate in swellings. The groove may represent a deformity and probably is not of specific importance.

The suture line is very simple. Its auxiliaries descend only slightly toward the umbilical seam. The ventral lobe is nearly as long as the first lateral lobe.

The holotype at a diameter of $27 \mathrm{~mm}$ has a whorl height of $9 \mathrm{~mm}$, a whorl thickness of $8 \mathrm{~mm}$, and an umbilical width of $11.5 \mathrm{~mm}$.

The species is characterized by developing distinet umbilical bullae, by having fairly regularly-spaced constrictions and ribs, and by some of the ribs bifurcating from the bullae. The small paratype resembles Silesites puzosiaformis Anderson (1938, p. 191, pl. 20, figs. 9, 10) from the early Albian of California, but is stouter, has coarser ribbing, more and deeper constrictions, and bears weak umbilical bullae.

Types: Holotype USNM 129872. Paratype USNM 129873. Occurrence: USGS Mes. loc. 9492.

\section{Parasilesites irregularis Imlay, n. sp.}

Plate 18, figures 9-17

This species is represented by three specimens. Shell compressed, discoidal. Whorls subquadrate in section, higher than wide, embracing about one-third. Flanks flattened, rounding evenly into moderately arched venter. Umbilicus fairly wide, shallow; wall low, steeply inclined, rounding evenly into flanks. Body chamber represented by at least half a whorl. Aperture sinuous and has a pronounced ventral projection.

The ornamentation of the septate whorls, exposed in the umbilicus of the holotype, consists of 9 deep, flexuous constrictions between which lie from 2 to 5 prominent, irregularly spaced, single flexuous ribs. The ribs adjoining the constrictions are somewhat stronger than the other ribs and many of them are swollen on the umbilical edge. Both constrictions and ribs weaken considerably on the venter and arch forward gently on the venter.

On the flanks of the body chamber the constrictions and ribs become more flexuous, stronger, and more irregularly spaced. Many of the ribs are distinctly bullate at the umbilical edge. On the venter both constrictions and ribs arch forward strongly, the constrictions are narrow and deep, and the ribs are highly variable in strength. Most of the ribs bordering the constrictions on the venter are swollen. Between these ribs are bundles of riblets or striae that arise from the flank ribs on the margin of the venter and tend to fade out on the venter or to pass into swollen ribs.

The suture line is very simple, and its auxiliaries descend only slightly toward the umbilicus.

The holotype at an estimated diameter of $24 \mathrm{~mm}$ has a whorl height of $8 \mathrm{~mm}$, a whorl thickness of $7 \mathrm{~mm}$, and an umbilical width of $10 \mathrm{~mm}$.
The presence of umbilical bullae readily distinguish this species from all species of Silesites, but its irregular ribbing bears some resemblance to that of $S$. vulpes (Coquand) as figured by Uhlig (1883, p. 111, pl. 18, figs. 8, 9) from the Barremian of the Carpathian Mountains.

Types: Holotype USNM 130147. Paratypes USNM 130148. Locality: USGS Mes. loc. 9492.

\section{Genus HULENITES Matsumoto, 1955}

Hulenites cf. H. reesidei (Anderson)

Plate 18, figures 18-21

The genus Hulenites (Matsumoto, 1955, p. 122) is represented in the Chitina Valley by 4 specimens, of which 1 is much smaller than the other 3. Shell compressed, discoidal. Whorls ovate in section, higher than wide, becoming higher during growth, embracing about one-half preceding whorls. Flanks gently convex, becoming flatter during growth, rounding evenly into highly arched venter. Umbilicus moderately wide, shallow; umbilical wall low, vertical at base, rounding rather abruptly into flanks. Body chamber incomplete, represented by at least half a whorl.

The inner whorls, exposed in the umbilicus, bear many deep, forwardly inclined constrictions, but otherwise are smooth. The outer whorl of the smaller figured specimen has nine flexuous constrictions that arch forward strongly on the venter and become more deeply impressed during growth. Weak, forwardly inclined riblets are barely visible on the upper part of the flanks and on the venter. The outer whorl of the larger specimens bears constrictions that are deep near the umbilicus and shallow on the venter. Between successive constrictions are from 7 to 12 fine, forwardly inclined ribs that begin below the middle of the flanks, arch forward on the venter, and weaken along the midventral line. Some of the ribs bordering the constrictions are swollen.

The suture line cannot be traced accurately.

The larger specimen illustrated at a diameter of 33 mm has a whorl height of $13.5 \mathrm{~mm}$, a whorl thickness of $11 \mathrm{~mm}$, and an umbilical width of $12 \mathrm{~mm}$.

The largest specimens from the Chitina Valley are comparable in size with the small paratype of Hulenites reesidei (Anderson) (1938, p. 187, pl. 38, fig. 3) from California. They appear to have finer ribbing, a stouter whorl section, and a wider umbilicus. As these differences are all minor and as the range of variation in $H$. reeside $i$ (Anderson) is unknown, the establishment of the Alaskan specimens of Hulenites as a distinct species does not seem justified at present.

Figured specimen: USNM 130134.

Localities: USGS Mes. loc. 9480, 9492, 14466. 
Genus CLEONICERAS Parona and Bonarelli, 1896

Cleoniceras overbecki Imlay, n. sp.

Plate 19, figures $36-39$

One small specimen of Cleoniceras has been found in the Chitina Valley. Whorl compressed, much higher than wide, widest at umbilical edge, embracing about three-fourths of preceding whorls. Flanks flat, converging from umbilical edge to narrowly rounded venter. Umbilicus narrow; wall low, vertical at base, steeply inclined above, rounding abruptly into flanks. Body chamber unknown.

The umbilical edge bears 15 weak bullae that become weaker adorally. From these bullae pass weak, slightly flexuous ribs that incline forward on the flanks and arch forward on the venter. Some ribs remain single, but many bifurcate on the lower third of the flanks. Other ribs arise freely between the lower third and the middle of the flanks. All ribs become stronger ventrally, but are reduced somewhat in strength along the midventral line. There are 42 ribs on the upper part of the flanks, or nearly 3 secondary ribs for each primary.

The suture line cannot be traced. The figured specimen at a diameter of $38 \mathrm{~mm}$ has a whorl height of 18 $\mathrm{mm}$, a whorl thickness of $10 \mathrm{~mm}$, and an umbilical width of $7.5 \mathrm{~mm}$.

The Alaskan species somewhat resembles the small specimen of Cleoniceras cleon (d'Orbigny) (1841, pl. 84, fig. 3) from France. That species, however, judging from a plaster replica of a typical specimen furnished by Raymond Casey of the British Geological Survey, has more prominent bullae and much stronger, more flexuous ribs. C. bicurvatoides (Sinzow) (1909, p. 29, pl. 2, figs. 7-18) from southern Russia has much more flexuous ribs and less prominent umbilical bullae. C. baylei (Jacob) at a comparable size, as figured by Spath $(1925$, p. $93 ; 1923$, pl. 4, figs. $6 \mathrm{a}, \mathrm{b})$, has a much stouter whorl section. $C$. leightonense Spath (1942, p. 701, 702, text fig. 247) is similar in shape and ornamentation, but is not strictly comparable because of the much greater size of the type. The adoral weakening of the ribs and bullae on the Alaskan species indicates that it loses its ornamentation at a much smaller size than does $C$. leightonense Spath.

The Alaskan specimen is the only one yet described from the Pacific coast of North America that fits the definition of Cleoniceras in all particulars. As its characteristics do not match those of the described species of Cleoniceras from Eurasia, it is deemed worthy of specific rank even though its adult characteristics are unknown.
This species is named in honor of R. M. Overbeck, who collected many of the ammonites from the Chitina Valley described herein.

Type: Holotype USNM 130141.

Locality: USGS Mes. loc. 9492.

\section{Genus PUZOSIGELLA Casey, 1954}

Puzosigella cf. P. rogersi (Hall and Ambrose)

Plate 19, figures 33-35

Three specimens from the Chitina Valley probably belong to "Sonnratia" rogersi Hall and Ambrose (1916, p. 69) as interpreted by Anderson (1938, p. 197, pl. 20, figs. 6,7$)$. They are closely similar to the small plesiotype figured by Anderson on his plate 20, figure 6, but differ from the larger specimen figured by Anderson by losing their umbilical bullae at an earlier growth stage and by having finer, more closely spaced secondary ribs. Such differences appear to be normal for the species judging from the specimens in the Geological Survey collections from Oregon and California. As these collections show that the genus Puzosigella is characterized by considerable variability, the validity of the species discussed by Anderson should be established thoroughly before additional species are described. The Alaskan specimens may represent a distinct species from any described, but such cannot be proved now. The presence of the genus Puzosigella in Alaska is itself of stratigraphic importance as Puzosigella in California and Oregon is restricted to beds of early Albian age.

Figured specimen: USNM 130168.

Locality: USGS Mes. loc. 8877.

\section{Genus LeCONTEITES Casey, 1954}

This genus includes shells that are compressed and moderately involute and that develop a vertical umbilical wall. The shell is marked by flexuous ribs that are arched forward considerably on the venter and are reduced in strength along the midventral line. Bifurcation near the middle of the flanks is common. Weak flexuous constrictions that may be bordered by flared ribs on the venter are more evident on the internal mold than on the shell. The most finely ribbed species develop a sharp umbilical rim and weak umbilical bullae. The more coarsely ribbed species develop an abruptly rounded umbilical rim and more or less swollen primary ribs. The genus Puzosigella Casey (1954, p. 110) differs from Leconteites mainly by having more prominent umbilical bullae, by the flanks ribs originating in bundles at these bullae, and by possessing many, rather conspicuous, narrow constrictions on immature specimens. 
Leconteites modestus (Anderson)

Plate 19, figures 4-6

Cleoniceras modestum Anderson, 1938, Geol. Soc. America Spec. Paper 16, p. 193, pl. 50, figs. 2-4.

This species is represented in the Chitina Valley by three specimens that compare closely in shape and ribbing with the paratypes from California figured by Anderson on his plate 50, figures 3 and 4 . They all differ from the type specimens of $L$. lecontei (Anderson) $(1938$, p. 192 , pl. 38 , fig. 4 , pl. 47 , figs. $3-5)$ by having weaker less flexuous ribs and less conspicuous umbilical tubercles. However, collections on hand from California and Oregon suggest that $L$. modestus is merely a smooth variant of $L$. lecontei. This matter cannot be settled until larger collections are available. Illustrations of L. lecontei (Anderson) are shown on plate 19, figures $1-3$, for comparison with the Alaskan specimens of $L$. modestus (Anderson) and $L$. deansi (Whiteaves) described herein.

Type: Plesiotypes USNM 130172, 130173.

Localities: USGS Mes. loc. 9971, 11389.

\section{Leconteites deansi (Whiteaves)}

Plate 19, figures 7-14

Olcostephanus (Astieria) deansi Whiteaves. 1893, Canadian Record Science p. 442-444, pl. 7, figs. 1, 1a.

The species is represented by 35 specimens. Shell small, discoidal, compressed. Whorls subovate, higher than wide, embracing about three-fifths. Flanks flattened below, converging slightly above to narrowly round venter. Umbilicus fairly narrow; wall low, vertical, rounding rather abruptly into flanks on inner whorls, but developing a rim on adult body chamber. The body chamber represents about three-fifths of a whorl.

The ribbing is fine and strongly flexuous. The primary ribs incline forward on the umbilical wall and on the lower third of the flanks where they recurve and then pass into pairs of slightly weaker secondary ribs that incline forward strongly on the venter. Bifurcation on the inner whorls occurs on the lower third of the flanks, but during growth the points of furcation rise to the middle of the flanks. In a few places furcation occurs at or near the umbilical edge. Many pairs of secondary ribs are separated by single ribs that arise above the middle of the flanks. All ribbing is much reduced in strength on the venter, even where shelly material is preserved. Tubercles are not present, although some of the primary ribs on the body whorl are faintly swollen at the umbilical edge. Each whorl is marked by five or six weak constrictions that are most evident on the venter.
The suture line is imperfectly preserved. It is characterized by the first lateral lobe being much longer than the ventral lobe. Its general plan is similar to that of $L$. lecontei (Anderson) (1938, p. 183, text fig. 3, no. 5, pl. 47 , fig. 3), but its major lobes and saddles are more slender and less frilled, and its auxiliary lobes are much smaller.

The specimen shown on plate 19 , figures $9-11$, has been only slightly compressed. At a diameter of 40 $\mathrm{mm}$, its whorl height is $18.5 \mathrm{~mm}$, its whorl thickness is $13.5 \mathrm{~mm}$, and its umbilical width is $10 \mathrm{~mm}$. These dimensions are similar to those of the holotype.

$L$. deansi (Whiteaves) in general appearance is similar to Leconteites lecontei (Anderson) (see pl. 19, figs. 1-3) from the early Albian of California and Oregon, but may be distinguished by having stronger primary ribs, by lacking tubercles, and by developing a sharp umbilical rim at a much later growth stage.

Type: Plesiotypes USNM 130164, 130170.

Localities: USGS Mes. locs. 2201, 8872, 9967a, 9972. Fragmentary specimens possibly belonging to L. deansi (Whiteaves) were found at Mes. locs. 8873, 8880, 9967, 9973, 14484.

\section{Leconteites cf. L. deansi (Whiteaves)}

Plate 19, figures $15-27$

From the same beds as specimens assigned to $L$. deunsi (Whiteaves) and in part from the same localities (Mes. loc. 8872, 9972) have been obtained 25 specimens of Leconteites that differ from $L$. deansi by having much stronger primary ribs, a slightly wider umbilicus, a stouter whorl section, and rounder flanks (pl. 19, figs. 19-27). These features would ordinarily be sufficient to justify assigning them to a distinct species. Howerer, the presence at other localities (Mes. locs. 2201, 14484) of 4 specimens (pl. 19, figs. 16-18) that are intermediate in appearance suggest that the 25 stout, coarsely ribbed specimens are merely an extreme variana of $L$. deansi (Whiteaves). Their status cannot be settled definitely by the specimens on hand.

Figured specimens: USNM 130158, 130162, 130169, 130174. Localities: USGS Mes. loc. 2201, 8872, 8873, 8878, 9972, 14484.

\section{Genus LEMUROCERAS Spath, 1942}

Lemuroceras talkeetnanum Imlay, n. sp.

Plate 18, figures $\mathbf{3 4 - 4 1}$

?Lemuroceras cf. L. indicum Spath. McLearn, 1945, Geol. Survey Canada Paper 44-17 (2d ed.), pl. 5, fig. 4.

This species is represented by two specimens that retain some of the inner shelly layer. On this layer feather structures is well shown at one place (Arkell, in Arkell, Kummel and Wright, 1957, p. L92). The whorls are subquadrate in section and higher than wide 
and embrace about three-fifths of preceding whorl. The flanks are flattened, but become gently convex on the body chamber. The venter is nearly flat on the sutured part of the shell and gently rounded on the body chamber. The umbilicus is moderately narrow; the umbilical wall is low and steeply inclined and rounds evenly into the venter. The body chamber is represented by half a whorl and appears to be complete.

The ribbing on the septate part of the body whorl is prominent, widely spaced, and strongly flexuous. About half of the ribs arise on the umbilical wall, are most prominent at the umbilical edge, incline forward strongly low on the flanks, recurve near the middle of the flanks, and arch forward strongly on the upper part of the flanks and on the venter. The remaining ribs either arise freely near, or below, the middle of the flanks, or are indistinctly connected with the longer ribs at about the top of the lower third of the flanks. All ribs are equally strong on the venter, and all are slightly reduced in strength along the midventral line.

The ribbing on the body chamber fades out rapidly toward the aperture and becomes less strongly arched on the venter. Near the aperture only weak lines of growth are visible where the shell is preserved and the internal mold is quite smooth.

The body chamber has been crushed laterally and cannot be measured. At the beginning of the body chamber, the whorl height is $17 \mathrm{~mm}$, and the whorl thickness is $13 \mathrm{~mm}$.

The suture line is quite similar to that of L. aburense (Spath) (1933, p. 801, pl. 129, fig. 5) from India. The first lateral lobe is a little longer than the ventral lobe. The first lateral saddle is very wide. The other lobes and saddles are relatively much smaller. The auxiliaries descend slightly toward the umbilicus.

This species is remarkably similar to $L$. indicum (Spath) (1933, p. 801, pl. 128, figs. 4a, b, 5a, b) from India and Madagascar (Collignon, 1949, p. 68, 69, pl. 12, figs. 2, 2a, b, pl. 14, fig. 2). It is distinguished from that species mainly by being more involute and by its ribs arching forward more strongly on the venter. It appears, also, to have flatter flanks, but that may be a result of compression. The primary ribs are not nearly so prominent at the umbilical edge as in the holotype of L. indicum (Spath), or in the ammonite fragment figured by McLearn (1945, pl. 5, fig. 4), from the western interior of Canada, but the ribs are of nearly the same strength as on the paratype of $L$. indicum (Spath) (1933, pl. 128, fig. 5a).

Types: Holotype USNM 13015. Paratype USNM 130150. Locality: USGS Mes. loc. 24877.
Lemuroceras? sp. juv. cf. L. dubium Collignon

Plate 18, figs. 26-29

One small specimen has a subquadrate whorl section, flattened flanks and venter, a moderately wide umbilicus, and a low vertical umbilical wall that rounds evenly into the flanks.

The ribs are strongly flexuous on the flanks and arch forward moderately on the venter. Most ribs begin on the umbilical wall and remain single on the flanks. About one-third of the ribs bifurcate at, or below, the middle of the flanks, or are indistinctly connected with secondary ribs. A few secondary ribs arise freely on the flanks. The secondary ribs are as strong, or nearly as strong, as the primary ribs. All ribs are slightly reduced in strength along the midventral line. Six weak constrictions are present, but are conspicuous only on the venter.

At a diameter of $25 \mathrm{~mm}$, the whorl height is $10 \mathrm{~mm}$, the whorl thickness is $8 \mathrm{~mm}$, and the umbilical width is $7.5 \mathrm{~mm}$.

The suture line is not preserved.

This specimen is assigned to Lemuroceras rather than to Leconteites because of the characteristics of its ribbing, but it does have a vertical wall, a feature which is characteristic of Leconteites. Its appearance in lateral view is similar to that of $L$. dubium Collignon from Madagascar $(1949$, p. 74, pl. 15, figs. 2, 2a, b), but it has fewer secondary ribs and more primary ribs per whorl, is more compressed, and has a vertical umbilical wall.

Figured specimen: USNM 130157.

Locality: USGS Mes. loc. 14484.

\section{Subgenus SUBARCTHOPLITES Casey, 1954, revised Imlay}

Subarcthoplites Casey $(1954$, p. 111) based on Lemuroceras belli McLearn (1945, pl. 3, figs. 17, 18) from the western interior of Canada was considered by its author to be more similar to the boreal genus Arcthoplites than to Lemuroceras from India and Madagascar. The discovery of adult specimens of Lemuroceras belli McLearn in northern Alaska shows, however, that it differs from Arcthoplites by lower points of rib branching, by the presence of constrictions, and by its ribs fading on the body chamber instead of becoming coarser. In these respects it is identical with typical species of Lemuroceras from India and Madagascar. Lemuroceras belli McLearn differs from the typical species only by having rounder flanks, less flexuous ribbing, and a less abrupt change in the direction of ribbing on the lower part of the flanks. These differences are slight and are not considered worthy of more than subgeneric rank. 


\section{Lemuroceras (Subarcthoplites) aff. L. belli McLearn}

Plate 18, figures $23,30-33$

Two immature specimens of Lemuroceras from the Chitima Valley differ from $L$. be $77 i$ McLearn (1945, pl. 3 , figs. 17,$18 ; 1948$ ) by being more compressed and by having weaker ribs that bifurcate less commonly and are more widely spaced on the venter.

The small specimens from the Chitina Valley each have about one-third of a whorl of body chamber. On the septate part of the shell the primary ribs incline forward strongly on the umbilical wall and on the lower third of the flank where most of them either bifurcate or are indistinctly connected with a secondary rib. All ribs curve backward near the middle of the flanks and then arch forward gently on the venter. On the body chamber, furcation becomes less common and secondary ribs become fewer. All ribs continue across the venter with only slight reduction in strength as compared with the ribs on the flanks.

The suture line has a very wide first lateral saddle and a wide trifid first lateral lobe that is only slightly longer than the ventral lobe. The auxiliaries are curved slightly adorally. The pattern of the suture is similar to that of L. aburense (Spath) (1933, pl. 129, fig. 5) from India.

Figured specimen: USNM 130136.

Locality: USGS Mes. loc. 9492.

\section{Arcthoplites? sp.}

Plate 18, figures 22, 24, 25

Two fragments bear high, thin, widely spaced ribs similar to those on the outer whorl of Arcthoplites jachromensis (Nikitin) (1888, p. 57, pl. 4, fig. 1) from the lower or middle Albian of Russia. On the venter of the internal mold the ribs arch forward and become a little broader and lower. In places where the shell is preserved the ribs are much thicker than on the internal mold. As the lower parts of the flanks are not preserved, the fragments could be assigned as readily to Tetrahoplites or Pseudosonneratia as to Arcthoplites.

Figured specimen: USNM 130137.

Locality: USGS Mes. loc. 9492.

\section{REFERENCES}

Anderson, F. M., 1938, Lower Cretaceous deposits in California and Oregon: Geol. Soc. America Spec. Paper 16 339 p., 85 pls., 6 figs.

1902, Cretaceous deposits of the Pacific Coast: California Acad. Sci. Proc., 3d ser., v. 2, 126 p., illus.

Anthula, D. J.. 1899, Über die Kreidefossilien des Kaukasus: Beitr. Paläontologie Oesterr.-Ungarns u. des Orients, v. 12 , p. 55-102, pls. $2-7$.
Arkell, W. J. and Playford, P. E., 1954, The Bajocian ammonites of western Australia: Royal Soc. London Philos. Trans., ser. B. Biological Sciences, no. 651, v. 237, p. 547605 , pls. $27-40$.

- in Arkell, W. J., Kummel, Bernhard, and Wright, C. W., 19.57, Mesozoic Ammonoidea: Treatise on Invertebrate Palentology, part L, Mollusca 4, 490 p.. illus.

Breistroffer. Maurice, 1947, Zur las zones d'Ammonites dans l'Albian de France et d'Angleterre: Grenoble Univ., Lab. geologie. Travaux, v. 26. p. 1-88.

Brinkmann, Roland, 1937, Biostratigraphie des Leymeriellenstammes nebst Bemerkungen zür Paläogeographie des Nordwestdeutschen Alb: Hamburg Min. geol. Staatsinst. Mitt., no. 16, p. 1-18, figs. 1-12.

Cases, Raymond, 1954, New Genera and subgenera of Lower Cretaceous ammonites: Washington Acad. Sci. Jour., v. 44, no. 4 , p. $106-115,1 \mathrm{pl}$.

- 1957. The Cretaceous ammonite genus Leymeriella, with a systematic account of its British occurrences: Palaeontology, v. 1, pt. 1, p. 29-59, pls. $7-10,6$ text figs.

Chaput, M. E., 1920, Les Desmoceratides du Paleocretace. Revision du genre Desmoceras in Kilian, Wilfred, and others, Contributions a l'etude des céphalopodes paléocrétacés du Sud-Est de la France: Mém. Carte géol. det. France, p. $167-180,1 \mathrm{pl}$.

Collingnon, Maurice, 1937. Les ammonites pyriteuses de rAptien D'Antanatana-mirafy: Paléont. de Madagascar, 22. Annales de paléontologie, p. 107-132. pls. 1-3.

1949. Recherches sur les faunes Albiennes de Madagascar I-L'Albien d'ambarimaninga (Madagascar); Annales geol. Serv. des Mines de Madagascar. part 16, 128 p., 22 pls., 29 text figs.

Fallot, Paul. 1920a, La faune des marnes aptiennes et albiennes de la region d'Andraitz, Majorque: Trab. Mus. Nac. de (ienc. Nat. ser. geol., no. 26 (Madrid), p. 1-68, pls. 1-3.

1920b, Remarques sur le genre Silesites in Kilian, Wilfred, and others, Contributions a retude des céphalopodes paléoccétacés du Sud-Est de la France: Mém. Carte geol. det. France, p. 207-226, 7 text figs.

Gabb. W. M., 1864. Description of the Cretaceous fossils: California Geol. Survey, Paleontology, v. 1, p. 56-236, pls. 1-32. 1869, Cretaceous and Tertiary fossils: California Geol. Survey, Paleontology, v. 2, 299 p., pls. 1-36.

Hall, E. B., and Ambrose, A. W., 1916. Description of new species from the Cretaceous and Tertiary of the Telsa, Pleasanton, San Jose and Mount Hamilton quadrangles, California : Nautilus, v. 30, p. 68-71.

Henderson. W. R. S.. 1954, Cretaceous and some Triassic beds of northeastern British Columbia, Canada: Am. Assoc. Petroleum Geologists Bull., v. 38, no. 11, p. 2269-2289, 6 figs.

Hyatt, Alpheus, 1900, ('ephalopoda in Zittel, K. A., Textbook of Palaeontology: 1st English ed. transl. Eastman, C. R., p. 502-592. figs. 1049-1235.

Imlay, R. W., 1959. New genera of Early Cretaceous (Albian) ammonites from Alaska: Jour. Paleontology, v. 33, no. 1, p. 179-185, pls. 29, 30, 2 tables.

1960, Characteristic Early Cretaceous megafossils from northern Alaska: U.S. Geol. Survey Prof. Paper 335 (in press).

Inlay, R. W., and Reeside, J. B., Jr., 1954, Correlation of the Cretaceous formations of Greenland and Alaska: Geol. Soc. America Bull., v. 65. p. 223-246, 1 correlation table. 
Jacob, Charles, 1908, Étude sur quelques ammonites du Crétacé Moyen: Soc. geol. France, Paleont. Mém. no. 38, for 1907, 63 p., 9 pls.

Koenen, A. von, 1902, Die Ammoniten des Norddeutschen Neocom (Valanginien; Hauterivien. Barremien und Aptien); Preuss. geol. Landesanstalt Abh., N. F., no. 34, 451 p., 55 pls.

Kilian, Wilfred, 1907-1913, Unterkreide (Palaeocretacicum) in Frech, F., Lethaea Geognostica, II, Mesozoicum, v. 3 (Kreide), 398 p., pls. 1-14.

Martin, G. C., 1926. The Mesozoic Stratigraphy of Alaska, U.S. Geol. Survey Bull. 776, 493 p., 13 figs.

Matsumoto, Tatsuro, 1955, Family Kossmaticeratidae from Hokkaido and Saghalien: Japanese Jour. Geology and Geography, v. 26, nos. 1, 2, p. 115-164, pls. 8-10.

- 1959, Cretaceous ammonites from the upper Chitina Valley, Alaska. Mem. Fac. Sci. Kyushu Univ., ser. D, and Geology, v. 8, no. 3, p. $49-90$, pls. $12-29,16$ text figs.

McLearn, F. H., 1931, The Gastroplites and other Lower Cretaceous faunas of the northern Great Plains: Royal Soc. Canada Proc. and Trans. 3d ser., v. 25, sec. 4, p. 1-8, pls. 1, 2, 1 text fig.

1945 , Revision of the Lower Cretaceous of the western interior of Canada: Canada Geol. Survey Paper 44-17 (2d ed.), 14 p., 2 tables, 12 pls.

- 1948, New Lower Cretaceous species from Alberta and northeastern British Columbia: Appendix to Canada Geol. Survey Paper 44-17, 2 p.

McLearn, F. H., and Kindle, E. D., 1950, Geology of northeastern British Columbia: Canada Geol. Survey Men. 259, 236 p., 8 pls., 16 text figs., 1 map, 6 tables.

Moffit, F. H., 1938, Geology of the Chitina Valley and adjacent area Alaska: U.S. Geol. Survey Bull. 894, 137 p., 16 pls., 1 map.

Moffit, F. H., and Overbeck, R. M., 1918, The Upper Chitina Valley, Alaska, with A description of the igneous rocks: U.S. Geol. Survey Bull. 675, 82 p., 13 pls., 2 figs.

Murphy, M. A., 1956, Lower Cretaceous stratigraphic units of northern California: Am. Assoc. Petroleum Geologists Bull., v. 40, p. $2098-2119,6$ figs.

Nikitin, S. N., 1888, Les vestiges de la période crétacée dans la Russie centrale: Com. Geol. St. Petersbourg. Mem., v. 5, no. 2, p. 166-205, pls. 1-5, map.

Orbigny. Aleide d', 1840-1842, Paléontologie de Francaise: Terrains Cretaces, v. 1, 662 p., 148 pls.

Parona, C. F., and Bonarelli, Guido, 1897, Fossili Albiani d'Escragnolles del Nizzardo e della Liguria occidentale: Palaeontogr. Italica, v. 2, p. 53-112, pls. 10-14.

Pervinquiere. L., 1907, Études de paléontologie tunisienne. I Céphalopodes des terrains secondaires. (Carte geol. Tunisie), Systeme Crétacique, p. 43-428, pls. 1-27.

Pictet, F. J., and Roux, W., 1817-53, Description des mollusques fossiles qui se trouvent dans les gres verts des environs de
Genève: Soc. phys. et hist. nat. Genève, v. 1, pt. 4, 286 p., pls. 26-43.

Sinzow, I. T., 1909, Beiträge zur Kenntniss des südrussischen Aptien und Albien: Verh. russ. k. Min. Gesell. St. Petersburg, ser. 2 , v. 47 , p. $1-48$, pls. $1-4$.

Spath, L. F., 1923-1943, A monograph of the Ammonoidea of the Gault: Palaeontogr. Soc., 2 v., 787 p., 72 pls., 248 text figs., 4 tables.

1927-33, Revision of the Jurassic cephalopoda fauna of Kachh (Cutch): Palaeontologia Indica new ser. v. 9, 6 pts.. 945 p., 130 pls.

1930, The fossil fauna of the Semana Range and some neighboring areas: part $\mathrm{V}$. The Lower Cretaceous ammonoidea; with notes on Albian cephalopoda from Hazara : Palaeontologia Indica, new ser., v. 15, p. 51-66, pls. 8, 9.

Stanton, T. W., 1895, Contributions to the Cretaceous Paleontology of the Pacific Coast, The fauna of the Knoxville beds: U.S. Geol. Survey Bull. 133, 132 p., 20 pls. [1896].

Stelck, C. R., Wall, J. H., Bahan, W. G., and Martin, L. J., 1956, Middle Albian foraminifera from Athabasca and Peace River Drainage areas of western Canada: Research Council of Alberta Rept. 75, 60 p., 5 pls., 2 figs.

Uhlig, Victor, 1883, Die Cephalopodenfauna der Wernsdorfer Schichten: K. Akad. Wiss., Math.-naturh. Kl., Denks, v. 46 , p. 1-166 (128-290), 32 pls.

Warren, P. S., 1947, Cretaceous fossil horizons in the Mackenzie River valley: Jour. Paleontology, v. 21, no. 2, p. 118-123, pls. $29,30$.

Whiteaves, J. F.. 1876. On some invertebrates from the coalbearing rocks of the Queen Charlotte Islands: Canada Geol. Survey, Mesozoic Fossils, v. 1, p. 1-92, pls. 1-10.

1889, On some Cretaceous fossils from British Columbia, the northwest territory and Manitoba: Canada Geol. Survey, Contr. to Canadian Paleontology, v. 1, p. 151-196, pls. 20-24.

1893a, Notes on the ammonites of the Cretaceous rocks of the district of Athabasca, with descriptions of four new species: Royal Soc. Canada Proc. and Trans., 1 ser., v. 10, sec. 4 , p. 111-121, pls. 8-10.

- 1893b, Descriptions of two new species of ammonites from the Cretaceous rocks of the Queen Charlotte Islands : Canadian Record Science, v. 5, p. 441-446, pl. 7 .

Whitehouse, F. W., 1928, Additions to the Cretaceous ammonite fauna of eastern Australia, part 2 (Desmoceratidae) : Mem. Queensland Museum, v. 9, pt. 2, p. 200-206, pls. 25, 26.

Wollemann, A., 1907, Die Fauna des mitteren Gaults von Algermissen: Jahrb. Preuss. Geol. Landesanstalt u. Bergakademie für 1903, v. 24, p. 22-42, pls. 4, 5.

Wright, C. W., in Arkell, W. J., Kunmel, Beruhard, and Wright, C. W., 1957, Mesozoic Ammonoidea: Treatise on Invertebrate Paleontology, part L, Mollusca 4, 490, p., illus. 


\section{INDEX}

[Italic numbers indicate descriptions]

A

Page

hurense, Lemuroceras

affine, Beudanticeras. glabrum, Desmoceras.

agassizianum, Kossmatella. 100 alaskana, Puzosia_.............. 91, 98,104, pl. 16 alaskanum, Callizoniceras................. 101 Callizoniceras (Wollemanniceras) _...... 91,98, 101

pl. 12

Albian ammonites, geographic distribution ... 98 Albian faunules. . ........................ 93 aldersoni, Calliphylloceras Ammonite faunules and correlations ....... 89-93 breweri haydeni....... 106 .1 nagaudryceras _... aurarium_... _. _. _.. $89,91,98,99$, pl. 11 sp. indet _............... 91,98 anglicus, Inoceramus................ 91

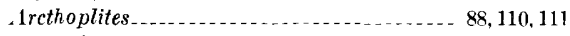
jachromensis _... _... sp_..................... 91,98,111, p1. 18 (Astiera) deansi, Olcostephanus _.......... 109 Astieridiscus_.......................... 102 I ucella........

crassicollis

pallasi

Aucellina

Aucellina $\mathrm{sp}$

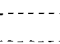

\section{89}

$89,91,94$ arium, $89,91,98,99, \mathrm{pl}, 11$ Lytoceras (Kossmatella) ............... 99 $\mathrm{B}$

baylei, Cleoniceras 108

Bear Creek belli, Lemuroceras _. . . . . . 92, 97, 110,111, pl. 18 Lemuroceras (Subarcthoplites)_ 91,92,98,111, pl. 18

Beaudanticeras............ 88, 93, 94, 105, 106 affine breweri glabrum _............... 92, 93, 98, 105, pl. 16 hulenense..................... 106

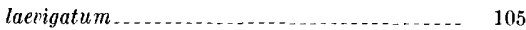
sutherlandi

(Grantziceras)

88 multiconstrictum _............. 92,98, 105, pl. 14 Beudanticeratinae...................... 88 Sicurvatoides, Cleoniceras

bifurcata, Kennicottia ................... 91

Billy Creek

Biologic analysis $\ldots$

breweri, Ammonites. Beudanticeras ........................ 105 Brewericeras _.......... 91, 92, 94, 98, 105, pl. 17 Brewericeras ............... 88,93,94,97, 10 5 breweri................ 91, 92, 94, 98, 105, pl. 17 faunule...................... 91,92,97 haydeni................................. 91, 105 hulenense_._._._._. 89, 91, 94, 98, 106, pl. 17 zone........ $91,92,94,98$

bullatus, Parasilesites..........91, 98, 106, pl, 18
C Page

californicum, Hypophylloceras._._... 91, 98, pl. 11 Calliphylloceras......... 88.99 aldersoni_._. nizinanum............ 91, 98, 99, pl. 11 Calliphylloceratinue.. .................. 88 Callizoniceras _... $88,93,94,97,101,102,103$ alaskanum ................... 101

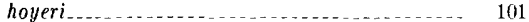
(Wollemanniceras) alaskanum fohlinense _._. _._........ 91, 98, 101, pl. 12 keilhacki

Canyon Creek cap psi, Kossmatella Cephalopoda

chirichensis, Puzosia

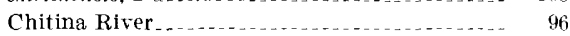

Chitina Valley _. _.......

chitinanum, Phyllopachyceras_... _... . 91,9\%,98, pl. 11

Chokosna River......... 96

Clansayes beds.

Clearwater formation ................... 92

cleon, Cleoniceras......................... 108

Cleoniceras _ . . . . _ _ _ _ _ _ _ $88,92,94,108$ baylei_........ 108 bicurvatoides................. 108 cleon leightonense $\ldots$ modestum ..................... 109 overbecki_....._._._._._._._. 91, 98, 108, pl. 19 Cleoniceratinae ............. 88 comancheanus, Inoceramus. Copper River basin .................... 88 Correlations and ammonite faunules ... . . . . _ _ 89-93

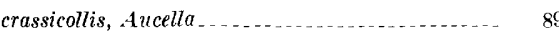
crassicostatus, Leconteites....... 91

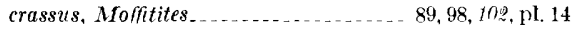

\section{T)}

deansi, Leconteites__..._. 91, 94, 98, 109, pl. 19 Olcostephanus (Astiera) _... _. . . 109 Desmoceras ... _. 88,94,100. 102, 106 affine glabrum $\ldots$ merriami............. 106 noyi sp. juv _..._. Desmoceratidae _............. 88, 93 Desmoceratinae _. . . Douvilleiceras $\ldots$ mammillatum zone dubium, Lemuroceras _... _... . . 98, 110, pl. 18 Flume Creek Flume Creek $\ldots \ldots$
Fohlin Creek fohlinense, Callizoniceras (Wollemanniceras) 91. 98, 171, pl. 12

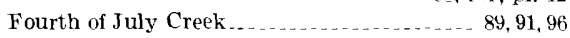
Freboldiceras singulare $\ldots \ldots \ldots \ldots \ldots 92,93,94,97,98,1 \cap 2$, pl. 14 faunule ... . . . . . . . . 92-93

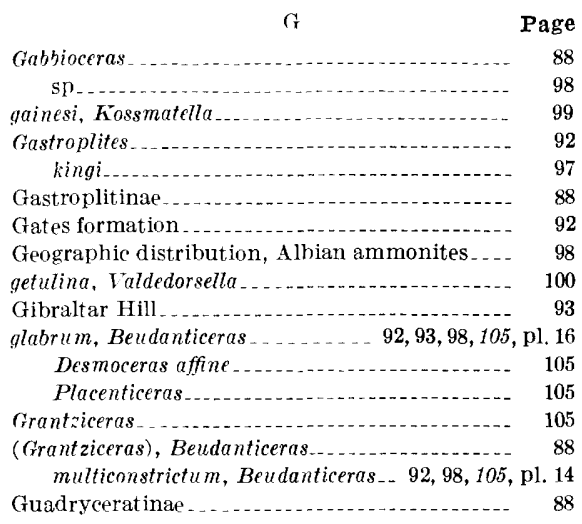
H

Harmon shale member, Peace River formation.. $\quad 92$ haydeni, .1mmonites. .......................... 106 Brewericeras.......... 91, 106 Hoplites dentatus zone . . . . . . . Hoplitidae $\ldots 8,94$

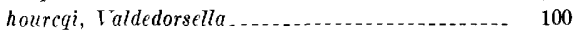
hoyeri, Callizoniceras hulenense, Beudanticeras _................ 106 Brevericeras _........ $89,91,94,98,106, \mathrm{pl}, 17$ Hulenites _. . . . . . . 88, 92, 93, 97, 104, 107 reesidei__............... 91,98, 104,107, pl. 18 I1y poph ylloceras _. . . . . . . . californicum onoense.

indic $u m$, Lemuroceras... . . . . . . . . 92,93, 109 indigenes, Melchiorites Inocera mus . _.......... 88,91 anglicus_......................... 91 comancheanus irenense, Lemuroceras irregularis, Parasilesites.............. 91, 98, 107, pl. 18 J

jachromensis, Arcthoplites.

$\mathrm{K}$

kellhacki, Callizoniceras (Wollemanniceras) _.... 101 Kennicott formation .................. 98 Kennicott Glacier . . . . Kenuicott River Kennicottia bifurcata _.. _. _ _... _. $91,98,193,104$, pl. 15 rugosa _............... $91,98,103, \mathrm{pl} .15$ kingi, Gastroplites Kossmatella agassizianum . . . . сарpsi _. _ _ _ _ gainesi_._. (Kossmatella) aurarium, Lytoceras.-.-.-.- 99 Kossmatellinae

Kossmaticeratidae...................... 88, 94 
Page

Kuskulana Pass

Kuskulana River

$\mathrm{I}$

laeve, Ptychoceras _... 91, 98, 100, pl. 12 laevigat um, Beudanticeras....... Lakina River- ... lecontei, Leconteites.

Leconteites $\quad 88,89,91,93,94,97,108,110$ crassicostatus _............ 91 deansi faunule

lecontei 109 zone $\ldots 9, \ldots 1,92,94$ modestus__- 89, 91, 94, 98, 109 , pl. 19 faunule _... sp leightonense, Cleoniceras......................... 108 Lemuroceras_._. aburense... . . . belli_............ 92, 97, 110, 111, pl. 18 $92,97,110,111, \mathrm{pl} .18$ zone indicum .................. 92, 93, 109 irenense $\quad 92,93,103$ talkeetnanum............... 92, 98, 109, pl. 18 (Subarcthoplites) _..._._._._._. 88, 92, 93, 94, 97 Loon River formation. . .......... 99 Lunatodorsella.

Lytoceras (Kossmatella) aurarium

M

McCarthy Creek Matanuska formation ................ 96, 98

Melchiorites. indigenes................................ 104 merriami, Desmoceras............. 106 modestum, Cleoniceras . . . . . . . . . . . ........ 109 modestus, Leconteites . . . _... 89, 91, 94, 98, 109, pl. 19 , Moffitites _. $88,91,93,101$ crassus ........... 89, 98, 102, pl. 14 robustus................... 91, 94, 98, 102, pl. 13 faunule . . . . . . . . . $11-92$ Moosebar formation..................... 92 multiconstrictum, Beudanticeras (Grantziceras) _.- 92,

$98,105, \mathrm{pl} .14$

Nelchima limestone.

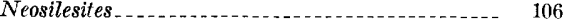

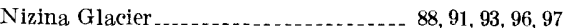

Page

nizinanum, Calliphylloceras_.......... 91, 98,99, pl. 11 Notikewin member, Peace River formation.... 92

\section{O}

Olcostephanus (Astiera) deansi_............... 109 onoense, IIy pophylloceras overbecki, Cleomiceras $\mathrm{P}$

pallasi, Aucella

Parasilesites $88,92,94,106$ bullatus _ $91,98,106, \mathrm{pl} .18$ irregularis.................. 91, 98, 10\%, pl. 18 Peace River formation, Harmon shale member . $\quad 92$

Notikewin member

perrinsmithi, ruzosigella........ 89,98

Phylloceratidae. ...

Phylloceratinae.

Phyllopachyceras _._. chitinan um _..._._._._._._._. 91,97,98, pl.11 shastalense_..................... 91, 98 theresae

Placenticeras glabrum ..................... 105 Pseudohaploceras. Pseudoley meriella............................. 88

Pseudosonneratia........................... 111

Ptychoceras. laeve

Ptychoceratidae............................. 88, 94

Puzosia alaskana chirichensis_. . . . quensledti subquadrata 103 sp. . sp indet.

puzosiaformis, Silesites

Puzosigella _....______._._ 88, 89, 91, 93, 94, 97, 108 faunule perrinsmithi. . . .

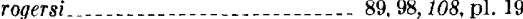
taffi_.._._. spp..... 89,94 Puzosinae

Queen Charlotte Islands robustus, Moffitites.............. 91, 94, 98, 102, p1. 13 rogersi, Puzosigella _..._._._._._. 89, 98, 108, pl. 19 Sonnratia 108 rugosa, Kennicottia . . . .
S

Page

shastalense, Phyllopachyceras 91,98 Silesites_._._._._._. 89, 106, 107 puzosiaformis vulpes._._. Silesitidae singulare, Freboldiceras. ..... 92, 93, 94, 97, 98, 102, pl. 14 Slatka Creek ... 88

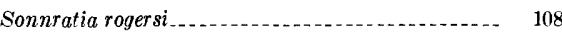
Stratigraphic summary Subarcthoplites............................. 92, 110 (Subarcthoplifes) belli, Lemuroceras.......... 91, 92,98 Lemuroceras _._. subquadrata, Puzosia Summary of results ......... sutherlandi, Beudanticeras .................. 105 Systematic descriptions............. $97-111$

taff, Puzosigella Talkeetna Mountains _..._._. talkeetnanum, Lemuroceras._._._._. 92,98, 109, pl. 18
Tetragonites._... timotheanus.......... $91,98,100$, pl. 12 $\mathrm{sp}$

pp. 98 Tetragonitidae Tetragonitinae - . . .

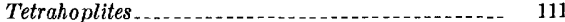
theresae, Phyllopachyceras...._-_._._._._. 98 timotheanus, Tetragonites....... $91,98,100$, pl. 12 Trail Creek $88,92,94,100,102,103$ akuschaensis 100 akuschaensis._.
getulina. hourcqi $i_{-\ldots} \ldots$ whiteavesi............. 91, 98, 100, pl. 11 voyi, Desmoceras. vulpes, Silesites . . .

W

whiteavesi, Valdedorsella_._._._._.. 91, 98, 100, pl. 11 Wollemanniceras................................. 101

(Wollemanniceras) alaskanum, Callizoniceras... 91, 98,101, pl. 12

Callizoniceras fohlinense, Callizoniceras. . _....... 91,98, 101, pl. 12 keilhacki, Callizoniceras................ 101

Y 


\section{PLATES 11-19}




\section{PLATE 11}

[Figures natural size unless otherwise indicated]

Figures 1-5. Phyllopachyceras chitinanum Imlay, n. sp. (p. 97).

Holotype USNM 130142, from USGS Mes. loc. 9492. Suture line drawn from adapical end of body chamber.

6-12. Calliphylloceras nizinanum Imlay, n. sp. (p. 99).

All specimens from USGS Mes. loc. 9492.

6, 10, 11. Paratype USNM 130139a.

7, 8. Holotype USNM 130138

9. Paratype USNM 130139b.

12. Paratype USNM 130139c.

13-17. Calliphylloceras cf. C. aldersoni (Anderson) (p. 99).

All specimens from USGS Mes. loc. 9972.

13. Specimen USNM 130161a showing traces of finely ribbed shell.

14. Specimen USNM $130161 \mathrm{~b}$.

15-17. Ventral, cross section, and lateral views of specimen USNM $130161 \mathrm{c}$

18, 19, 24. Anaqaudryceras aurarium (Anderson) (p. 99).

Both specimens from USGS Mes. loc. 14485.

18, 19. Immature septate specimen, USNM 130154a.

24. Adult specimen USN M 130154 b showing fine striations on the shell and deep constrictions on the mold. Body

chamber represented by three-fifths of a whorl.

20-23, 25-28. Valdedorsella? whiteavesi Imlay, n. sp. (p. 100).

Both specimens from USGS Mes. loc. 9492.

20-23, 25. Holotype, USNM 130145. Suture line drawn at diameter of $11.5 \mathrm{~mm}$. Note figures 21 and 22 are identical views at different magnifications.

26-28. Paratype USNM 130146.

29. Hypophylloceras cf. H. californicum (Anderson) (p. 98)

Specimen USNM 130132, from USGS Mes. loc. 9492. 

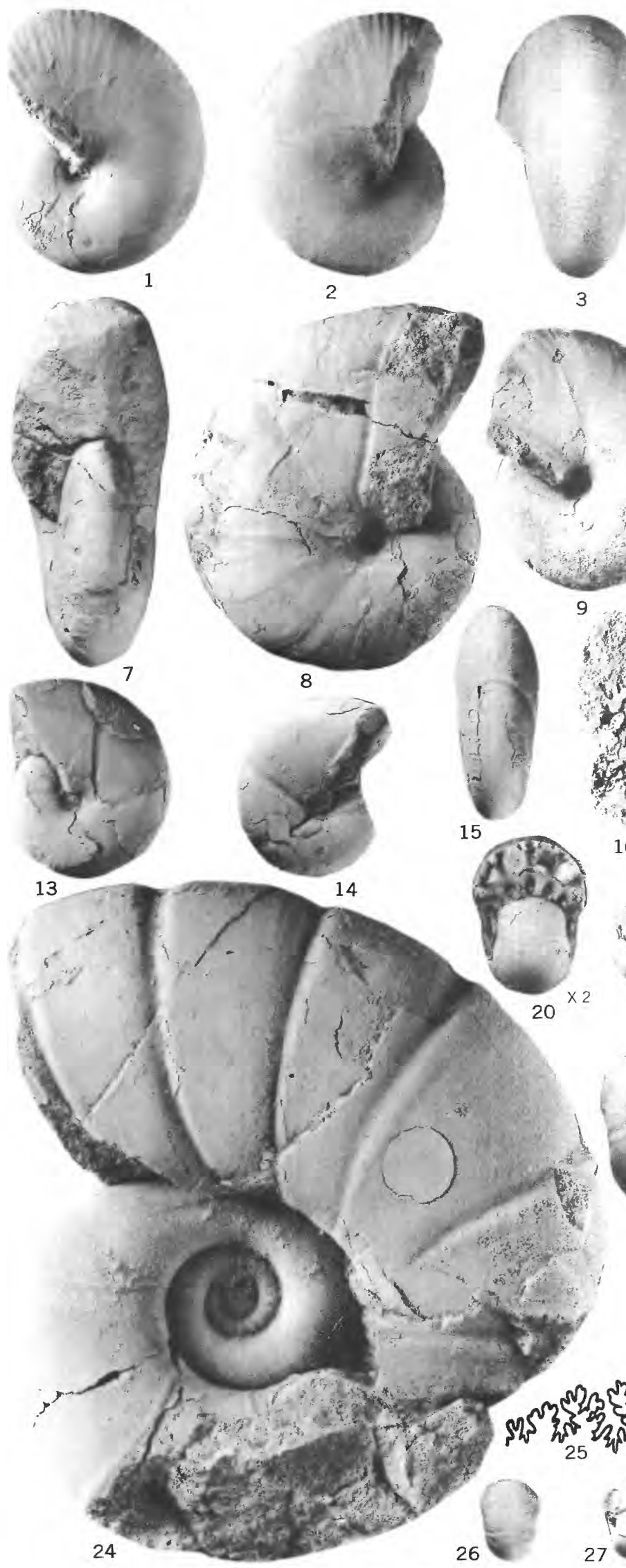

PHYLLOPACHYCERAS, CALLIPHYLLOCERAS, ANAGAUDRYCERAS, VALDEDORSELLA?, AND HYPOFHYLLOCERAS
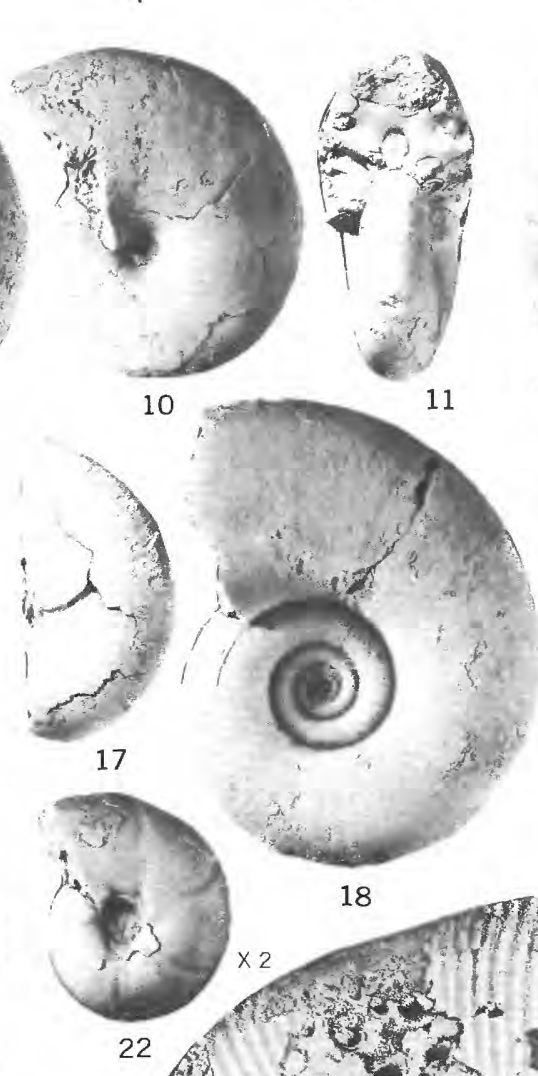

21
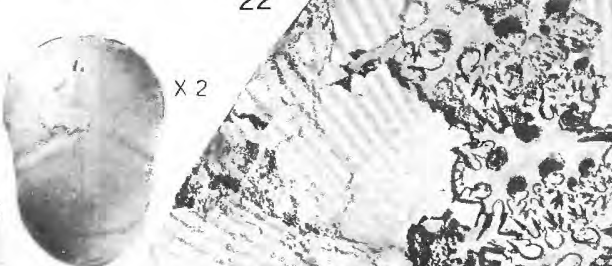

23
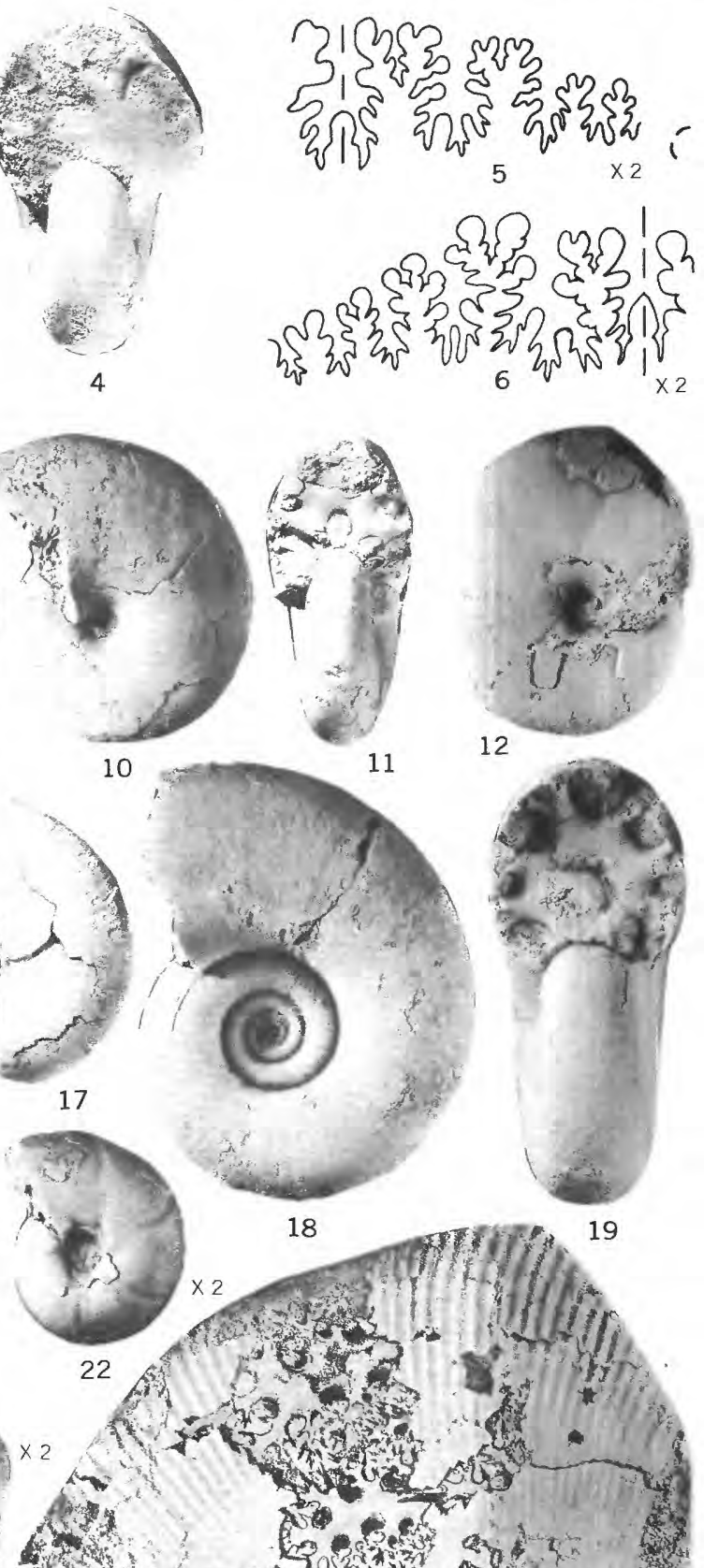

eson a

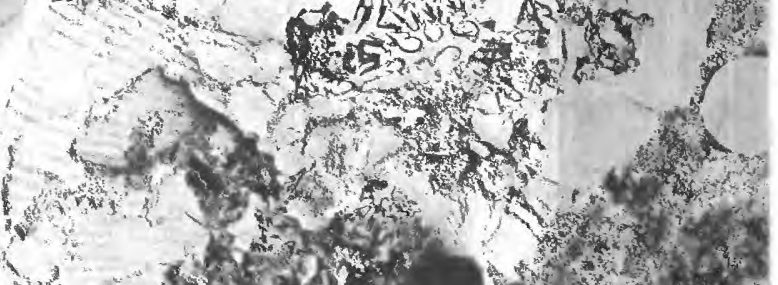

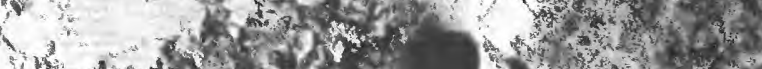
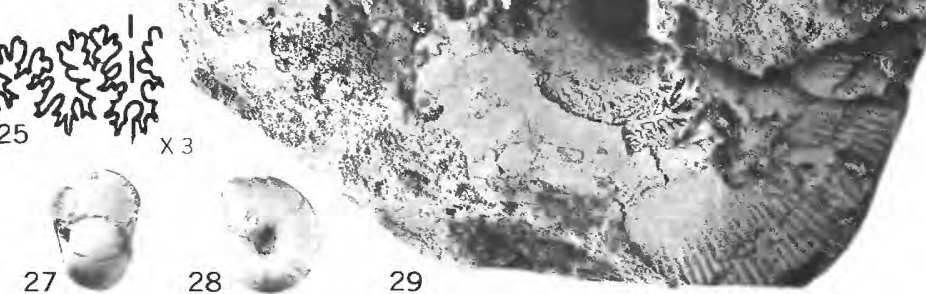


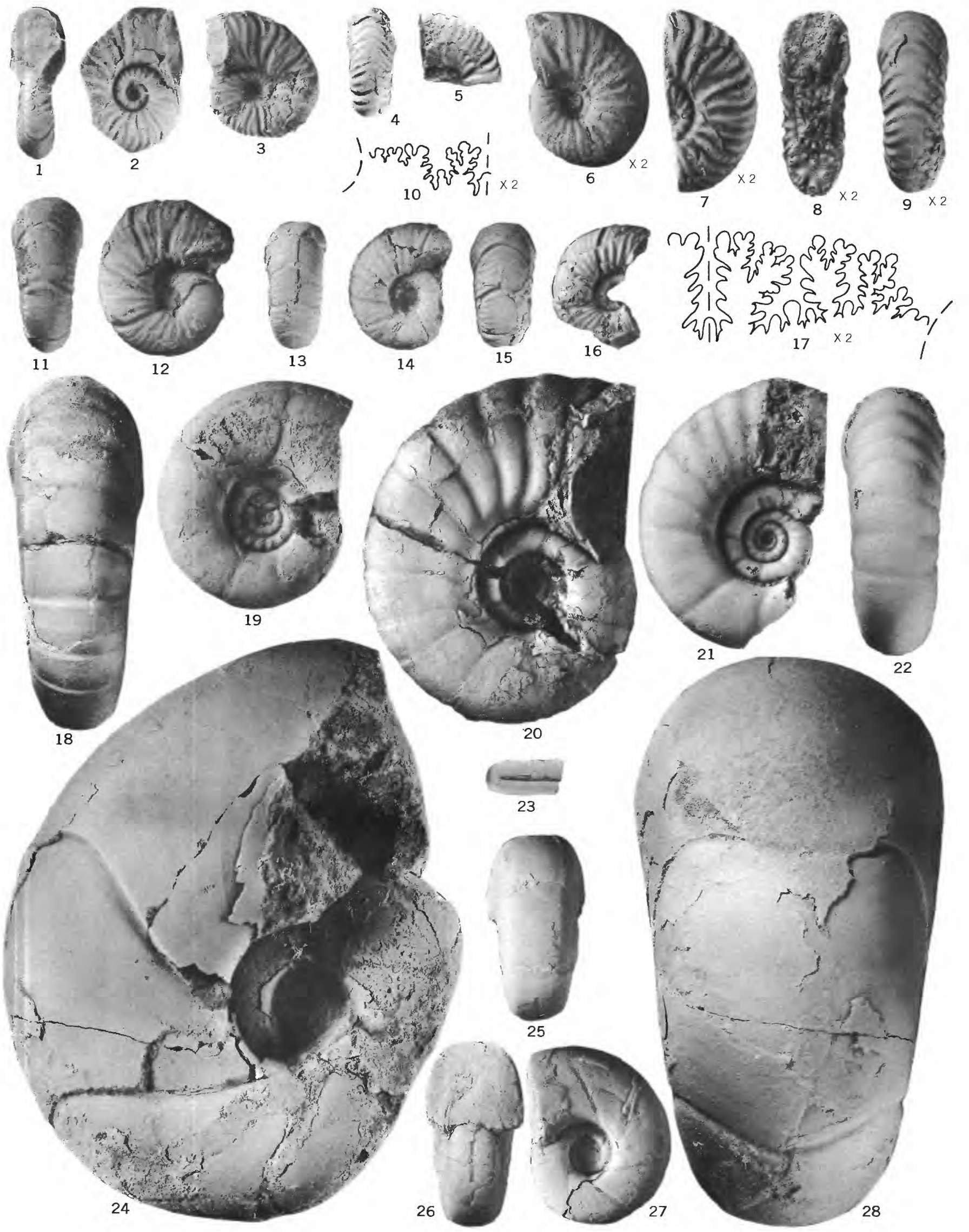

CALLIZONICERAS, KOSSMATELLA, PTYCHOCERAS, AND TETRAGONITES 


\section{PLATE 12}

[Figures natural size unless otherwise indicated]

Figures 1-10. Callizoniceras (Wollemanniceras) fohlinense Imlay, n. sp. (p. 101).

All specimens from USGS Mes. loc. 14484.

1, 2, 10. Holotype USNM 130155.

3. Paratype LSNM 130156a.

4, 5. Paratype USNM $130156 \mathrm{~b}$.

6. Paratype USNM 130156c. Weaker ribbed than the holotype.

7-9. Paratype USNM 130156d. Stronger ribbed than the holotype.

11-16. Callizoniceras (Wollemanniceras) alaskanum Imlay, n. sp. (p. 101).

Both paratypes from USGS Mes. loc. 8873 .

11, 12. Holotype USNM 130165, from USGS Mes. loc. 9976.

13, 14. Paratype USNM 130166a.

15, 16. Paratype USNM 130166b.

17-22. Kossmatella cappsi Imlay, n. sp. (p. 99).

Both paratypes from USGS Mes. loc. 9492.

17, 19. Paratype USNM 130140a.

21, 22. Paratype USNM 130140b.

18, 20. Holotype USNM 130160, from USGS Mes. loc. 14514.

23. Ptychoceras cf. P. laeve (Gabb) (p. 100).

Specimen USNM 130163, from USGS Mes. loc. 9972.

24-28. Tetragonites aff. T. timotheanus (Pictel) (p. 100).

Both specimens from USGS Mes. loc. 9492.

24, 28. Adult showing three-fifths of a whorl of body chamber, USNM 130131a. 25-27. Immature specimen USNM 130131b. 


\section{PLATE 13}

[Figures natural size unless otherwise indicated]

Frgures 1-13. Moffitites robustus Imlay. (p. 102).

1-3, 5. Septate paratype USNM 129875a, from USGS Mes. loc. 9972, is slenderer than most specimens of the species.

4, 9. Small septate paratype USNM 129876a, from USGS Mes. loc. 14485.

6-8. Normally stout septate paratype USNM 129875b, from USGS Mes. loc. 9972 . Note tendency of ribs to become threadlike on the venter.

10, 13. Holotype USNM 129874, from USGS Mes. loc. 2191. About three-fifths of a whorl belongs to the body chamber.

11, 12. Lateral views of paratype USNM 129876b, from USGS Mes. loc. 14485. Shows characteristic ribbing on inner whorls. 
GEOLOGICAL SURVEY

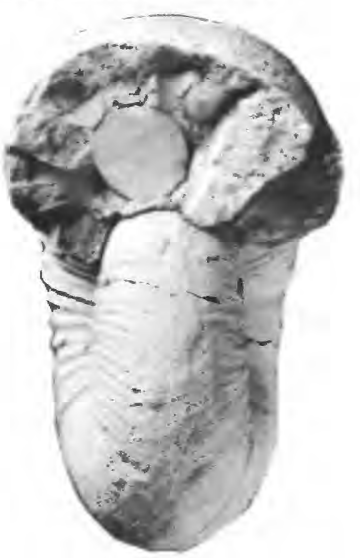

1

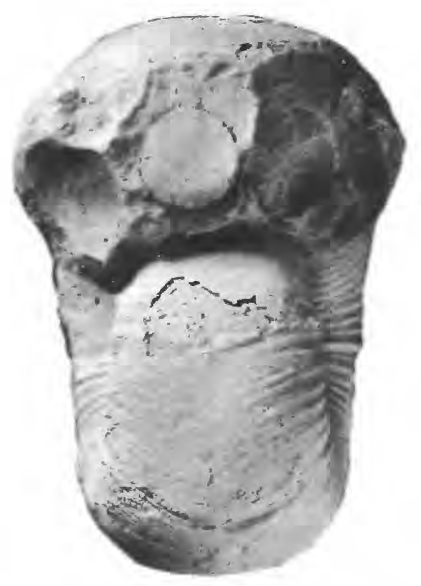

6

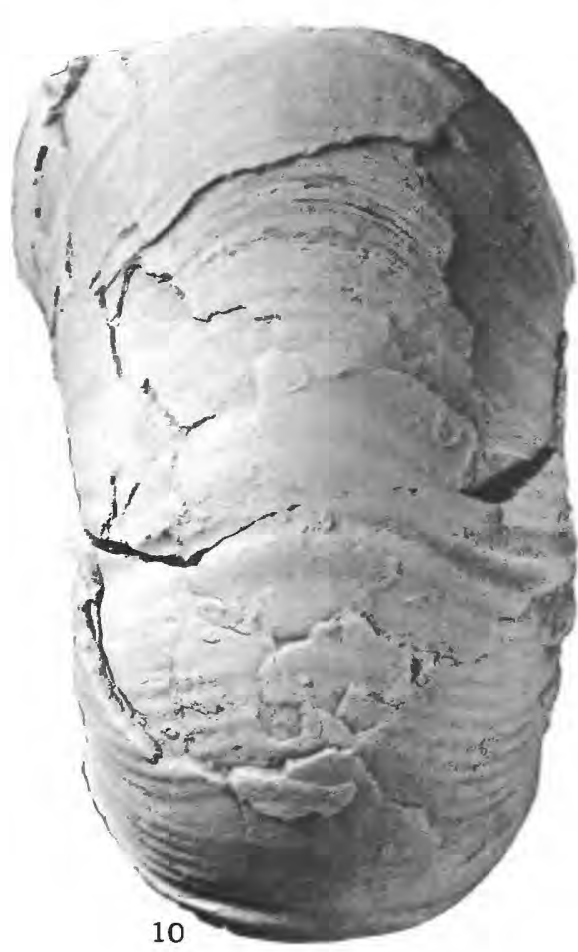

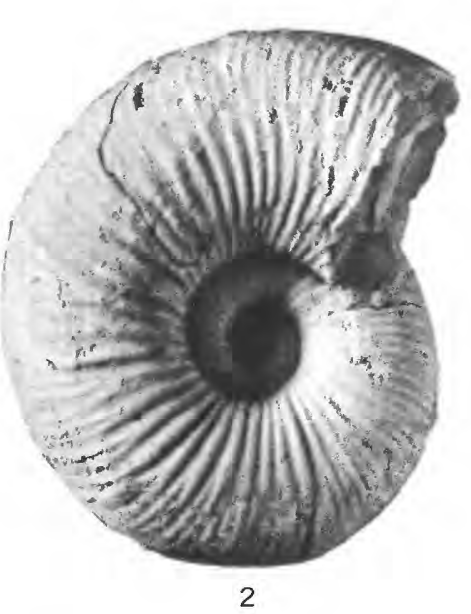
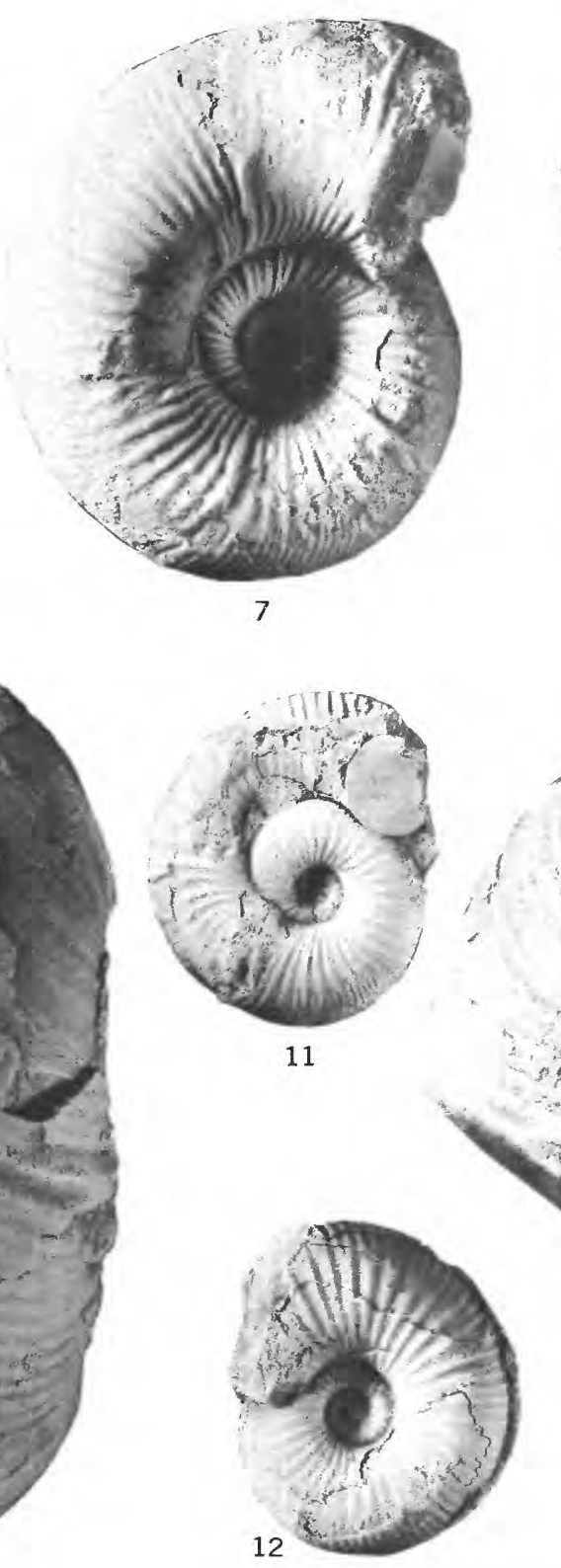

PROFESSIONAL PAPER 354 PLATE 13

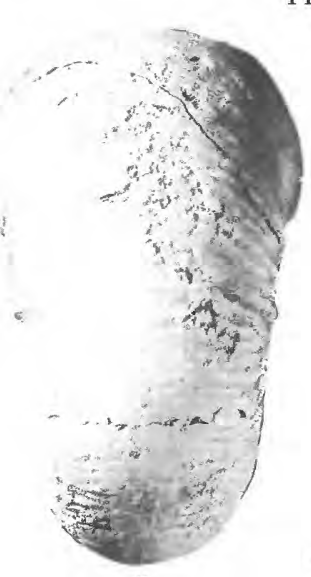

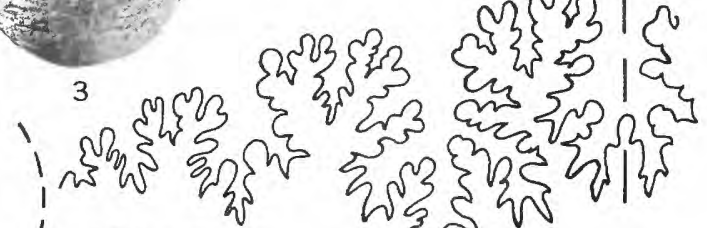

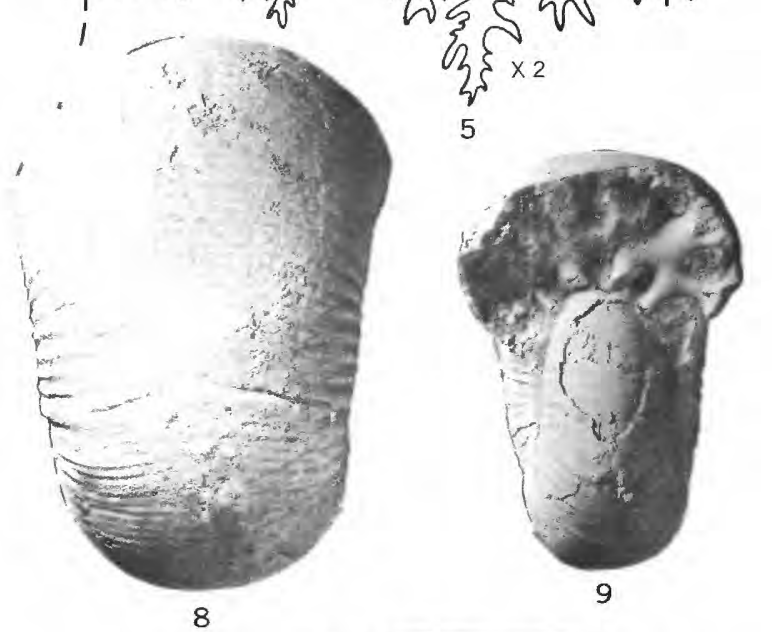

8

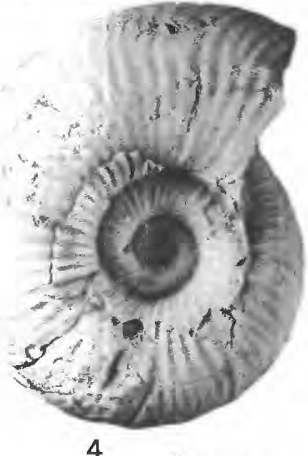

4

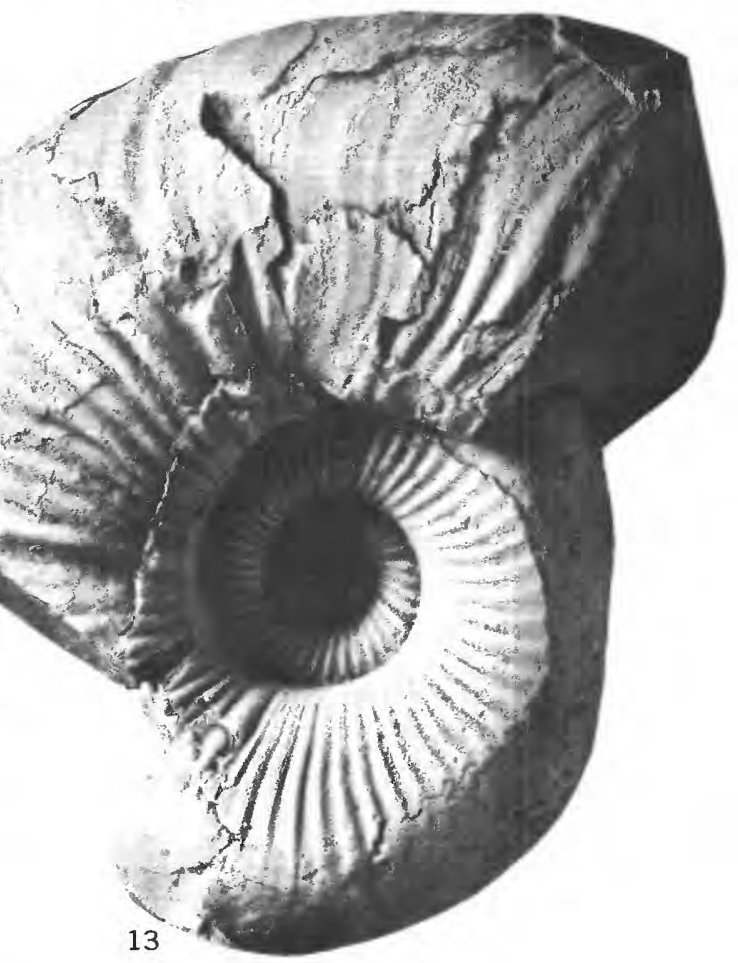

MOFFITITES ROBUSTUS 

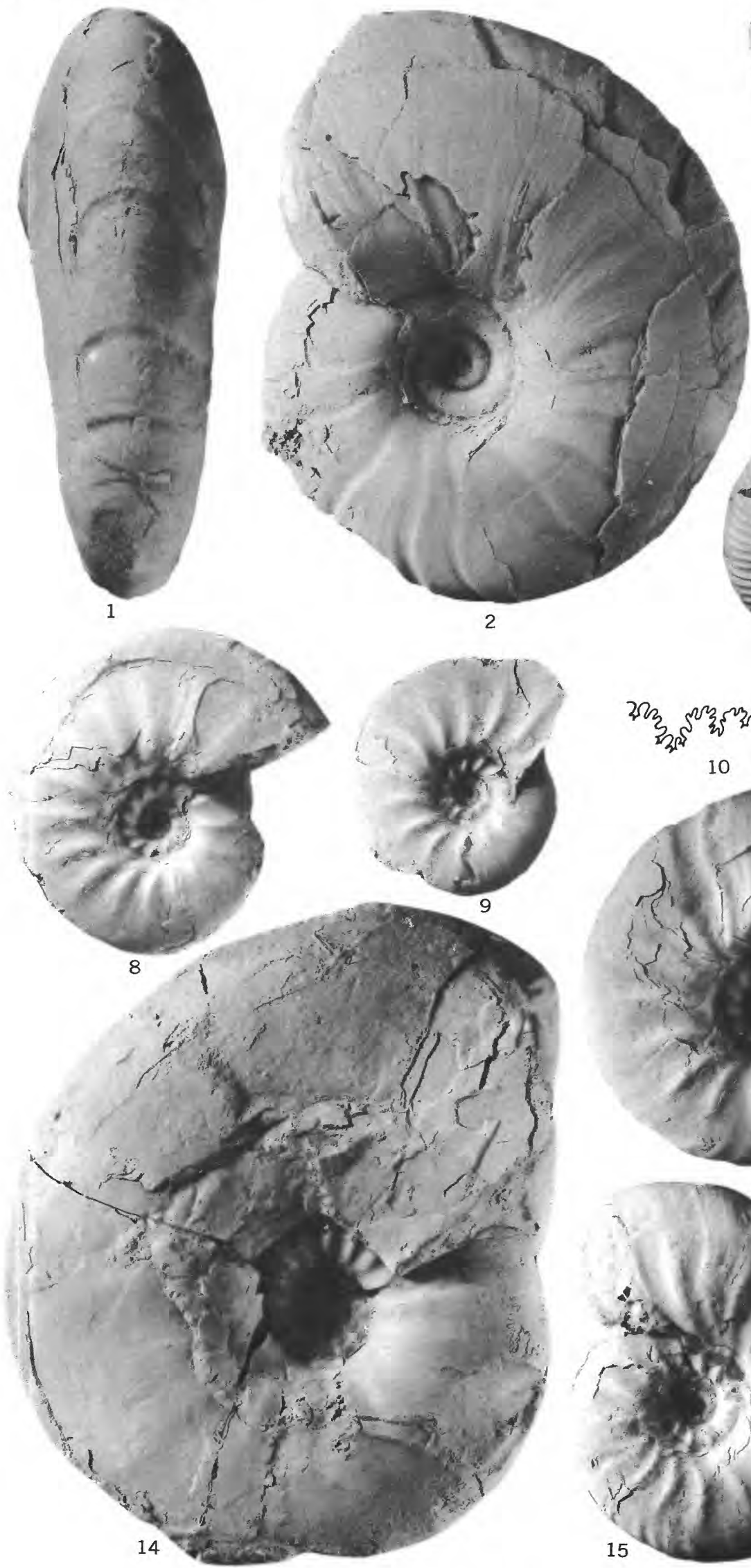
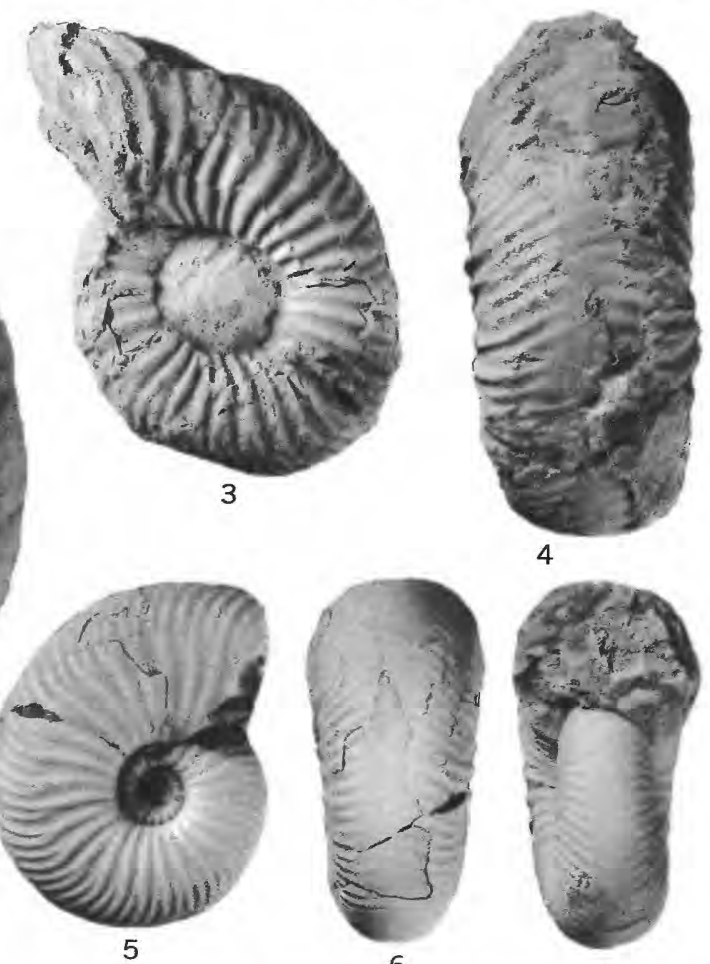
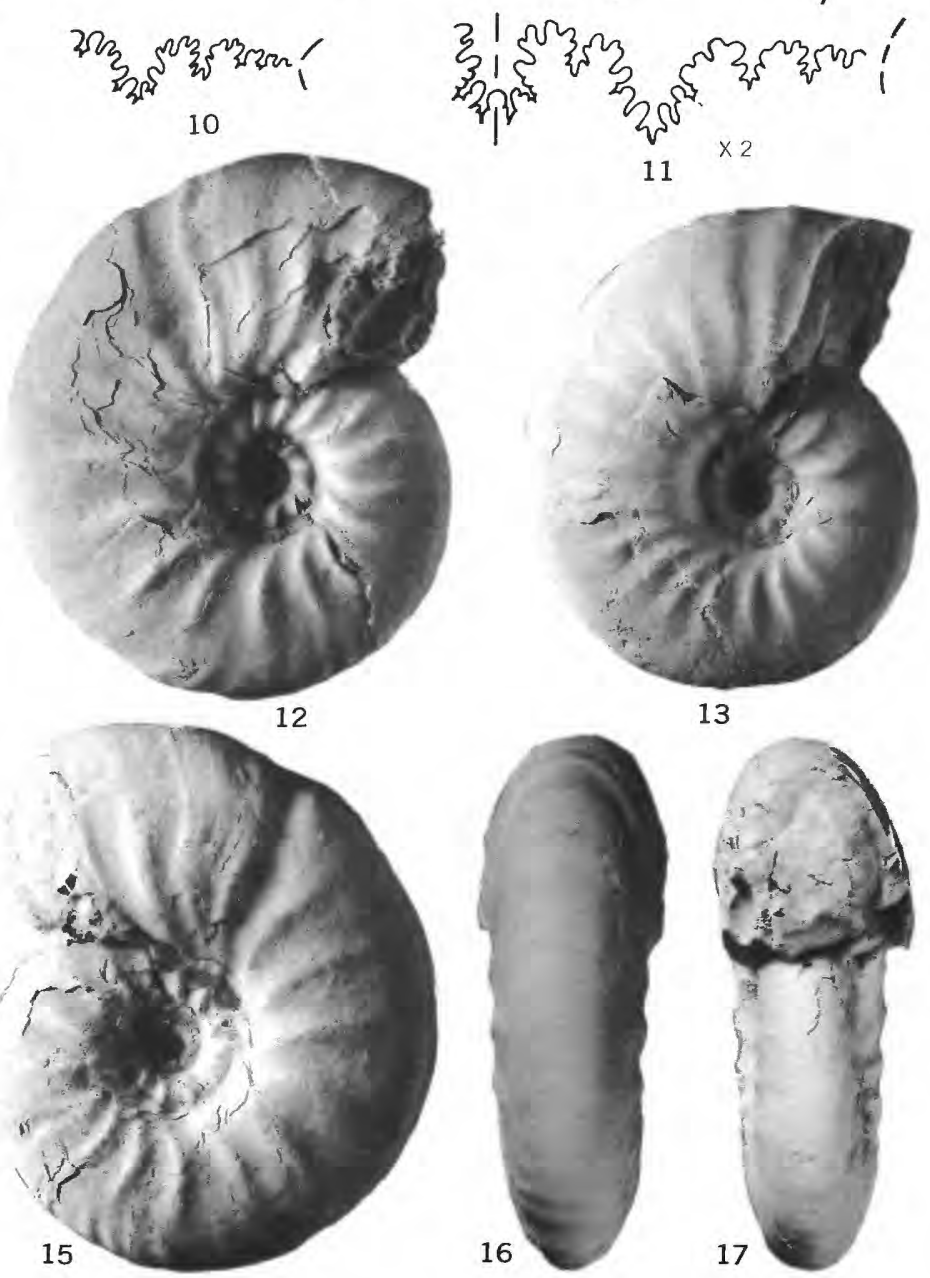

BEUDANTICERAS, MOFFITITES, AND FREBOLDICERAS 


\section{PLATE 14}

[Figures natural size unless otherwise indicated]

Figures 1, 2. Beudanticeras (Grantziceras) multiconstrictum Imlay (p. 105). Holotype USNM 128721, from USGS Mes. loc. 24877.

3-7. Moffitites, crassus Imlay, n. sp. (p. 102).

3, 4. Paratype USNM 130176, from USGS Mes. loc. 14487.

5-7. Holotype USNM 130175, from USGS Mes. loc. 8878.

8-17. Freboldiceras singulare Imlay (p. 102).

All specimens from USGS Mes. loc., 24877.

8-10. Lateral views and suture line of paratype USNM 129869a.

11, 12, 15-17. Holotype USNM 129868. Note fine striations on shell. Suture line drawn at whorl height of 15 $\mathrm{mm}$.

13. Paratype USNM 129869b.

14. Paratype USNM 129869c. The smooth body chamber occupies about three-fifths of a whorl. 


\section{PLATE 15}

[Figures natural size unless otherwise indicated]

Figures 1-6. Kennicottia bifurcata Imlay (p. 103).

1-5. Holotype USNM 129870, from USGS Mes. loc. 9972. Suture line drawn at diameter of $63 \mathrm{~mm}$.

6. Paratype USNM 129871, from USGS Mes. loc. 8873. Shows furcation of ribs on inner whorls.

7-13. Kennicottia rugosa Imlay, n. sp. (p. 103).

7, 8, 11. Paratype USNM 130153a, from USGS Mes. loc. 14485.

9, 10. Paratype USNM 130153b, from USGS Mes. loc. 14485.

12, 13. Holotype USN M 130152, from USGS Mes. loc. 9489. 

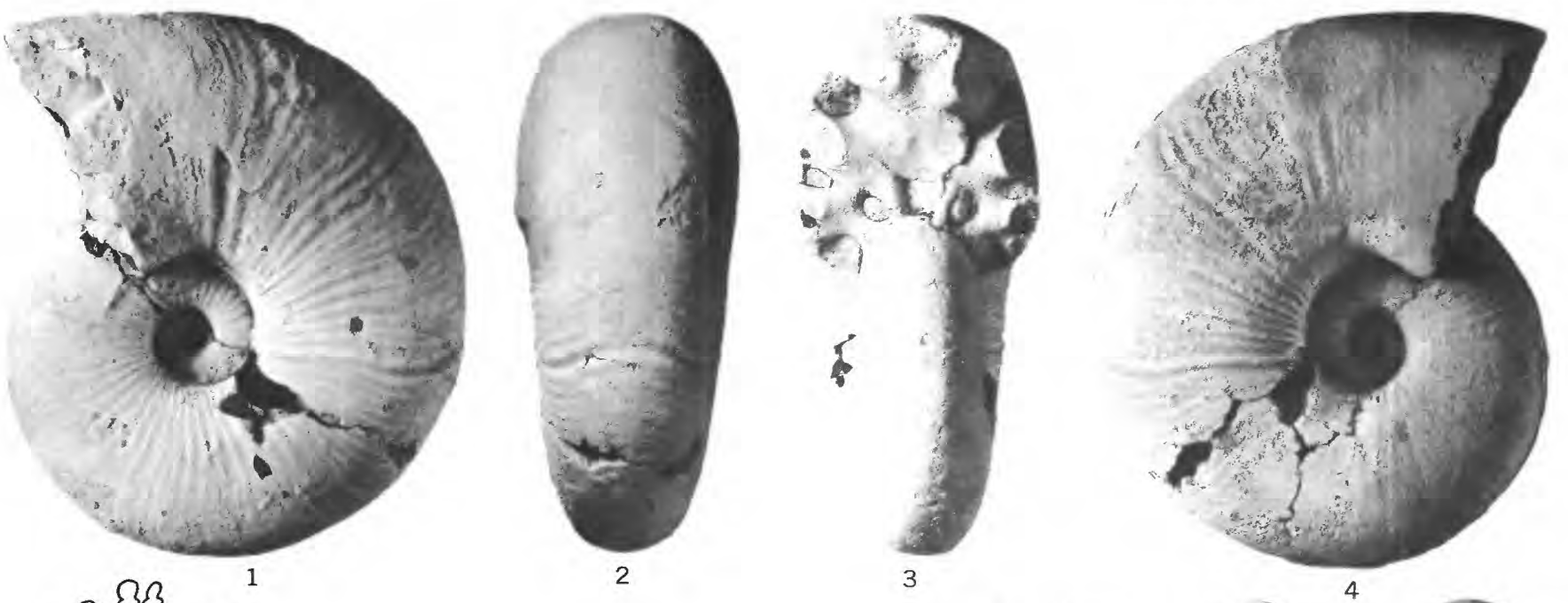

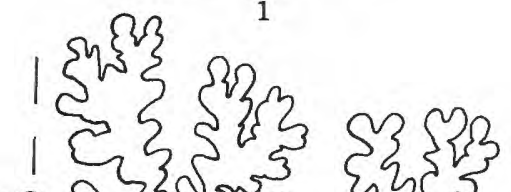

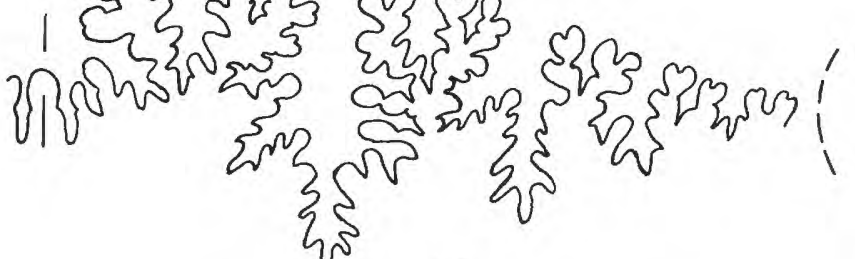
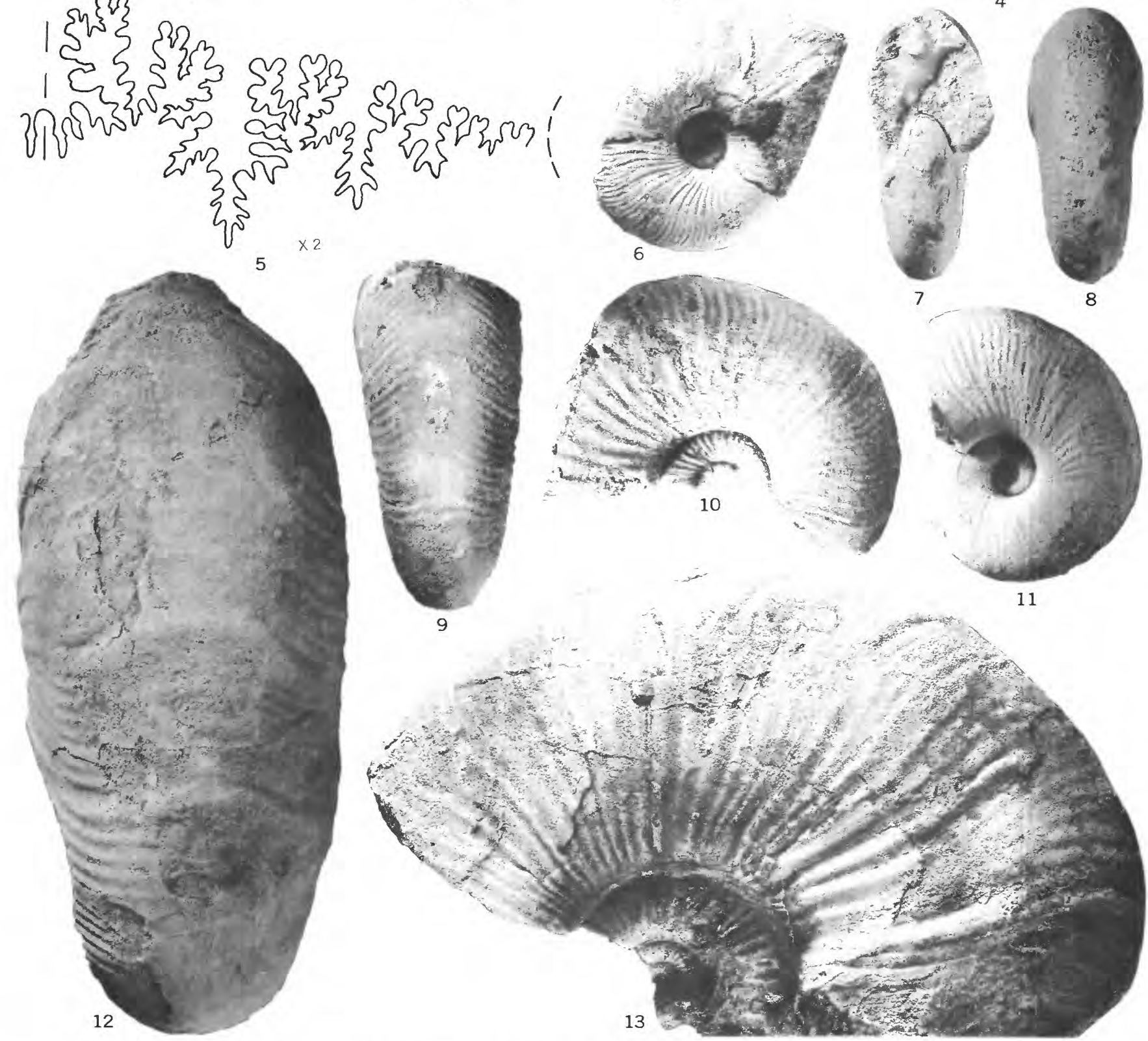

7

8

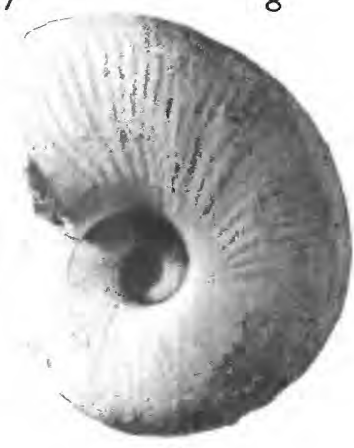

11

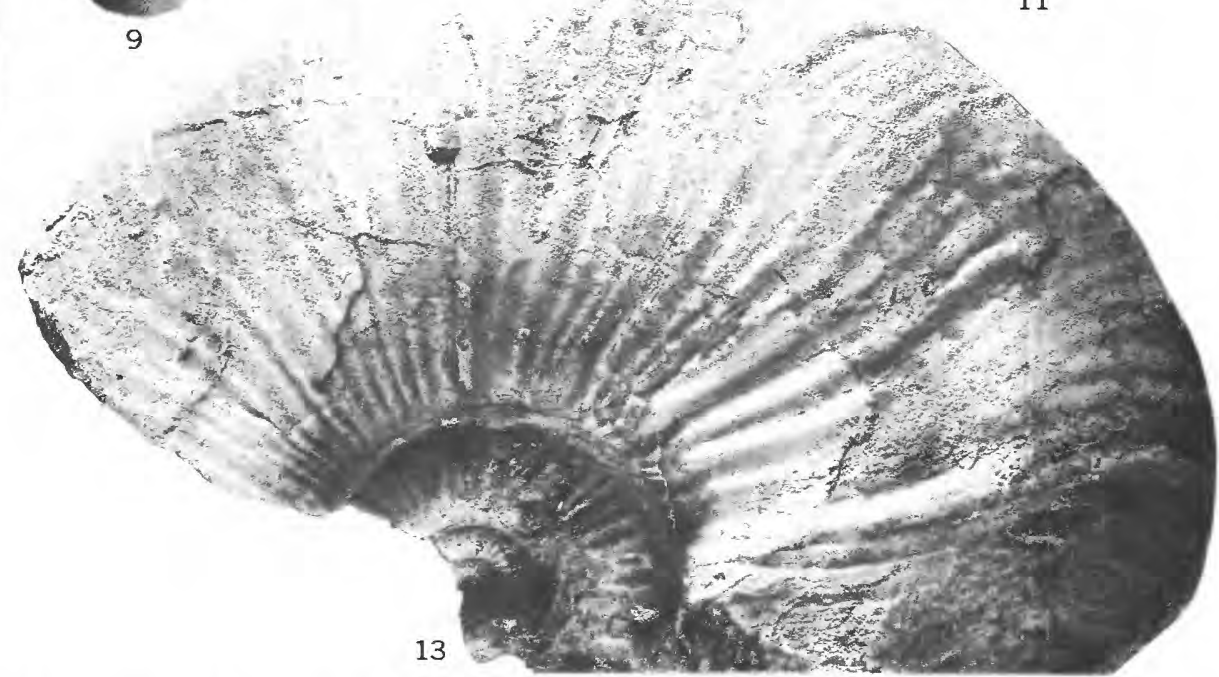

KENNICOTTIA BIFURCATA AND K. RUGOSA 

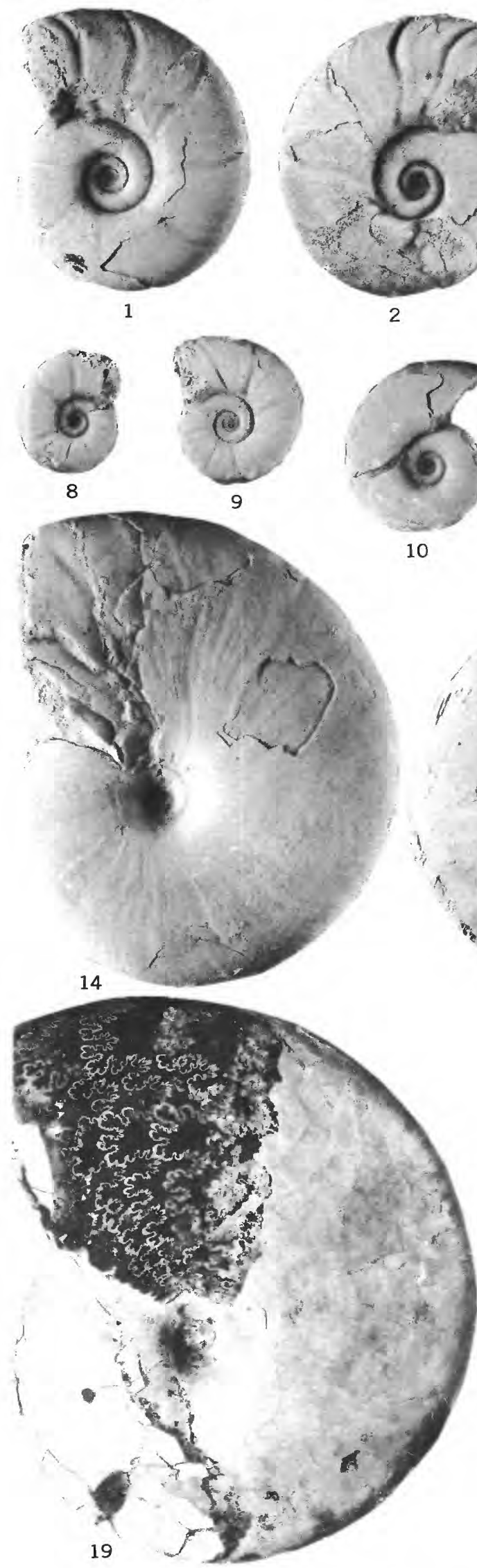
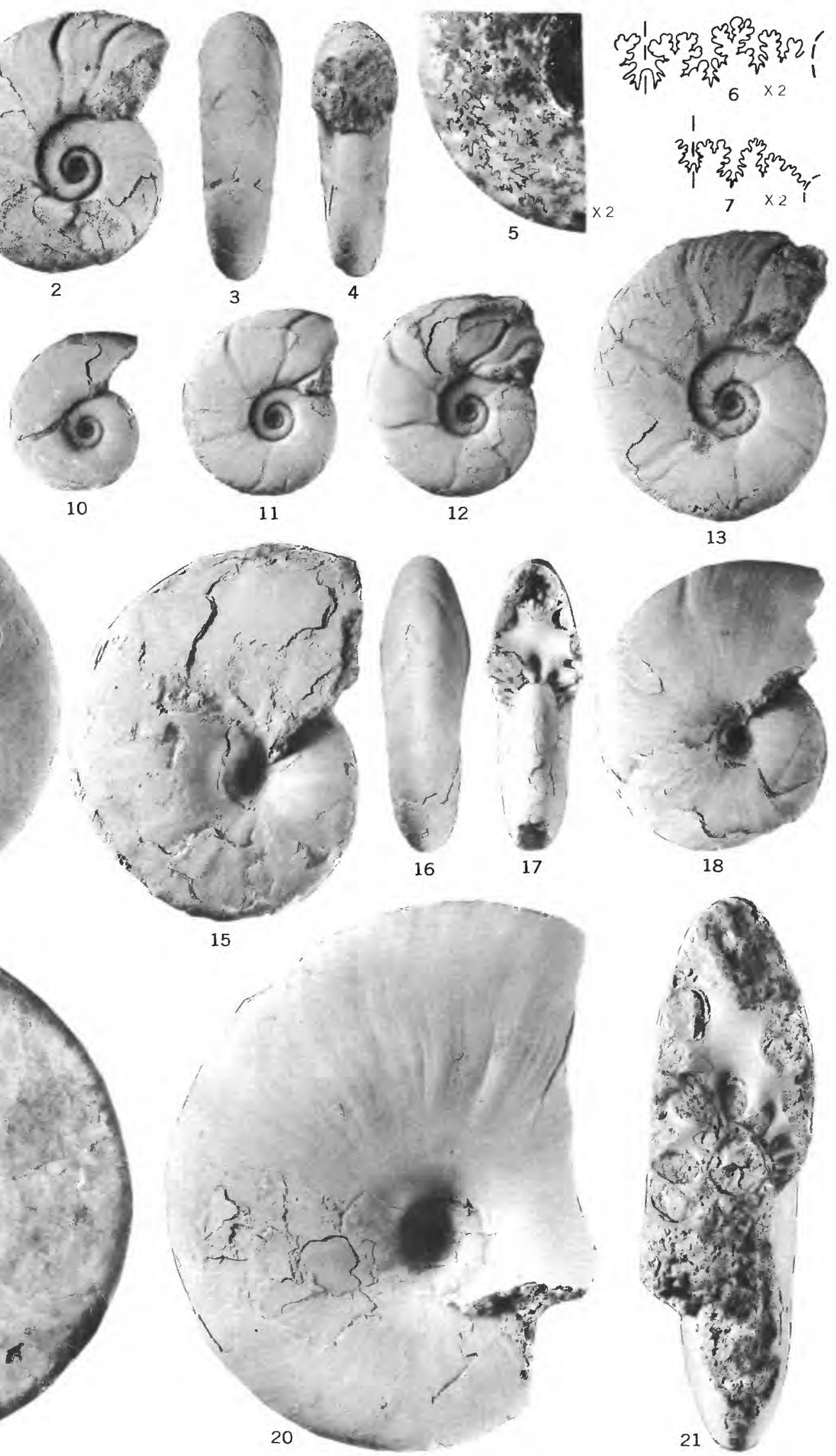


\section{PLATE 16}

[Figures natural size unless otherwise indicated]

Frgures 1-13. Puzosia aiaskana Imlay, n. sp. (p. 104).

1-4. Holotype USN M 130143, from USGS Mes. loc. 9492.

5-13. Paratypes USNM 130144, from USGS Mes. loc. 9492. Lateral views 8 to 13 shows differences in strength of ribbing and in constrictions. The suture lines were drawn from the specimen shown in figure 5 .

14-21. Beudanticeras glabrum (Whiteaves) (p. 105).

Plesiotypes USNM 130149, from USGS Mes. loc. 24877. Figures 14 and 19 represent fairly smooth specimens. Figure 15 represents a specimen with large bulges or ribs. Figures 16 to 18 show prominent constrictions. Figures 20 and 21 represent a specimen that develops weak lateral bulges. All these specimens are septate. 


\section{PLATE 17}

[Figures natural size unless otherwise indicated]

Figures 1-4. Desmoceras? sp. juv. (p. 106).

Specimen USNM 130135, from USGS Mes. loc. 9492. Suture drawn at whorl height of $10 \mathrm{~mm}$.

5-10, 12, 13. Brewericeras breweri (Gabb) (p. 105).

Plesiotypes USNM 130133, from USGS Mes. loc. 9492. Figures 5-7 represent a typical specimen. Figure 8 illustrates feather structure on the septate part of the shell and likewise bears ribbing typical of the species. Figures 9 and 10 and figure 13 represent two specimens in which coarse ribbing appears at an earlier growth stage than is typical in the species. The suture line was drawn at the adapical end of the body chamber from the specimen shown on figures 5-7.

11, 14-16. Brewericeras ef. B. hulenense (Anderson) (p. 106).

11. Specimen USNM 130159, from USGS Mes. loc. 14514.

14-16. Specimens USNM 130130, from USGS Mes. loc. 9492. 
GEOLOGICAL SURVEY
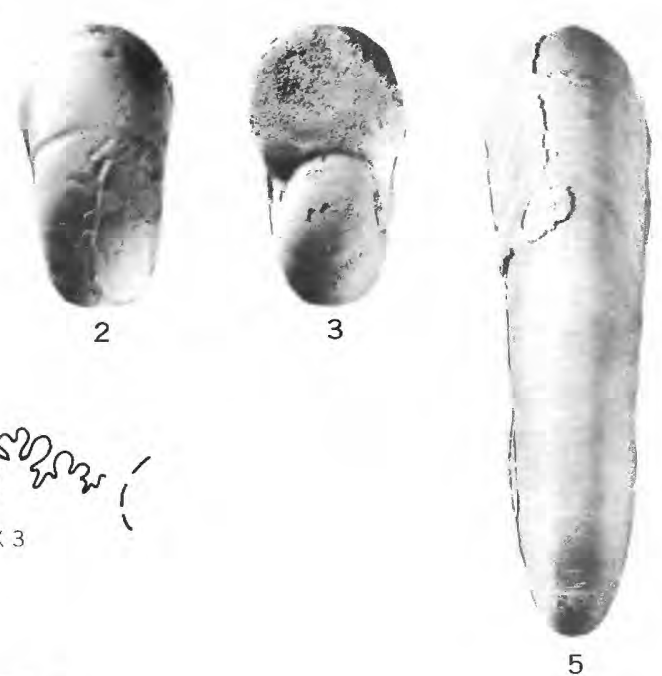

PROFESSIONAL PAPER 354 PLATE 17

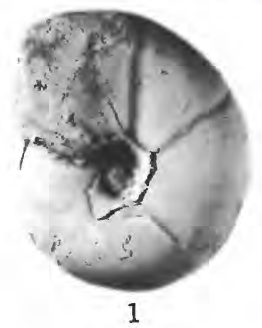

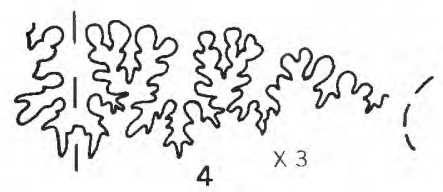
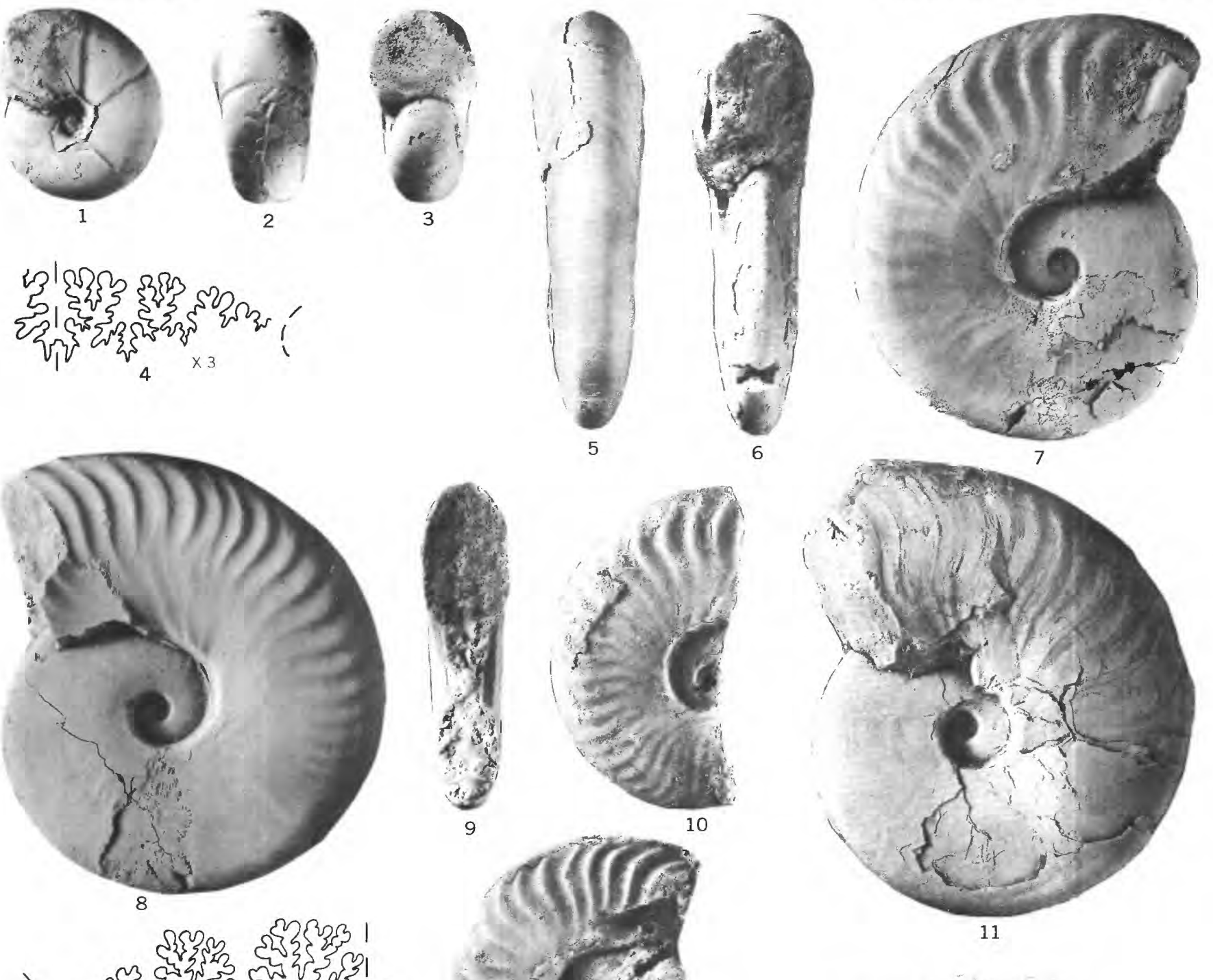

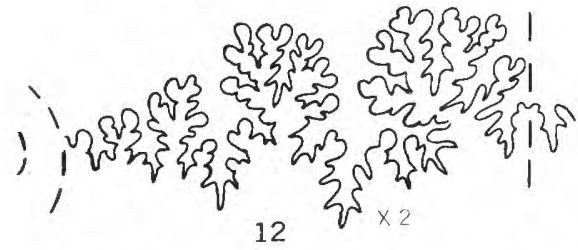
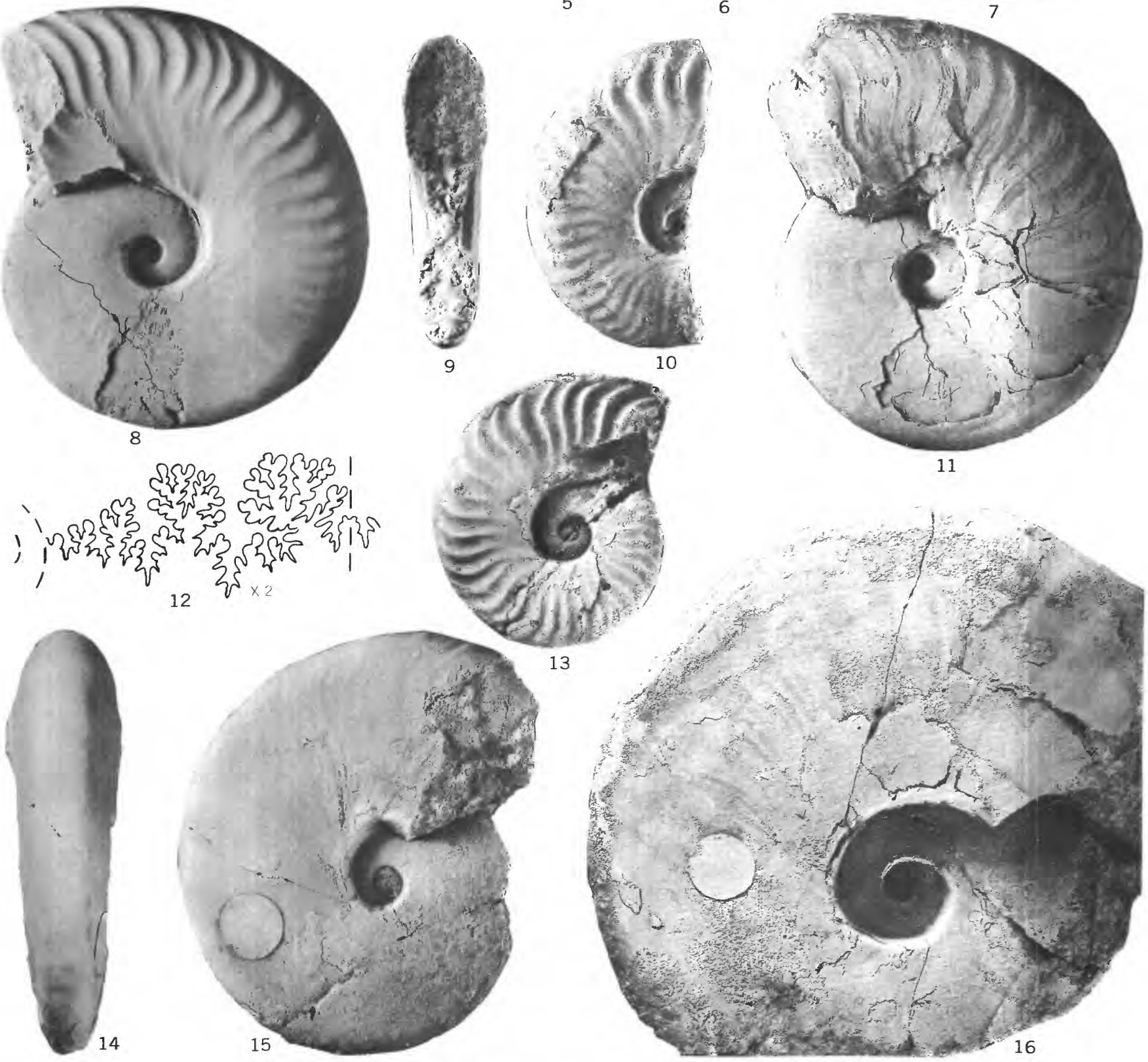

DESMOCERAS? SP., BREWERICERAS BREWERI, AND B. HULENSE 
GEOLOGICAL SURVEY

PROFESSIONAL PAPER 354 PLATE 18
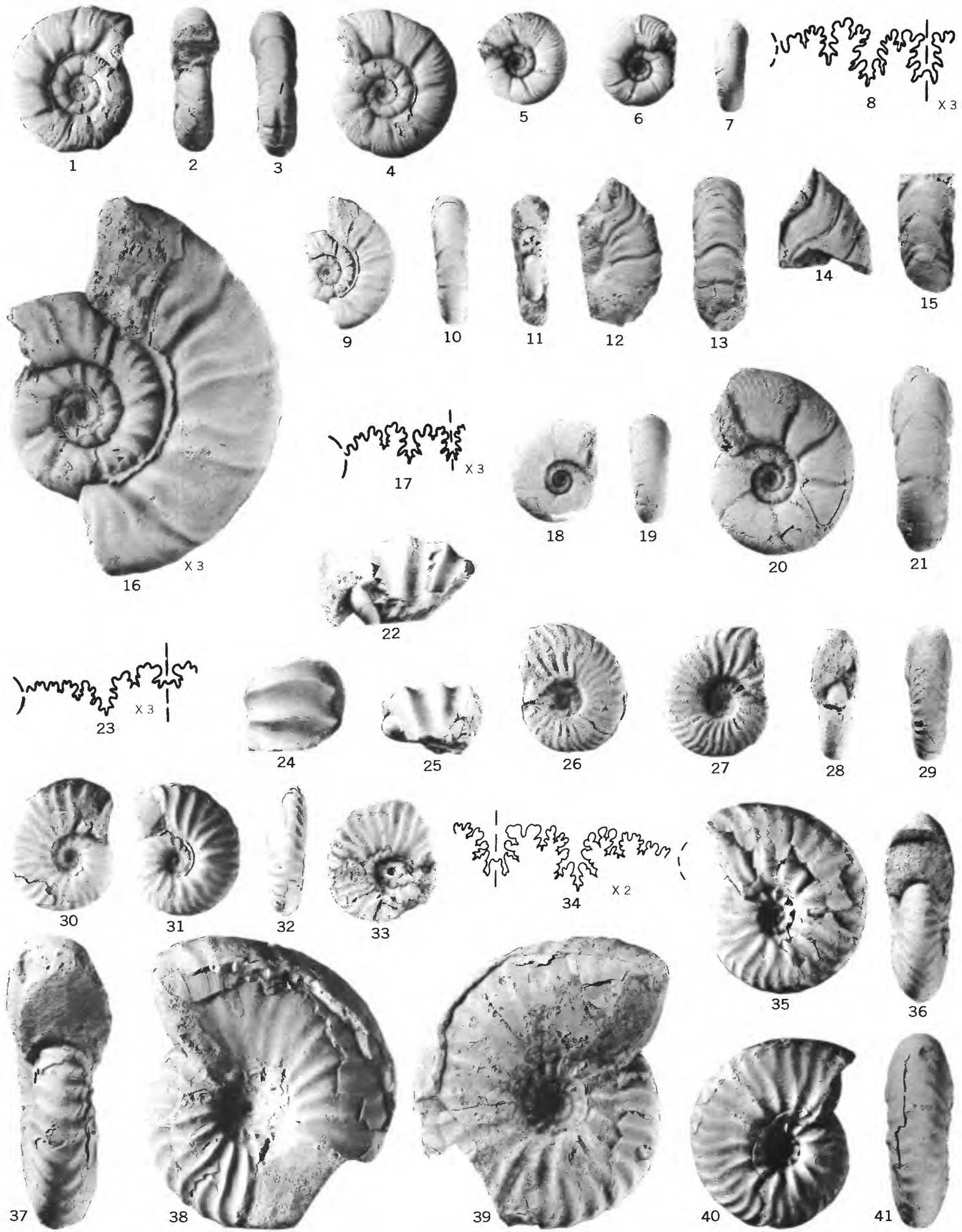

PARASILESITES, HULENITES, ARCTHOPLITES?, AND LEMUROCERAS 


\section{PLATE 18}

[Figures natural size unless otherwise indicated]

Figures 1-8. Parasilesites bullatus Imlay (p. 106).

1-4, 8. Holotype USNM 129872, from USGS Mes. loc. 9492.

5-7. Paratype USNM 129873, from USGS Mes. loc. 9492.

9-17. Parasilesites irregularis Imlay, n. sp. (p. 107).

All types are from USGS Mes. loc. 9492.

9-11, 16, 17. Lateral, ventral, and apertural views and suture line of holotype USNM 130147 . Suture line drawn at diameter of $13 \mathrm{~mm}$. Note that figure 16 is an enlargement of figure 9 .

12, 13. Paratype USNM 130148a.

14, 15. Paratype CSNM 130148b.

18-21. Hulenites of. H. reesidei (Anderson) (p. 107).

Specimens USNM 130134, from USGS Mes. loc. 9492.

22, 24, 25. Arcthoplites? sp. (p. 111).

Specimen USNM 130137, from USGS Mes. loc. 9492. Figures 24 and 25 represent ventral and lateral views of one specimen.

23, 30-33. Lemuroceras (Subarcthoplites) aff. L. belli McLearn (p. 111).

Both specimens from USGS Mes. loc. 14484.

23, 30-32. Specimen USNM 130136a. Suture line drawn at diameter of $19 \mathrm{~mm}$.

33. Specimen USNM 130136b.

26-29. Lemuroceras? sp. juv. ef. L. dubium Collignon (p. 110). Specimen USNM 130157, from USGS Mes. loc. 14484.

34-41. Lemuroceras talkeetnanum Imlay, n. sp. (p. 109).

34, 37-39. Holotype USNM 130151, from USGS Mes. loc. 24877. Suture line drawn at whorl height of $14 \mathrm{~mm}$. 35, 36, 40, 41. Paratype USNM 130150, from USGS Mes. loc. 24877. 


\section{PLATE 19}

[Figures natural size unless otherwise indicated]

Figures 1-3. Leconteites lecontei (Anderson) (p. 109).

Plesiotype USNM 130171, from gulch emptying into Hulen Creek a little east of Ono, Calif. Inserted for comparison with species of Leconteites from Alaska. Note tubercles at umbical edge.

4-6. Leconteites modestus (Anderson) (p. 109).

4, 5. Plesiotypes USNM 130172, from USGS Mes. loc. 9971.

6. Plesiotype USNM 130173, from USGS Mes. loc. 11389.

7-14. Leconteites deansi (Whiteaves) (p. 109).

7, 8. Plesiotype USNM 130164a, from USGS Mes. loc. 9972.

12-14. Plesiotype USNM 130164b, from USGS Mes. loc. 9972 . Suture line drawn at whorl height of $10.5 \mathrm{~mm}$. 9-11. Plesiotype USNM 130170, from USGS Mes, loc. 2201.

15-27. Leconteites cf. L. deansi (Whiteaves) (p. 109).

15, 20, 21. Specimen USNM 130162a, from USGS Mes. loc. 9972.

16, 17. Specimen USNM 130158, from USGS Mes. loc. 14484.

18. Specimen USNM 130169, from USGS Mes. loc. 2201.

19, 23, 24, 27. Four specimens USNM 130174, from USGS Mes. loc. 8872. These show changes in ribbing during growth.

22. Specimen USNM 130162b, from USGS Mes. loc. 9972.

25, 26. Specimen USNM 130162c, from USGS Mes. loc. 9972.

28-32. Aucellina sp. (p. 91).

Both specimens from USGS Mes. loc. 8873

28-30 Left and right valves and anterior view of both valves of an average-sized specimen, USNM $130167 \mathrm{a}$.

31,32 Left and right valves of a large specimen, USNM $130167 \mathrm{~b}$.

33-35 Puzosigella cf. P. rogersi (Hall and Ambrose) (p. 108).

Three specimens USNM 130168, from USGS Mes. loc. 8877, show changes in ribbing during growth.

36-39 Cleoniceras overbecki Imlay, n. sp. (p. 108).

Holotype USNM 130141, from USGS Mes. loc. 9492. Note elongate tubercles at umbilical edge. 
GEOLOGICAL SURVEY

PROFESSIONAL PAPER 354 PLATE 19
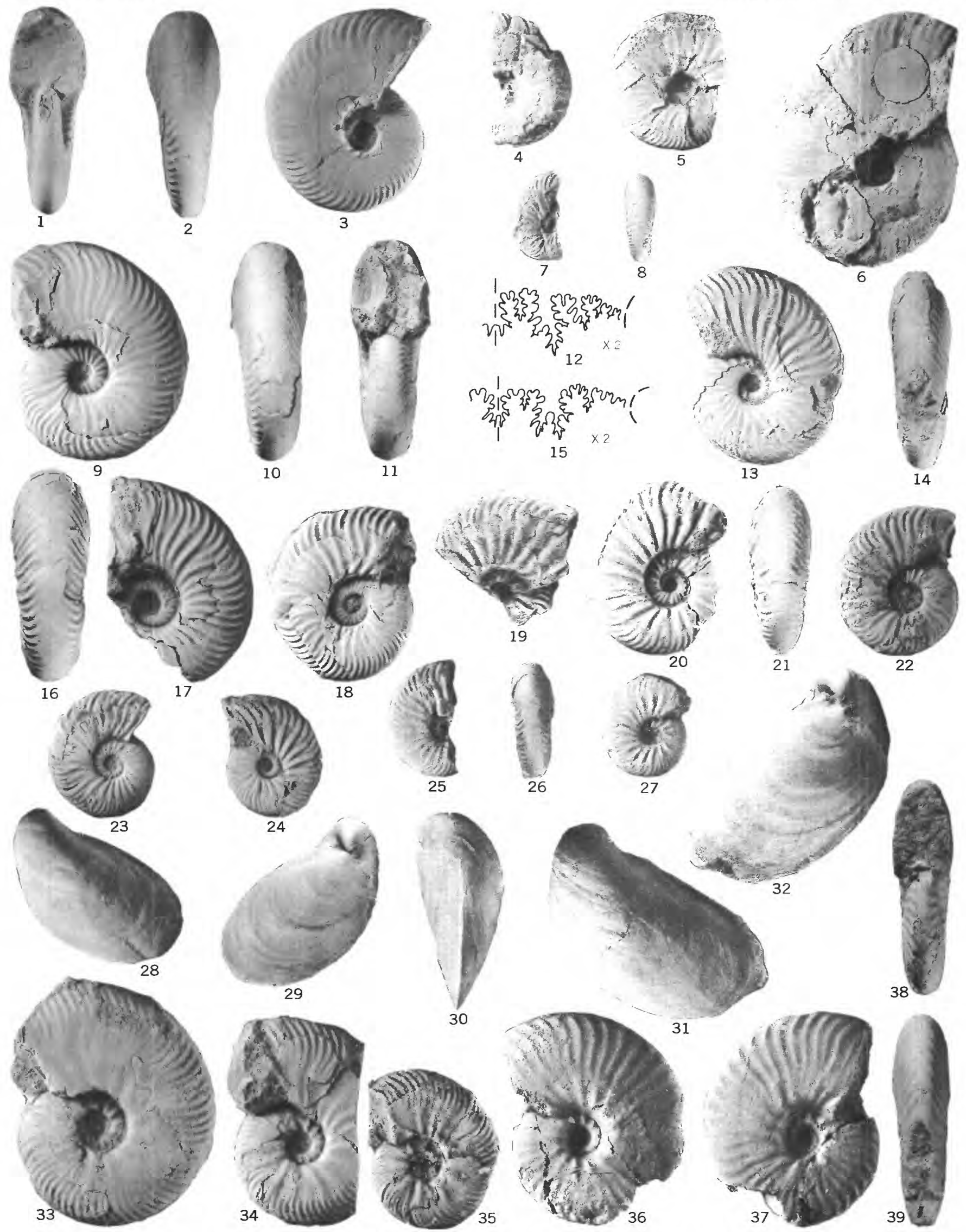

14
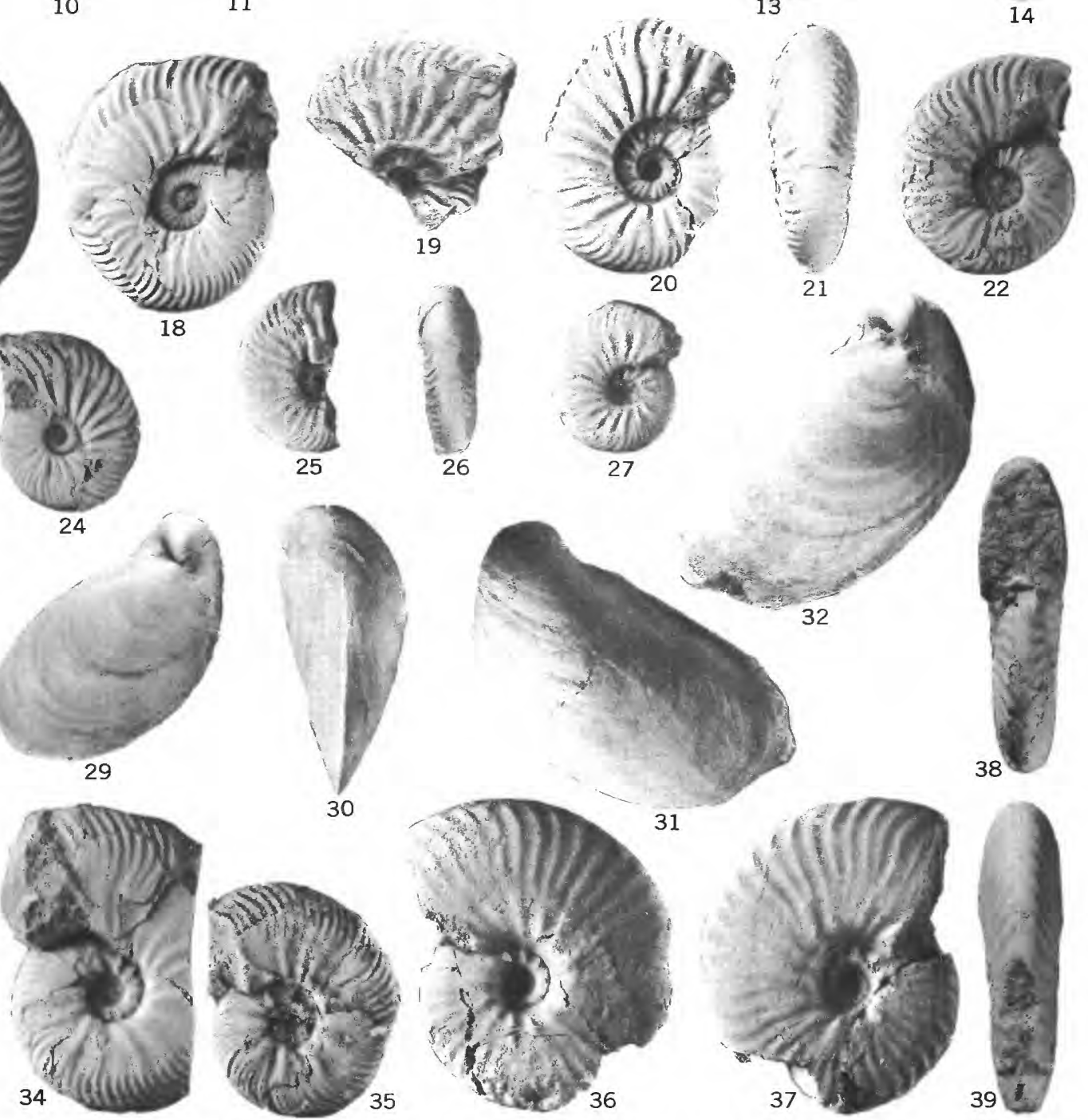

LECONTEITES, AUCELLINA, PUZOSIGELLA, AND CLEONICERAS 